\title{
El Registro Arqueológico en el territorio de Cangas de Onís (Principado de Asturias): Producciones cerámicas tardías y altomedievales
}

\section{Archaeological Survey in Cangas de Onís (Principality of Asturias): Late roman and early medieval pottery}

O. REQuejo PAgÉs

\begin{abstract}
RESUMEN
En este trabajo abordamos el estudio de un conjunto cerámico procedente de diversos yacimientos del territorio de Cangas de Onís (Principado de Asturias). El objetivo principal es el análisis de los procesos técnicos, y su influencia sobre las propiedades físicas de la cerámica.

Este estudio, combinado con criterios estratigráficos, nos permite identificar diferentes grupos productivos y establecer su evolución cronológica.
\end{abstract}

PALABRAS CLAVE

Cerámica, procesos técnicos, Asturias, Cangas de Onís

\section{ABSTRACT}

This paper introduces a report of a group of pottery coming from different sites in Cangas de Onís, territory of the ancient Asturias Kingdom. The main objective is the study of the technical processes and their influence in physical properties of the pottery. This study, combined with stratifies criteria, allowed us to set different production groups and establish a chronological evolution frame.

\section{KEY WORDS}

Pottery, technical processes, Asturias, Cangas de Onís 


\section{INTRODUCCIÓN}

Se presentan los materiales cerámicos procedentes de cinco yacimientos arqueológicos de naturaleza diversa, localizados en el sector oriental de la región, en el concejo de Cangas de Onís (fig. 1).

Los yacimientos se documentaron, en unos casos, en el transcurso de trabajos de prospección realizados en la zona y, en otros, como resultado de actuaciones arqueológicas ejecutadas en relación con obras de infraestructura o restauración. De cada uno de ellos se detallan los trabajos realizados, los resultados y valoraciones histórico-arqueológicas así como una relación bibliográfica precisa. Se hace especial incidencia en el análisis de los procesos técnicos implicados en la producción cerámica así como los conceptos y criterios utilizados para la descripción y clasificación de los materiales para, seguidamente, caracterizar las distintas producciones cerámicas.

Finalmente, se exponen las conclusiones inferidas del estudio y análisis del conjunto de los materiales cerámicos.
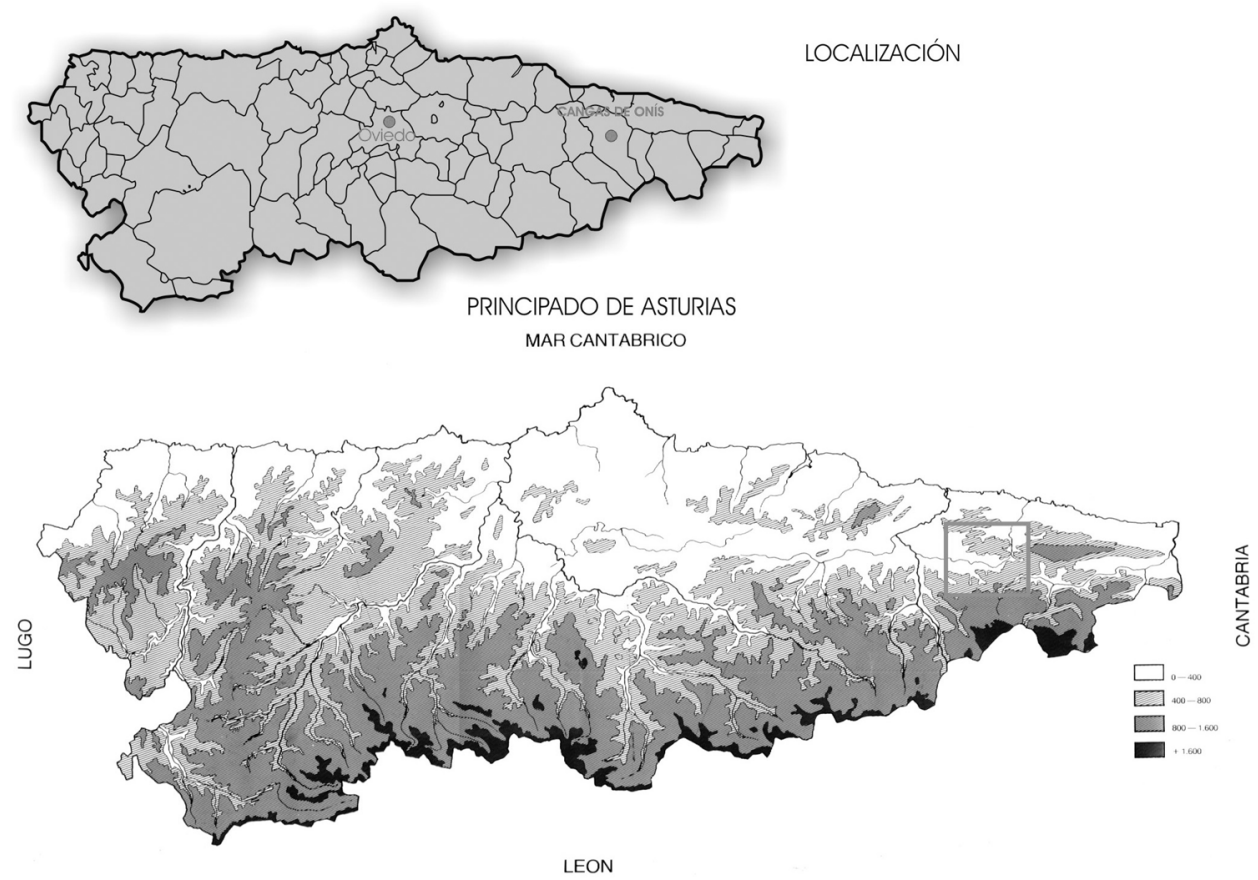

Fig. 1. Localización de la zona de estudio: Cangas de Onís. 


\section{LOS CONTEXTOS ARQUEOLÓGICOS}

El nexo de unión de los yacimientos estudiados —además de su localización geográfica-, son los materiales cerámicos documentados en los niveles de ocupación más antiguos y que presentan una uniformidad técnica y formal que remite a momentos del Alto Medievo, entre los siglos VIII y X (fig.2).

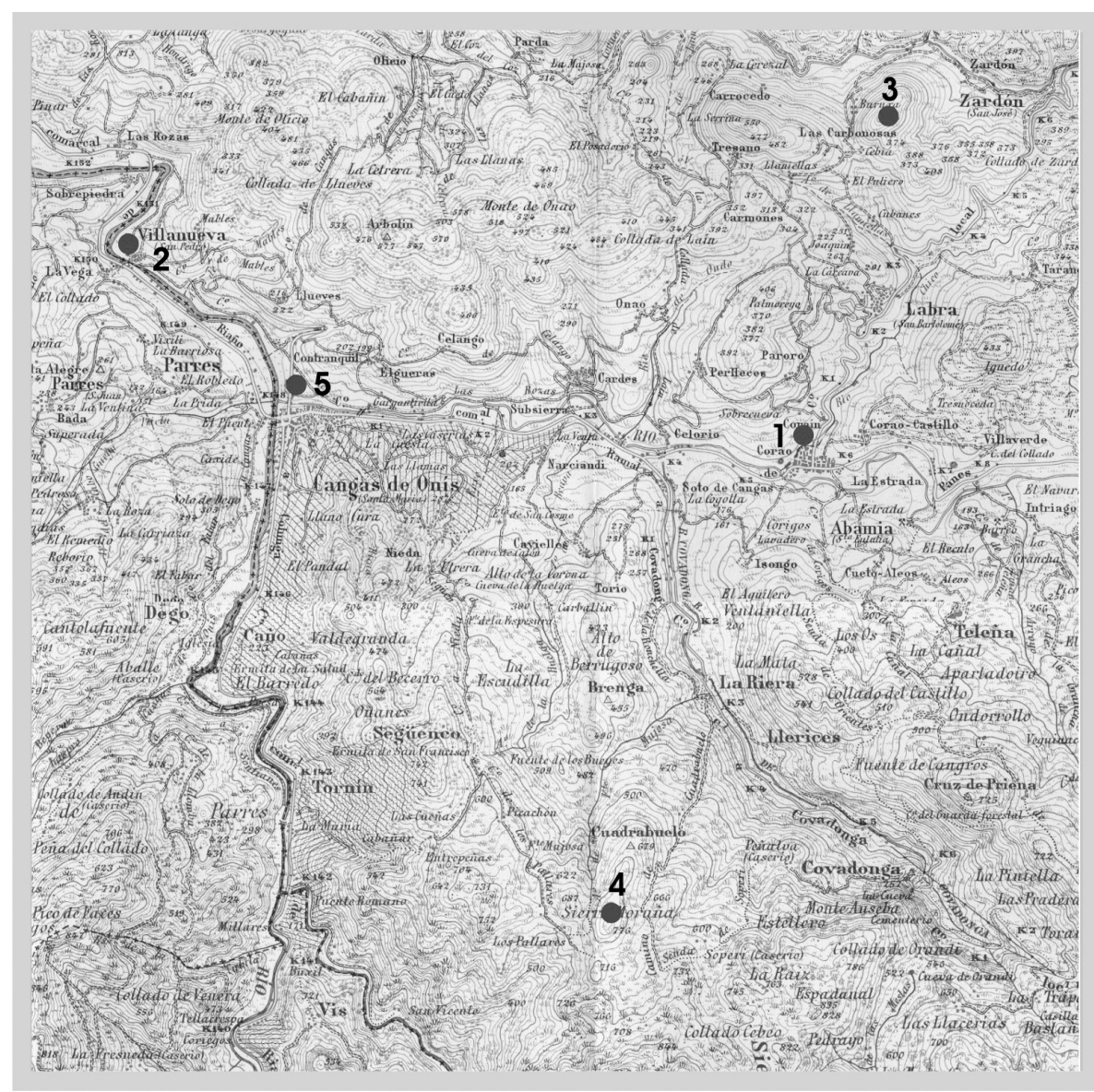

\section{1.- VEGA DE CORAO}

2.- SAN PEDRO DE VILLANUEVA

3.- TORRE DE PEÑE MANIL

4.- TORRE DE PORRA PORTIELLA

\section{5.- NECRÓPOLIS DE SANTA CRUZ}

Fig. 2. Localización de los yacimientos arqueológicos. 1.-Restos constructivos de la vega de Corao (Co), Corao, Cangas de Onís. 2.-Monasterio de San Pedro de Villanueva (SPV), Cangas de Onís. 3.-Torre de Peñe Manil (PM), Cebia, Cangas de Onís. 4.-Torre de la Porra (LP), Següenco, Cangas de Onís. 5.-Necrópolis de Santa Cruz (SC), Vega de Contranquil, Cangas de Onís. 


\subsection{Vega de Corao (Corao, Cangas de Onís)}

Corao se localiza en el valle del río Güeña que discurre al Sur del pueblo. En esta vega se ha identificado un importante número de yacimientos arqueológicos de diferentes periodos cuya concentración debe ponerse en relación con las óptimas condiciones de habitabilidad que dicha comarca ofrece ${ }^{1}$. El yacimiento medieval se localiza en el extremo noroccidental del pueblo, en la vertiente norte de Río Chico, afluente del Güeña.

En el año 1988 durante el transcurso del seguimiento arqueológico de las obras de construcción de la variante de Corao, la limpieza de los cortes abiertos por la caja de la nueva carretera en la finca conocida como de San Nicolás sacó a la luz evidencias de una ocupación medieval con abundantes restos de cerámicas y muros - muy arrasados-correspondientes a varias estructuras de hábitat en llano?

Las evidencias arqueológicas, puestas de manifiesto gracias a los sondeos arqueológicos previos, plantearon la conveniencia de realizar una excavación arqueológica de urgencia de cierta extensión entre los puntos kilométricos 6+200 y 6+240 así como una prospección electrofísica ${ }^{3}$.

Se identificaron un total de tres estructuras de habitación formadas por mampuestos de cantos rodados de cuarcita y aisladamente de calizas cretácicas, trabados con arcilla y asentados directamente sobre el nivel aluvial del sustrato (fig. 3 y 4 ).

\section{Estratigrafía}

\section{I- Capa de tierra vegetal}

II- Capa de matriz arenosa con componente vegetal y color rojizo (escasos materiales cerámicos)

1 Los yacimientos abarcan desde el Paleolítico hasta época medieval: al primer periodo corresponden los abrigos de "Jondrigu» y el yacimiento al aire libre de "La Cavada»; los restos de época megalítica tienen su expresión en el desaparecido Dolmen de Abamia, y las cuevas del Cuélebre y de Trespando hacen referencia a la ocupación humana de la Edad del Bronce. En época romana hay que destacar la veintena de lápidas vadinienses encontradas en esta zona y, por último, completando la secuencia arqueológica, los restos documentados en la finca de San Nicolás dan testimonio de la ocupación medieval en la vega de Corao.

${ }^{2}$ Los restos se descubrieron con motivo del Proyecto de ampliación de la carretera AS-114 Cangas de Onís - Panes, tramo: nuevo trazado Cangas de Onís Benia (PK 5+900 - 6+600). Obras promovidas por la Consejería de Obras Públicas del Principado. Las Excavaciones y el control arqueológico de las obras fue realizado por el Gabinete Arqueológico integrado en aquel momento (1988) por G. Adán, C. Cabo, R. Estrada, A. Martínez. O. Requejo y A. Villa.

${ }^{3}$ El estudio electrofísico - realizado por el equipo de la Escuela de Ingenieros de Minas dirigido por el Catedrático D. Modesto García-, ofreció diversos puntos de elevada resistividad y en esas zonas se procedió a abrir nuevos sondeos para comprobar si coincidían con nuevas estructuras, siendo el resultado altamente positivo. 
El Registro Arqueológico en el territorio de Cangas de Onís (Principado de Asturias)...
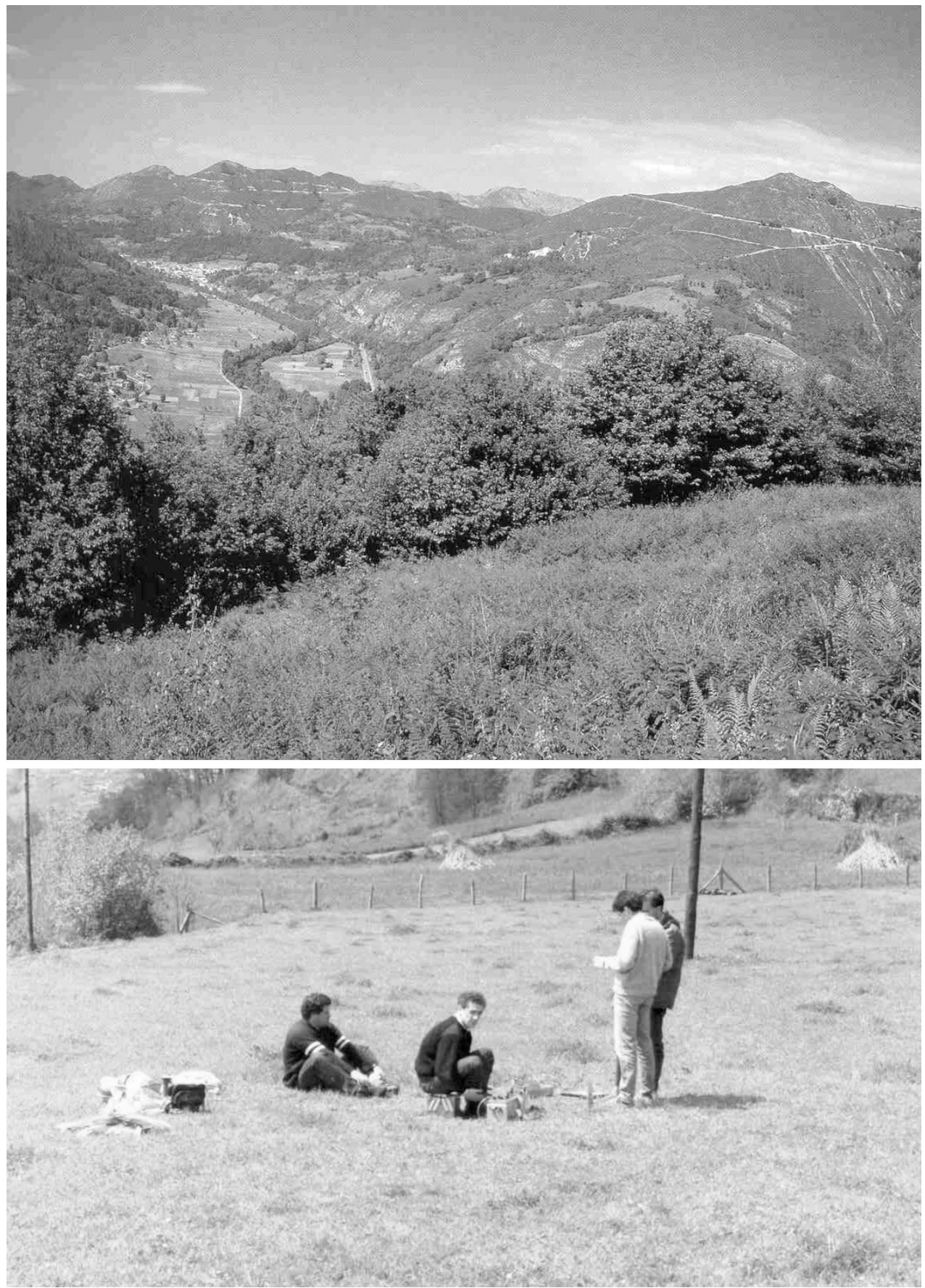

Fig. 3. 1. Vista de la Vega del río Sella. 2. Finca de San Nicolás, en la Vega de Corao. Prospección electrofísica 


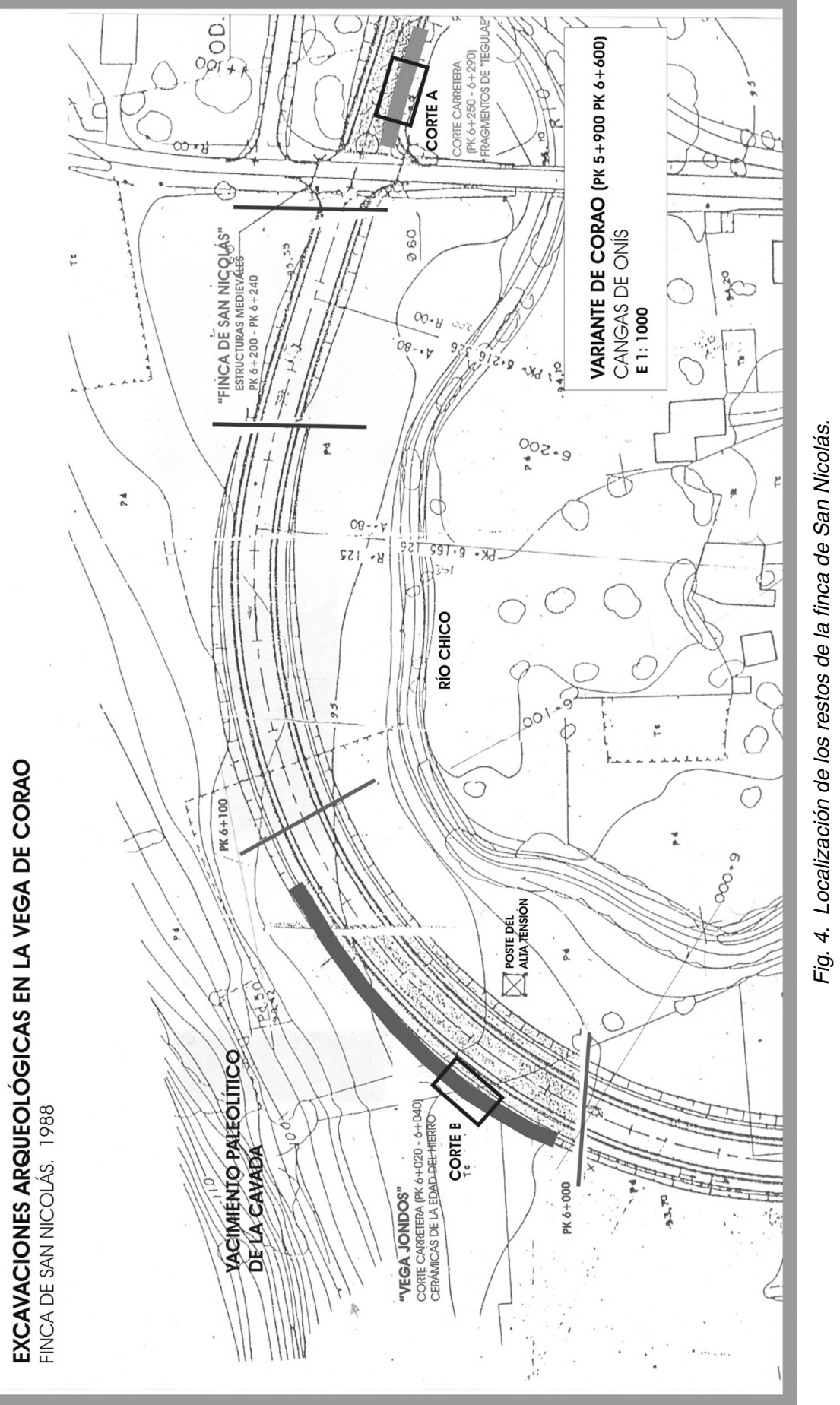




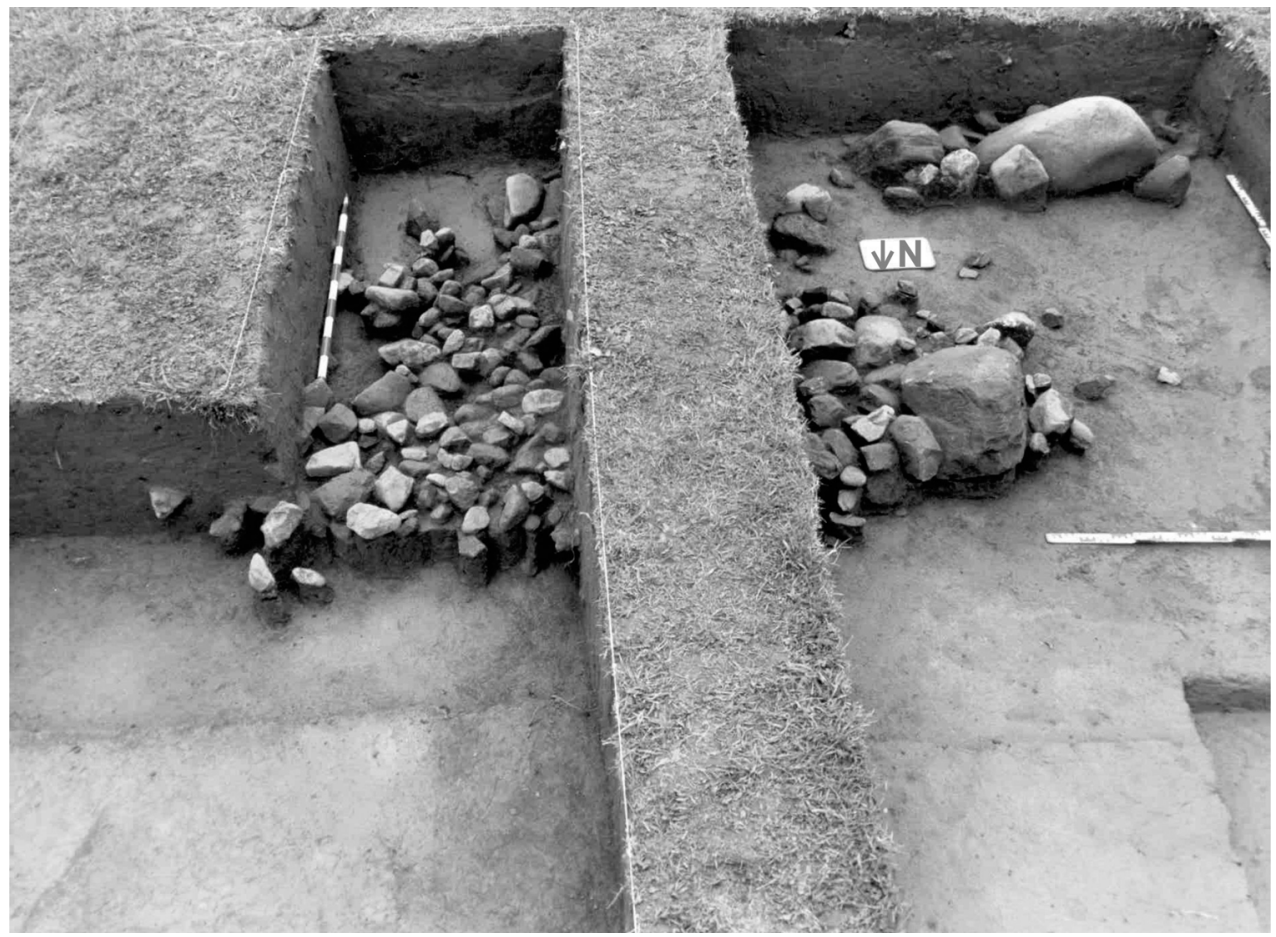

Fig. 5. Vega de Corao: estructura de cantos $n .^{\circ} 3$.

III-Nivel de matriz arcillosa marronácea, con abundantes materiales cerámicos, sellado en la parte superior por una capa de tejas y materiales constructivos (nivel de derrumbe/amortización de la estructura).

IV-Estructura: cimentaciones y suelo de ocupación asociado: capa de matriz terrosa-arcillosa y color oscuro con abundantes restos cerámicos

V-Restos de un muro anterior arrasado (únicamente se ha documentado en la estructura n. $\left.{ }^{\circ} 3\right)$.

VI-Nivel de aluvión: capa arenosa de color amarillento con cantos de pequeño tamaño sobre la que se asientan las estructuras (fig. 5).

Además, el registro y estudio de los cortes abiertos para la caja del nuevo trazado proporcionaron interesantes hallazgos en otros puntos de la vega: así, el Corte A, en el extremo Este de la vega (PK 6+250-6+290 y cota -030m) proporcionó

4 El argumento para atribuir a este monarca la fundación del Monasterio era una antigua escritura de donación otorgada el 21 de Febrero del año 746 y actualmente desaparecida: se cree que el obispo de Pamplona e historiador, Fr. Prudencio Sandoval, se habría llevado de Villanueva la citada escritura para componer su Crónica de los Cinco Obispos no volviendo a tenerse noticias de su paradero. Otra razón para considerarlo de fundación real se basaba en la celebración periódica de misas por los reyes fundadores y también cabe la posibilidad de que la capilla de San Miguel, situada a los pies del actual templo, pudiera haber sido originariamente panteón real (Manzanares Rodríguez, J., 1955). 
fragmentos de «tegulae» en el nivel III (capa de matriz arcillosa y tonalidad rojiza), mientras en el sector Oeste (al pie del yacimiento paleolítico de La Cavada), el Corte B (PK 6+020-040 y cota - 060- 080 m) documentó en el nivel III (capa de matriz rojiza, arcillosa, con cantos angulosos y rodados), una concentración de cerámicas de la Edad del Hierro. Todo ello evidencia la dilatada y cualitativa secuencia ocupacional de la vega de Corao.

\section{Bibliografía}

Gabinete Arqueológico, 1988.

Requejo Pagés, O., 1990.

\subsection{Monasterio de San Pedro de Villanueva (Villanueva, Cangas de Onís)}

El Monasterio de San Pedro de Villanueva se localiza a dos kilómetros de Cangas de Onís, en el valle del río Sella, a unos $100 \mathrm{~m}$ de su cauce, junto al pueblo de Villanueva.

Si bien algunos autores atribuían su fundación al monarca Alfonso I (739$757)^{4}$, a tenor de los restos materiales conservados, su antigüedad únicamente podía remontarse con cierta seguridad a principios del siglo XII.

Con motivo de las obras de restauración del Monasterio y su adaptación como Parador de Turismo, se realizaron cuatro fases de excavaciones arqueológicas $(1990,1995,1997$ y 2000) en diversos sectores del monumento y su entorno que aportaron datos novedosos sobre la cronología y evolución del yacimiento ${ }^{5}$.

Los hallazgos de mayor interés y relevancia se produjeron en la «Huerta del Cura» (un pequeño huerto detrás de las antiguas cocinas), y bajo el antiguo granero de Monasterio en el ala Oeste, el sector más próximo al cauce del río 6 . Los trabajos realizados en el yacimiento permitieron documentar restos de estructuras de habitación y defensivas encuadrables entre los siglos VIII/IX-X lo que permite confirmar un origen Altomedieval para San Pedro de Villanueva, validando y reforzado el argumento de la hipotética fundación Real del Monasterio por Alfonso I en el siglo VIII, época de la que hasta ahora no se conservaba ningún vestigio material ${ }^{7}$.

5 Las obras y las excavaciones arqueológicas fueron promovidas por la Consejería de Cultura del Principado y el Ministerio de Economía y Comercio.

6 El Proyecto de Restauración tenía previsto la construcción de un semisótano para cocinas y almacenes sobre el que se situaría una terraza y un comedor. La aparición de los restos condicionó la modificación del proyecto inicial y los restos de la Huerta se conservaron y sellaron dejando el espacio como zona ajardinada mientras que los del interior se acondicionaron para su exposición, siendo actualmente visibles en dos de las dependencias del Parador.

7 La referencia material más antigua relacionada con el pueblo de Villanueva era una inscripción de época romana localizada en el pueblo de Villanueva — actualmente desaparecida-, la «Estela de Nigriniano», dada a conocer por Hübner (CIL, II 2711, Berlín 1869-1892). 
Estas construcciones sufren sucesivos derrumbes y reconstrucciones como consecuencia de las avenidas y crecidas periódicas del río de las que se han registrado al menos cinco episodios ${ }^{8}$. A estas fases de inundación se corresponden otras tantas de construcción y reconstrucción que se suceden hasta la Baja Edad Media.

En otras dependencias intramuros del edificio monástico se han identificado igualmente los niveles de ocupación más antiguos: el de fundación, altomedieval, y el plenomedieval, en relación con la fase de remodelación Románica de la Iglesia a finales del siglo XII-principios del siglo XIII. Parte de estas estructuras se derrumban en la Baja Edad Media (siglo XV) y, definitivamente, en el siglo XVII (1694) cuando, según referencias documentales, se derriban las construcciones preexistentes para levantar los paños del claustro actual.

A este periodo (siglos XVII-XVIII) se corresponden las grandes reformas barrocas que han dado lugar a la configuración actual del monumento (fig. 6).

\section{Bibliografía}

Martínez, A. y Requejo, O., 1990.

Martínez, A. y Requejo, O., 1995: 298.

Requejo Pagés, O. et alii, 1998.

Requejo Pagés, O., 1999: 99-110.

Requejo Pages, O., 2000.

Requejo Pagés, O. y Jiménez-Sánchez, M., 2004: 287-292.

\subsection{Torre de Peñe Manil (Cebia, Cangas de Onis)}

Elevado pico (504 m) al sur del río Zardón que domina los valles de acceso a la comarca y conserva en la cima restos, muy deteriorados, de una antigua fortaleza.

El yacimiento se conoce desde que en el año 1906 Hermilio Alcalde del Río, prehistoriador de la cornisa cantábrica, realizó las primeras excavaciones. En una carta enviada al erudito y coleccionista de la zona, Sebastián Soto Cortés, quedan reflejadas las conclusiones de su trabajo y los dibujos de los objetos encontrados (Diego Somoano, C., 1960: 288-290). Posteriormente fue estudiada por J.M. González y Fernández-Vallés junto con otras fortalezas medievales de la región (González, J. M., 1976: 336-339). Entre los hallazgos realizados por Alcalde del Río figuraban varios fragmentos de cerámica entre los que destacan dos fragmentos de copas y una copa de forma semiesférica sin decoración, «una olla de cerámica mal cocida decorada con franjas de líneas incisas e inclinadas formando entre sí ángulos». Los restantes fragmentos son de «cerámica incisa con pasta tosca, grue-

${ }^{8}$ Sobre el particular ver Requejo Pagés, O. y Jiménez-Sánchez, M., 2004: 287-292. 


\section{O. REQUEJO PAGÉS}
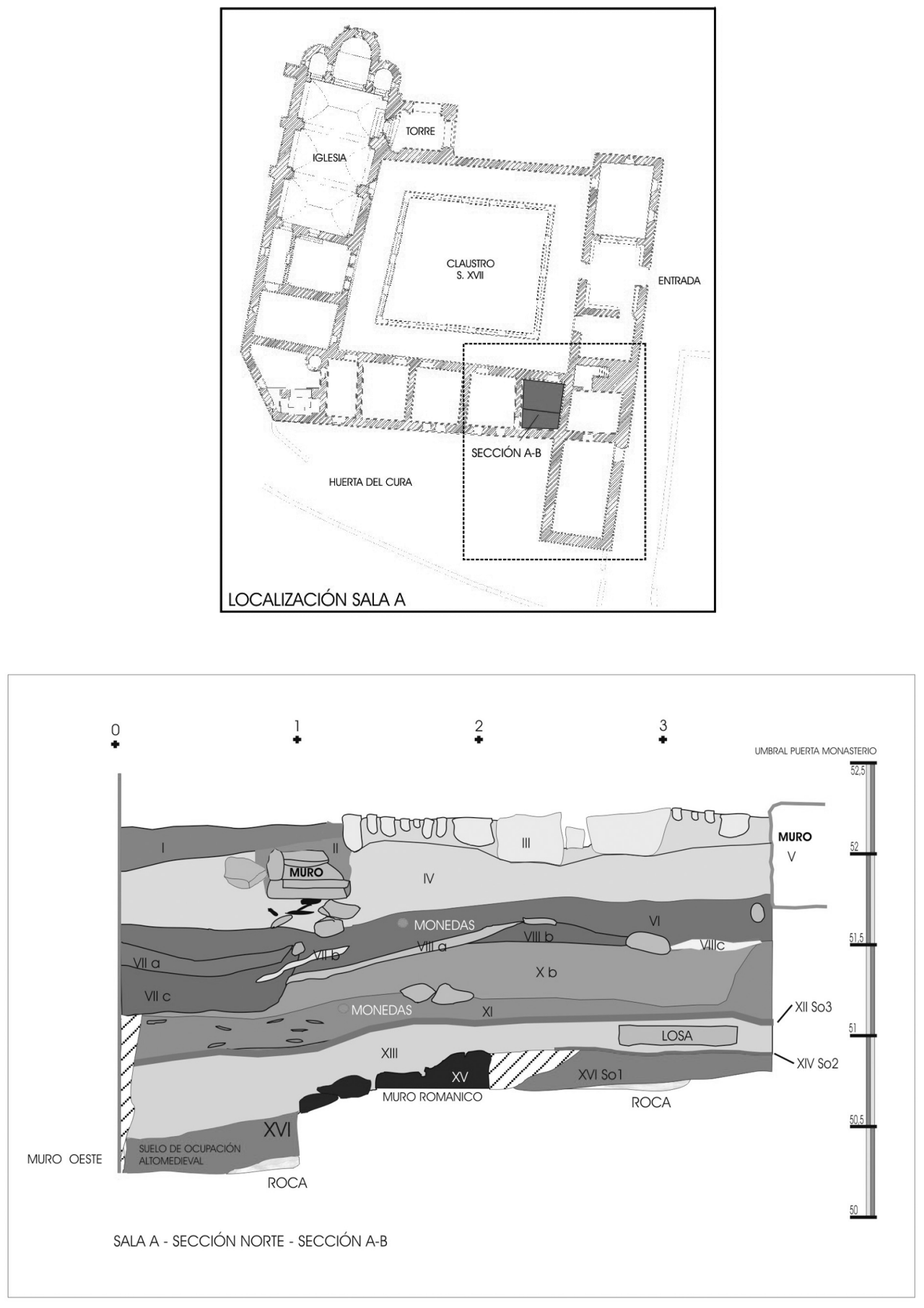

Fig. 6. Sección estratigráfica del monasterio de Villanueva. 
sa y mal cocida. Están decorados con líneas en el sentido circular de la vasija y perpendicular y oblicuos a ésta». Estos materiales se localizaron en los fondos del Museo Arqueológico Provincial y a ellos hay que añadir el lote recogido durante los trabajos de prospección de la zona en el año 1984, dados a conocer y publicados en el año 1986.

Bibliografía

Diego Somoano, C., 1960: 288-290.

González, J. M., 1976: 336-339.

Martínez, A. y Requejo, O., 1986: 333-345.

\subsection{Torre de la Porra Portiella (Següenco, Cangas de Onís)}

Se localiza, como la anterior, en un elevado pico (562 m) de difícil acceso y alto valor estratégico, flanqueado al oeste por el arroyo de Fuente Mujosa, tributario del río Covadonga. Los vestigios de la fortaleza son apenas visibles y únicamente se conservan restos en el extremo Este.

A fines del siglo XIX se realizan excavaciones de las que se da cuenta en el tomo II de la obra Asturias, de Bellmunt y Canella. Se recogieron restos de cerámica de diversas épocas, una flecha doblada por su punta, instrumentos de hierro de uso desconocido y abundante malacofauna. Se desconoce su paradero aunque en la «Colección Soto Cortés» había algunas lanzas procedentes de este yacimiento.

Los materiales que se presentan proceden de la prospección de la zona realizada en el año 1984.

Bibliografía

Bellmunt, O. y Canella, F., 1987: 13.

Diego Somoano, C., 1960: 288-290.

Martínez, A. y Requejo, O., 1986: 333-345.

\subsection{Necrópolis de la Ermita de Santa Cruz (Vega de Contranquil, Cangas de Onís)}

La Ermita de Santa Cruz fue edificada bajo el reinado de Favila y consagrada por el obispo Asterio en el año 737, según rezaba en la inscripción desaparecida en el año 1936 junto con la capilla que había sido reedificada en $1632^{\circ}$ (Diego Santos, F., 1994: 226-227).

9 Sobre la documentación y noticias de la ermita de Santa Cruz véase García de Castro, C., 1995: $511-512$. 
Las primeras noticias de excavaciones arqueológicas en la ermita se remontan a mediados del siglo XIX y fueron realizadas por Antonio Cortés Llanos (Canella y Secades, F., 1871: 27-28; Canella y Secades, F., 1872: 10). Posteriormente la necrópolis fue parcialmente excavada por el conde de la Vega del Sella en 1891 al realizar una exploración del dolmen que se halla bajo la capilla. Sus trabajos se centraron en el sector Este del yacimiento y se concretaron en una serie de zanjas a partir de la base del túmulo ${ }^{10}$. Las excavaciones realizadas en el año 1988 estuvieron condicionadas por el descubrimiento de un sector de la necrópolis durante las obras de construcción de un chalet en las inmediaciones de la ermita de Santa Cruz, en la finca de Don Constante, donde se documentaron un total de 11 enterramientos (Martínez Villa, A., 1992: 155-160). Las tumbas estaban construidas con lajas de caliza y cuarcita de pequeño tamaño y cantos rodados, trabados con arcilla amasada. La planta era de forma aproximadamente rectangular y el esqueleto se orientaba al Oeste en posición decúbito supino; bajo la cabeza, en ocasiones y a modo de almohadilla, un bloque de arcilla o canto rodado. Las inhumaciones carecían de ajuar y únicamente se registró el hallazgo de una teja decorada con un motivo en forma de espiral, que probablemente procedería de la cubierta de la capilla del siglo VIII, y fragmentos cerámicos procedentes de la removilización de los estratos al practicar las fosas de inhumación ${ }^{11}$. Los enterramientos estaban sellados por un nivel arcilloso y una capa con materiales constructivos procedentes de la reedificación de 1632 (fig. 7).

Se han diferenciado dos fases de enterramientos: la más temprana y más próxima a la capilla (siglos VIII-X) estaría representada por tumbas construidas con lajas de cuarcita o calizas cretácicas y cantos rodados, con cobertera de lajas y cantos unidos con arcilla (selladas por el nivel Illb). La segunda fase (siglos XI-XIII) estaría representada por las tumbas localizadas en el extremo norte de la necrópolis (excavadas en el nivel $\mathrm{llb}$ ) las cuales presentan diferencias morfológicas respecto a las de la fase anterior: además de las inhumaciones de fosa simple y lajas hay que destacar las de forma trapezoidal con orejeras en la cabecera.

La necrópolis de tumbas de lajas de Santa Cruz comenzaría a desarrollarse a partir del siglo VIII, fecha temprana para las necrópolis de tumbas de lajas, defendida también en contextos palentinos y cántabros ${ }^{12}$.

10 Vega del Sella, Conde de la, 1919.

11 Se debe señalar la presencia intencionada de carbones vegetales en el interior de algunas tumbas y de pequeñas cuentas de azabache sobre la cubierta de otras ( $A, B$ y $D)$ o en el interior (F), circunstancia interesante si se tiene en cuenta el carácter mágico y protector que se atribuye a este material. En otra de las tumbas $(\mathrm{C})$ se documentó un fragmento de concha, práctica documentada igualmente en San Salvador de Valdedios (Requejo, O., Martínez, A. y Jiménez, M., 1992: 179-188) y San Vicente de Serapio (Requejo, O., 1995: 1293-1296). Estas evidencias son sumamente interesantes porque suponen una pervivencia de elementos religiosos pre-cristianos entre estas comunidades.

12 Lo confirman las excavaciones de El Castellar (García Guinea, M. A., González Echegaray, J. y Madariaga de la Campa, B., 1963: 30-31; Monte Cildá (García Guinea, M. A., González Echegaray, J. y Sanmiguel Ruiz, J. A., 1966: 30-32), ambas en el Norte de Palencia, y de Cantabria (García Guinea, M. A., 1979: 111-121; Bohígas, R., 1986: 12). En Asturias tenemos como referencias más próximas y tempranas la necrópolis de San LLorente en Rodiles, Villaviciosa, con piezas de filiación visigoda y tumbas mixtas de tégulas y lajas (González y Fernández-Vallés, J. M. 1976: 228-230. 


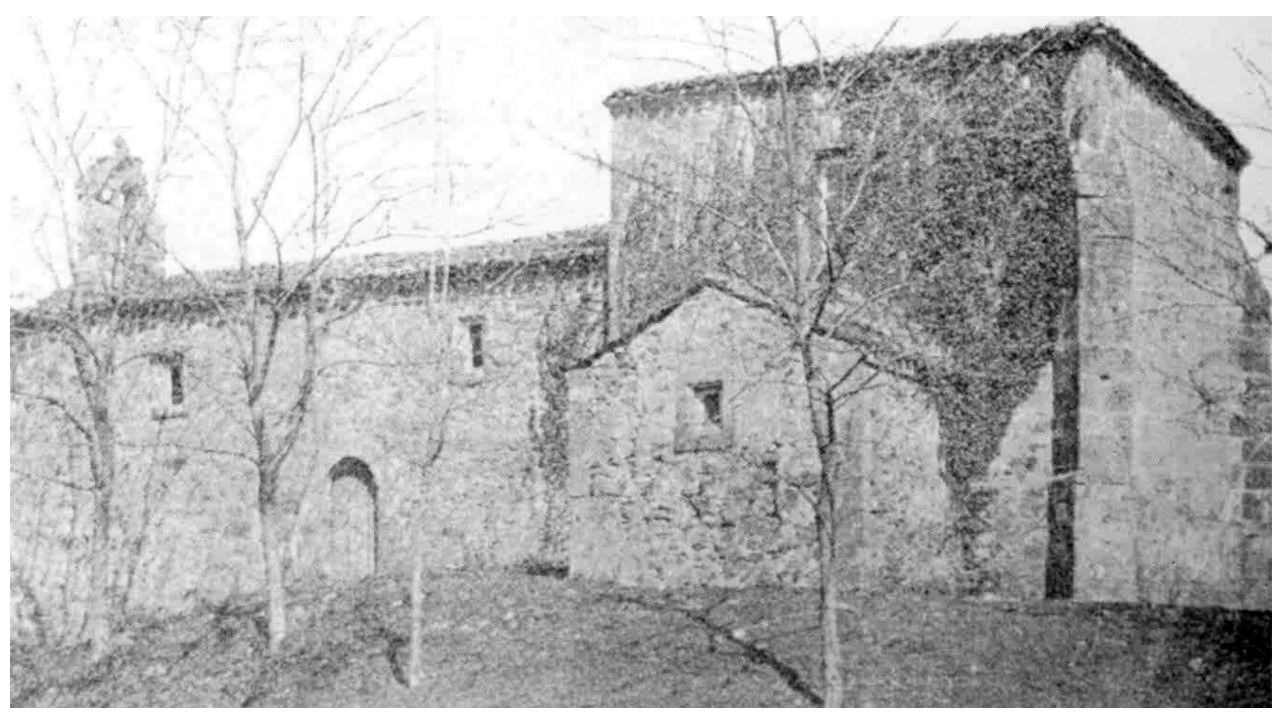

Fig. 7. La ermita de Santa Cruz antes de la guerra civil.

La vida de la necrópolis se prolongaría por lo menos hasta el siglo XII, momento en que Santa Cruz pasa a depender del monasterio de San Pedro de Villanueva. A finales de esta centuria se construye la iglesia de San Pelayo o Cangas de Arriba que sustituirá, a finales del siglo XIII o principios del XIV, a la de Santa Cruz como lugar de culto y de enterramiento.

\section{Estratigrafía}

la-Capa edáfica superficial. Gran cantidad de fragmentos de loza y de cerámica popular asturiana.

Ib-Capa de color pardo-grisáceo documentada en el sector SO del yacimiento. Se identifica con la capa de materiales constructivos procedentes de la reedificación del siglo XVII. Abundantes restos de loza y cerámica común, así como fragmentos de tejas y cantos rodados.

Ila-Zonas alteradas por los enterramientos de la Fase 2 (s. XI-XIII) que rompen el nivel Ilb.

llb-Capa de tonalidad pardo-rojiza que se extiende por todo el yacimiento, apreciándose con mayor claridad y potencia hacia el SO. Se trata de un antiguo suelo, sellado por la capa antes descrita (Ib), que cubre las inhumaciones de la Primera Fase y está roto por las de la Segunda.

Ilc-Se trata de lentejones situados entre la base del nivel II y la parte superior del III. Este nivel es el que proporcionó los materiales más antiguos y se corresponde con las inhumaciones de la Fase 1 (s. VIII-X). 
III-Aparece en toda la zona excavada y está constituido por limos arcilloso-arenosos de tonalidad crema y con $20 \mathrm{~cm}$ de espesor. En este nivel aparecieron materiales líticos (lascas, láminas, núcleos de sílex y de cuarcita, raspadores etc.), relacionables con el dolmen situado bajo la capilla.

IV-Limos y arcillas de origen fluvial.

\section{Bibliografía}

Vega del Sella, Conde de la, 1919.

Martínez Villa, A., 1992: 155-159.

\section{CRITERIOS DESCRIPTIVOS Y CONSIDERACIONES TÉCNICAS}

Antes de presentar los materiales de los diferentes yacimientos consideramos imprescindible hacer referencia a los criterios y conceptos utilizados para describir y caracterizar las cerámicas. A la hora de analizar las producciones cerámicas y describir sus propiedades físicas (textura, dureza, color) hay que tener en cuenta las variables que las han condicionado como son la composición de las arcillas y los procesos técnicos implicados: la factura y, fundamentalmente, el proceso de cocción ${ }^{13}$. Para entender e interpretar correctamente las variables y factores que han determinado las propiedades físicas de las cerámicas es necesario distinguir el papel y la incidencia de cada factor. El rigor en las descripciones y los conceptos que se manejan tiene gran trascendencia - lamentablemente obviada en ocasiones-, puesto que las características físicas descritas nos están hablando de procesos técnicos concretos.

\subsection{Propiedades físicas de las cerámicas}

En una primera fase, los criterios de clasificación de los materiales cerámicos en diferentes grupos o producciones se basan en sus propiedades físicas (macroscópicas): la calidad y características de la pasta y el color. En una fase posterior, los análisis arqueométricos permitirán definiciones más precisas aunque su aplicación sistemática está condicionada por la disponibilidad de medios técnicos y de financiación.

${ }^{13}$ El grado de precisión de las descripciones está condicionado y determinado por los criterios, conceptos y conocimientos que manejen los arqueólogos. Las descripciones incorrectas de dichas propiedades dan lugar a interpretaciones erróneas de los procesos técnicos que las originan y, por consiguiente, a errores en las conclusiones inferidas. Es preciso, por tanto, conocer bien los procesos implicados en la producción cerámica para interpretar correctamente las propiedades físicas de las piezas que se describen y también los criterios y conceptos utilizados. 


\subsubsection{Textura}

La textura es una cualidad que se define con el tacto, no con la vista. Las definiciones basadas en impresiones visuales no coinciden a veces con las del tacto. La textura está determinada sobre todo por las «impurezas», desgrasantes, cantidad, tamaño de grano, forma, porosidad de la arcilla y también por el acabado y el tratamiento superficial. En base a este criterio, las cerámicas se califican de finas, groseras o calidades intermedias. Una pasta fina (suave al tacto, lisa y uniforme) no pone límites al método de acabado al contrario que una de textura grosera ya que pocas pueden ser alisadas cuando el encogimiento por secado saca a la luz los granos groseros. La pasta grosera (superficie áspera, rugosa y a apariencia tosca) generalmente se denomina «común» y también utilitaria o culinaria.

\subsubsection{Dureza}

Esta propiedad está determinada por la composición de la pasta y las condiciones de cocción. Debido a la diferente composición de las arcillas, éstas endurecen a distinta temperatura. Es un error creer que la dureza es siempre un indicador de la temperatura de cocción y es preciso valorar dos premisas que hay que tener en cuenta a la hora de interpretar esta propiedad:

- La dureza no siempre es sinónimo de cocción a elevadas temperaturas ${ }^{14}$.

- También hay que tener en cuenta que la identidad de dureza en dos cerámicas no implica idénticas condiciones de cocción si la composición de las pastas es diferente ${ }^{15}$.

La cerámica «dura» indica, de una manera general, que ha sido cocida a una temperatura relativamente alta (para esa arcilla en concreto) o en una atmósfera que promueve la vitrificación (reductora).

\subsubsection{Color}

El color es una de las propiedades físicas determinantes a la hora de describir los productos cerámicos. A falta de otros análisis, determina que los materiales se clasifiquen como cocidos en atmósfera reductora u oxidante e, indirectamente, el tipo de hornos y procesos de cocción.

El color de las cerámicas es resultado de los efectos de la cocción, efectos que dependen de la atmósfera, duración y temperatura de cocción y que está condicionado igualmente por la composición de las arcillas. Las arcillas están co-

${ }^{14}$ Se han realizado experimentos y se ha podido comprobar que dos fragmentos cerámicos con una gran diferencia de dureza, el más blando había sido cocido a una temperatura $500^{\circ}$ por encima del más duro. Sólo cuando la composición de las pastas es idéntica, la diferente dureza implica diferentes temperaturas de cocción (Sheppard, A. O., 1954: 114).

15 Las pastas de alta temperatura necesitan un tiempo de cocción corto para alcanzar la dureza y las de baja temperatura, un tiempo de cocción prolongado. 
loreadas principalmente por las impurezas que contiene, sobre todo, materia orgánica ${ }^{16}$ y componentes de hierro. La cantidad, el tamaño y la distribución de las partículas de hierro determinarán, en cierta medida, si una arcilla será blanca, acastañada o roja en condiciones de completa oxidación ${ }^{17}$. Además de los óxidos de hierro, otros componentes de la arcilla (carbonatos, óxidos) son responsables del color.

Conocer estos factores y variables resulta esencial a la hora de abordar el estudio de los materiales cerámicos pero en la práctica, sin embargo, interpretar el color de las piezas y determinar el modo de cocción resulta mucho más complejo, máxime cuando se desconoce la composición de las arcillas y los tipos de hornos utilizados.

\subsection{Procesos técnicos}

Determinadas dudas y dificultades observadas a la hora de estudiar los materiales cerámicos plantearon la conveniencia de profundizar en el conocimiento de los procesos técnicos implicados: la factura y la cocción.

\subsubsection{Factura}

La factura, operación por la que se da forma a una pasta cerámica, es el modo en que se fabrican las vasijas cerámicas. Con el torno la forma cerámica se consigue por la fuerza centrífuga desarrollada por un movimiento circular. Son varios los calificativos que acompañan al término torno y que aluden, bien a sus características tipológicas (torno bajo: una rueda-torno alto: dos ruedas), a la velocidad de rotación (torno lento- torno rápido) o al modo de imprimir fuerza a la rueda (torno de mano-torno de pie) $)^{18}$.

La diferenciación de facturas a torno bajo o torno alto resulta en ocasiones problemática puesto que la regularidad de las paredes y de las líneas de torneado no

${ }^{16}$ La materia carbonosa solo colorea la cerámica si hay ausencia o insuficiente oxidación; cuando la oxigenación es la adecuada, se descompone y se libera en forma de dióxido de carbono.

17 El color se toma a veces como base para juzgar el porcentaje de óxido férrico en la arcilla pero la mayoría de las veces es una aproximación - a veces engañosa y errónea- porque la distribución y el tamaño de las partículas de óxido férrico y de la propia arcilla tienen también una considerable influencia en el color de las pastas.

18 El torno bajo, lento, o de mano, también denominado torneta, es una rueda de barro cocido, madera o piedra que gira alrededor de un eje y a la que se imprime velocidad con la mano. En Asturias se empleaba por lo menos hasta mediados del siglo XIX; consistía en una rueda o plataforma de madera de $80 \mathrm{~cm}$ de diámetro y grosor de unos $7 \mathrm{~cm}$. En la parte inferior llevaba un travesaño para impedir que la rueda se torciera al girar y un eje de madera que unía la rueda con una pieza fija de madera o piedra (Feito, J. M., 1985: 33). Con la torneta se combina el modelado a mano («urdido») y la fuerza centrífuga del torno. Esta alternancia de torneta-urdido es lo que algunos autores denominan «torneado intermitente» (Matesanz Vera, P., 1987: 254). El torno alto, rápido o de pie consta de dos ruedas unidas por un eje y la inferior es impulsada por la fuerza del pie por lo que el alfarero aplica a la rueda un impulso constante y regular, quedando las manos libres para modelar las vasijas. 
es exclusiva del torno alto ya que con la torneta se obtienen superficies igualmente regulares ${ }^{19}$.

Optamos por el empleo del término torneta cuando las paredes no son regulares y se observa la impronta de los dedos en las paredes internas de las vasijas. El término torno (alto o de pie) lo reservamos a las piezas en las que las líneas de torneado sean evidentes, finas y regulares, al igual que las paredes ${ }^{20}$.

\subsubsection{Cocción}

La cocción de los productos cerámicos es determinante en el estado final de los productos cerámicos y está condicionada por los sistemas de transmisión del calor utilizados, los hornos, y por las distintas fases y factores que intervienen en el proceso de cocción.

\section{TIPOS DE HORNOS}

La transmisión del calor - forma en que se aplica y cesa el calor-, puede realizarse por varios procedimientos ${ }^{21}$ y a cada sistema o procedimiento de cocción se asocia a un tipo de horno ${ }^{22}$.

En Asturias los hornos tradicionalmente utilizados por la alfarería tradicional eran de tres tipos:

\section{1. «descubierto de doble cámara»}

En la parte inferior está la caldera o fogón y en la superior el horno propiamente dicho donde se colocan las piezas. Los dos espacios están comunicados

19 Tuvimos ocasión de comprobarlo personalmente en el alfar de Faro (Oviedo): piezas realizadas con el torno bajo o de mano presentan paredes regulares, con líneas de torneado visibles y uniformes que podrían interpretarse como realizadas a torno alto o de pie. Somos conscientes de las limitaciones y dificultades de interpretación de este aspecto técnico y siempre hay que considerar un margen de error en la interpretación cuando la factura no es evidente, máxime cuando la práctica totalidad de las piezas presentan un estado fragmentario y el tamaño de los fragmentos es muy reducido.

${ }_{20}$ En los alfares tradicionales de la zona de Cangas de Onís se utilizaba la rueda baja como se puede apreciar en la ilustración de Manuel Rodríguez, alfarero de Soto de Dego, reproducida por J. M. Feito $(1985: 199)$

21 Procedimientos de transmisión del calor:

- Contacto: Es el procedimiento más rudimentario: las piezas cerámicas se rodean de combustible leñoso y se prende fuego. La atmósfera será reductora (las cerámicas se someten directamente a la acción de las llamas y el humo, que ejercen un papel oscurecedor) y la cocción imperfecta.

- Convección: Las piezas se colocan en un tubo o chimenea y se conducen las llamas producidas por un hogar; las llamas producen corrientes de convección al pasar por un tubo o chimenea. La convección tiene ventajas para conseguir fácilmente temperaturas altas pero los residuos de la combustión contaminan las piezas.

- Radiación: Las piezas no están en contacto directo con el fuego. Se cuecen en hornos cerrados en los que las cerámicas están en la cámara de cocción sin estar en contacto directo con las llamas (Pastor Moreno, A., 1992: 24).

22 Sobre tipología de hornos en España y Portugal ver la clasificación realizada por Sempere en función de la técnica de cocción y de los elementos arquitectónicos que definen el horno (Sempere Ferrandiz, E., 1992: 198). 
por los agujeros practicados en la criba que separa ambos compartimentos. Después de cocer se tapa cuidadosamente 23 .

2. «descubierto de doble cámara pero recubierto con tapines, monte bajo o cenizas»

Las piezas se cubren con tapines que se van reponiendo a medida que se queman; cuando el horno alcanza altas temperaturas y el fuego sale por el único agujero que queda en lo más alto del horno se tapa herméticamente con tierra al igual que la boca del horno y se deja así durante varios días ${ }^{24}$.

Estos hornos suponen una gran evolución ya que al incorporar al horno unas paredes que protegen la cerámica y la aíslan del fuego, se elevan las temperaturas y se produce una mejora en el control de la corriente de aire y en la combustión.

\section{3. «horno cubierto llamado árabe»}

Posee dos huecos de acceso: el fogón en la parte inferior (puede tener de 1 a 4 huecos) y el superior o puerta de entrada para cargar las piezas. Existen muchas morfologías pero lo que tienen en común es la bóveda, generalmente «a la romana», con filas de ladrillos puestos de canto. Con los hornos cerrados se consigue elevar la temperatura de cocción por encima de los $1000^{\circ}$ y mantenerla uniforme y durante más tiempo ${ }^{25}$.

Además de estos hornos, se emplearían con seguridad sistemas de cocción más primarios como el «horno-hornera» que consiste en una oquedad u hoyo de 20 a $50 \mathrm{~cm}$ de profundidad excavada en la tierra o circundada de piedras de diámetro entre los 3 y 5 metros. Sobre el hoyo se pone en ocasiones un lecho de hierba o paja para aislar la humedad de la tierra; se colocan las piezas y se tapan con

${ }^{23}$ El antiguo horno de Faro (Limanes, Oviedo) era de estas características, al igual que los de los alfares tradicionales de la zona de Cangas de Onís (Feito, J. M., 1985: 34). Podemos hacernos una idea precisa del antiguo horno del alfar de Faro gracias a la descripción que en el año 1891 publican S. Cabal y G. Villamil con motivo de una excursión universitaria realizada a Faro: «Son estos (los hornos) formados por una pared circular de mampostería, en forma de tubo algo embudado, de una cavidad aproximadamente de dos metros y medio de diámetro y descubiertos por la parte superior. Se construyen en terreno sumamente inclinado, a fin de que por un lado quede la altura del horno al igual del monte y por el otro presenta la pared una elevación total de unos cinco metros. A dos escasos del suelo, y sirviendo de base a las vasijas que se someten a la acción del fuego tiene un fondo cubierto de agujeros en forma parecida a la piel de criba, debajo de la que ha de colocarse el rozo (tojo corto) o material combustible, introducido en el horno por una pequeña boca cuadrilátera. Sobre la tapa taladrada, dejando descubiertos los agujeros para que por ellos salga el calor de las llamas, colócanse las piezas (...) Una vez preparado todo, préndese fuego al combustible que deberá arder veinte y cuatro horas, después de las que, y aprovechándose de estar tan alto el terreno (...) acuden a taparle cuidadosamente para procurar se conserve la alta temperatura el mayor tiempo posible» (Cabal, S. y Villamil, G., 1891).

${ }_{24}$ Este es el tipo de horno utilizado en Llamas de Mouro, Cangas de Narcea, (Comunicación personal del propietario del alfar).

25 Los hornos de Faro de este tipo están construidos con ladrillos macizos, revestidos de piedra por fuera y de barro en el interior. Antes de utilizarlo se cocía el horno como si fuera una pieza más (Feito, J. M., 1985: 133). 
ramajes que se reponen a medida que se van consumiendo. Cuando las piezas están cocidas se cubren con leña y tapines que cuando empiezan a arder se cubren con tierra para concentrar el monóxido de carbono y elevar la temperatura al máximo. Se cuece por la técnica de contacto directo ya que leña y cerámica están juntas formando una hoguera y la atmósfera de cocción será reductora. Como ventajas, señalar que son económicas ya que precisan poco consumo de leña y se cuece con gran rapidez puesto que la hornada solo tarda en cocer 3 a 4 horas, pero la contrapartida es que quedan poco cocidas ya que la temperatura de cocción difícilmente supera los $800^{\circ}$ y algunas piezas presentan manchas por haber estado en contacto directo con la llama. La cocción en hornera se asocia a modelado «urdido» y torneta (Sempere Ferrándiz, E., 1992: 200).

Aparte de los hornos tradicionales, la arqueología regional ha suministrado algunos testimonios sobre antiguos hornos. Se conoce la existencia de un alfar que funcionó junto a la Catedral de Oviedo, en el solar que hoy ocupa el Palacio Arzobispal: se trataba de un horno excavado en la roca cuya hornilla estaba construida con grandes ladrillos de material refractario ${ }^{26}$.

En algunas publicaciones se alude a la existencia de alfares medievales de Quiloño, Castrillón, al pie del castro de La Armada pero se trata de hornos de época Moderna ${ }^{27}$. En los últimos años se han producido nuevos descubrimientos como el conjunto de hornos documentados en Cayés, Llanera, de cronología romana $^{28}$.

\section{FASES Y CONDICIONES DEL PROCESO DE COCCIÓN}

1. Se diferencian dos fases en el ciclo de cocción: la cocción en sentido estricto y la postcocción.

26 Los autores del hallazgo no precisan su cronología pero realizan una detallada descripción: «El horno (...) está excavado en la misma roca, que presentaba las huellas de calcinación propias de la permanente combustión y de las altas temperaturas sufridas por la piedra; la hornilla, de material refractario, al fondo del horno cuyo largo total no era inferior a los cuatro metros (...); los residuos del barro encontrados en el piso que generalizaba la parte exterior de lo que debió ser la boca del horno, un espacio de unos dos metros y medio por uno y medio, conseguido sobre la roca misma desbastada al efecto de dejarla como una verdadera platina, seguramente taller de alfarería. En fin, la altura de las paredes del horno que, hasta ganar el nivel del suelo regularizador del que fue Palacio Episcopal luego, no era inferior a dos metros, y el hecho de que este horno no pudo pertenecer al servicio de los edificios cuyos eran los umbrales encontrados (...), porque se halló dentro del espacio que ocuparía en aquellos palacios una estancia de servicio...» (Fernández Buelta, J. M., 1948: 90; 1985 reed.: 64).

27 En Feito, J. M., 1985: 256. Fueron reconocidos por D. Juan Uría y D. Emilio Olávarri quienes concluyeron que correspondían al siglo XVIII (Comunicación personal de D. Emilio Olávarri).

28 La localización de los hornos se produjo durante los trabajos de Control y Seguimiento Arqueológico de las obras de construcción de las Carreteras AS-17 y AS-18: Oviedo-Lugones- Llanera-Gijón y las excavaciones arqueológicas fueron promovidas por la Consejería de Fomento del Principado de Asturias (Requejo Pagés, O. 1999). No es descartable que los establecimientos agropecuarios tipo «villa» contaran con alfares para la producción de manufacturas de uso cotidiano como pone de manifiesto la relativa abundancia de piezas defectuosas identificadas entre los materiales de las villae de Murias de Beloño y Murias de Paraxuga. 
La cocción es un proceso de oxidación y el material cerámico es el resultado de la combinación química de óxidos que han reaccionado por efecto de la temperatura (Pastor Moreno, A. 1992: 21). Durante esta fase los productos cerámicos adquieren sus características principales (color, textura, dureza); el aumento de la temperatura es lento y progresivo y debe mantenerse constante el tiempo necesario, al que la alimentación del horno.

En la fase siguiente, la postcocción (desde que se empieza a enfriar la carga hasta el deshornado), se deja de alimentar el horno, se produce el enfriamiento de la carga y las cerámicas adquieren sus propiedades definitivas (Matesanz Vera, P., 1987: 256). Cuando se deja de alimentar el horno se produce una oxidación inmediata (postcocción oxidante) y si al dejar de alimentar el horno se cierran todos los orificios de éste, se produce una postcocción reductora (Thiriot, J., 1986: 61).

De modo genérico se distinguen cuatro modos de cocción que determinan, entre otros factores, el color de los productos cerámicos (Picon, M., 1973):

- Modo A: Reductora-Oxidante (cerámicas con núcleo gris-exterior rojo).

- Modo B: Reductora-Reductora (cerámica gris).

- Modo C: Oxidante-Oxidante (cerámica roja).

- Modo D: Oxidante-Reductora (cerámicas con núcleo rojo-paredes grises).

Este es el criterio descriptivo genérico que hemos utilizado en la interpretación del color de los materiales estudiados.

2. Durante la combustión se pueden producir, en términos generales, varias condiciones o atmósferas de cocción: oxidante, incompletamente oxidante y reductora.

La atmósfera oxidante contiene oxígeno libre que favorece la oxidación de la pasta, sobre todo de la materia orgánica y los componentes ferrosos de la arcilla. El grado de oxidación depende de la proporción de oxígeno, la temperatura y duración de la cocción y las propiedades de la materia arcillosa. Cuando existe una buena corriente de aire, superior a la que se precisa para quemar el combustible, y los constituyentes de la pasta han tomado más oxígeno del que precisan, los óxidos alcanzan el más elevado grado de oxidación ${ }^{29}$ y se vuelven rojos (Sheppard, A. O., 1954: 213-214 y 370-371).

La oxidación se obtiene ya a los $750^{\circ 30}$ siempre que la llama sea completamente oxidante, se deje abundante entrada de aire y las piezas tengan espacios entre sí31.

${ }^{29}$ Los óxidos de hierro se transforman en férricos y tiñen las pastas.

30 Para obtener llama oxidante algunos alfareros empleaban como combustible estiércol y excrementos, de elevado poder calórico, obteniendo temperaturas de hasta $850^{\circ}$ en prolongada cocción a fuego abierto (Fernández Chiti, J. 1980: 9).

${ }_{31}$ En el curso de una cocción oxidante se puede producir una reducción en aquellos lugares donde el oxígeno no puede acceder en cantidades suficientes lo que puede deberse al modo de apilar las piezas. 
La oxidación de las pastas no depende de una única circunstancia sino de la combinación de una serie de factores:

a) Se precisa una atmósfera de cocción con libre circulación del aire.

b) La temperatura de cocción ha de ser lo suficientemente alta, por lo menos $700^{\circ}-750^{\circ}$.

c) La duración de la cocción ha de ser lo suficientemente prolongada para que se produzca la completa oxidación de la pasta.

d) Hay que tener en cuenta la composición de las pastas puesto que un mismo fuego puede oxidar completamente una arcilla y parcialmente otra, en función de los constituyentes de las arcillas.

Las cerámicas oxidadas, por tanto, han sido cocidas en atmósfera oxidante, con libre circulación de oxígeno y pueden presentar una variadísima gama de tonalidades del amarillo al rojo.

La incompleta oxidación de las cerámicas se produce cuando la corriente de aire es insuficiente y/o el tiempo de cocción ha sido corto, aunque también depende de otros factores como la composición y propiedades de las arcillas. La superficie puede mostrar diferentes grados de oxidación (diferentes tonalidades) 0 manchas oscuras provocadas por el humo generado por el combustible. Cuando la corriente de aire es insuficiente, el combustible produce humo que contiene carbón coloidal y da lugar a la formación de hollín que mancha o tiñe las cerámicas y se produce una pérdida térmica en forma de dióxido de carbono y humo (Sheppard, A. O., 1954: 213).

Las arcillas incompletamente oxidadas dan colores marronáceos, pardos y amarillentos ${ }^{32}$.

La oxidación se produce progresivamente del exterior al interior de las paredes por lo que cuando el corazón es negro y las paredes beige o rojizas, se ha producido una incompleta oxidación ${ }^{33}$.

32 Los tonos marronáceos plantean problemas de interpretación: mientras que para Sheppard (1954) indican una incompleta oxidación, otros autores son más partidarios de incluirlos dentro de las atmósferas reductoras teniendo en cuenta que para conseguir esta atmósfera no se precisan hornos y resulta por tanto más económico (Matesanz Vera, P., 1987: 255). También hay que tener en cuenta otras variables a la hora de interpretar este color y es la presencia de compuestos de manganeso que provocan tonalidades marronáceas y marrones oscuras en cocción oxidante y reductora (Krauser\&Plaul\&Zöllner, 1973: 33).

El color marrón se puede explicar por diferentes circunstancias y condiciones:

a - Arcillas incompletamente oxidadas: la materia orgánica presente en la pasta se ha oxidado pero los componentes de hierro no están totalmente oxidados.

b - Hay que tener en cuenta los componentes de la pasta: si tiene componentes de manganeso da tonos marrones en atmósfera reductora y oxidante. Si tiene un pequeño porcentaje de óxido de hierro da tonos marrones en cocción reductora.

c - Otros autores consideran de manera genérica que se trata de piezas cocidas en atmósfera reductora que es más fácil y económica de obtener.

${ }^{33}$ La incompleta oxidación está en relación, por tanto, con la duración del tiempo de cocción ya que la cerámica que ha estado solo un corto periodo de tiempo en contacto con los gases que se forman durante 
La atmósfera reductora, al contrario que la oxidante, no contiene oxígeno libre por lo que los componentes ferrosos de la pasta no se oxidan y la combustión de la materia orgánica se produce lentamente. La reducción se consigue cerrando los pasos de aire y dejando quemar el combustible con un mínimo de aire por lo que éste toma el oxígeno necesario para su combustión de los componentes de la pasta cerámica (Shaw, K., 1974). Al perder oxígeno, las cerámicas se vuelven grises o negras y si, además, la pasta contiene materia carbonosa ésta no se libera, como ocurre en la cocción oxidante, sino que se «reduce» y también tiñe la pasta de gris $^{34}$.

Esta atmósfera influye en los componentes de las arcillas ya que favorece la intensificación del efecto de los fundentes por lo que las pastas se vitrifican a más baja temperatura y el aporte insuficiente de aire conlleva la transformación del óxido férrico en óxido ferroso que no tiñe las pastas. Para que exista reducción tiene que haber un «agente reductor» (el principal agente reductor es el monóxido de carbono y también el carbón de leña) que, por reacción, al no haber oxígeno libre, lo toma de los constituyentes de la pasta (Krauser\&Plaul\&Zöllner, 1973: 33). En la práctica, se acostumbra a hacer reducción una vez alcanzada la temperatura máxima, cuando el material comienza a enfriar.

El enfriamiento, por tanto, es determinante en el color de las cerámicas. Cuando se realiza con el horno abierto y con corriente de aire (postcocción oxidante) se produce una reoxidación, por lo que si las piezas han sido cocidas en atmósfera reductora, las cerámicas presentarán tonalidades rojas en el exterior. Si el enfriamiento se hace con el horno cerrado, la postcocción será reductora, y si las piezas han sido cocidas en atmósfera oxidante, las paredes exteriores de las vasijas serán

la combustión presenta la superficie oxidada y el núcleo negro o gris (el interior de las paredes de la vasija a menudo contiene materia carbonosa no quemada debido a la insuficiencia de oxígeno), lo que para algunos autores es indicio de incompleta oxidación (Balfet, H., Fauvet. M.F. y Monzon, S., 1989: 67). Otros autores lo interpretan como cocción reductora con enfriamiento oxidante. Como se verá más adelante, no existe un criterio unánime sobre la explicación e interpretación del color del núcleo (ver Tabla 1).

${ }^{34}$ Respecto al color gris de las cerámicas, es necesario apuntar que, en sentido estricto, solo debe considerarse cerámica reducida aquella que ha sido cocida en atmósfera reductora y el óxido de hierro está presente en el más bajo grado de oxidación, presentando las pastas tonalidades que van del gris al negro. Es importante tener en cuenta que no todas las cerámicas grises han sido reducidas, han sido cocidas en atmósfera reductora. Las pastas también pueden estar coloreadas de color gris por carbón u hollín que las mancha durante la cocción: puede tratarse de cerámicas ahumadas cocidas en atmósfera oxidante: las piezas se cubren con ramas o estiércol que producen exceso de humo lo que impide la elevación de la temperatura y las pastas se tiñen de oscuro por el hollín y el humo. En este caso no es reducción propiamente dicha porque el oxígeno no ha sido tomado de los constituyentes de la arcilla. También el alfarero puede introducir en la pasta agentes reductores (estiércol seco en polvo mezclado con el barro) que teñirá las pastas de gris aunque la cocción sea oxidante a baja temperatura El color gris, por tanto, no es sinónimo de cerámica cocida en atmósfera reductora, aunque con frecuencia se utiliza la expresión "cocida en atmósfera reductora" como cajón de sastre para describir todas las cerámicas grises (Fernández Chiti, J., 1980: 9).

El color gris puede interpretarse teniendo en cuenta varias posibilidades:

a) Puede ser una pasta rica en materia orgánica e insuficientemente cocida.

b) Una pasta rica en óxido e hierro y cocción reductora.

c) Una pasta pobre en óxido de hierro y cocción no reductora (Alarçao, J. de, 1975: 26). 
El Registro Arqueológico en el territorio de Cangas de Onís (Principado de Asturias)...

Tabla 1. Interpretación del color del núcleo, nervio o corazón de las cerámicas

\begin{tabular}{|l|l|l|}
\hline \multicolumn{1}{|c|}{ Autor } & \multicolumn{1}{c|}{$\begin{array}{c}\text { Núcleo negro y paredes rojas } \\
\text { (RNR) }\end{array}$} & \multicolumn{1}{c|}{$\begin{array}{c}\text { Núcleo rojo y paredes negras } \\
\text { (NRN) }\end{array}$} \\
\hline Sheppard (1954) & c. incompletamente oxidante & c. oxidante - pc. reductora \\
\hline Krauser (1973) & c. reductora - pc. oxidante & c. incompletamente reductora \\
\hline Picon (1973) & c. reductora - pc. oxidante (Modo A) & c. oxidante - pc. reductora (Modo D) \\
\hline Alarçao (1975) & c. incompletamente oxidante & \\
\hline Matesanz (1987) & c. reductora - pc. oxidante & c. oxidante - pc. reductora \\
\hline Balfet et alii (1989) & c. incompletamente oxidante & \\
\hline Pastor (1992) & c. reductora - pc. oxidante & c. oxidante - pc. reductora \\
\hline
\end{tabular}

R: Rojo N: Negro C: Cocción PC: Postcocción.

grises $^{35}$. Además de la influencia de los procesos de cocción y postcocción, también se pueden producir modificaciones en el color por el uso que se da a las vasijas y por las transformaciones que sufre cuando han permanecido enterradas y su color original se ha modificado por las condiciones del suelo.

Aunque son diversas y no siempre unánimes las interpretaciones que sobre los colores de las pastas cerámicas han hecho diversos autores - tal como queda reflejado en la tabla adjunta -, nuestro criterio ha sido el de M. Picón, adoptado y utilizado por numerosos investigadores.

\section{YACIMIENTOS Y PRODUCCIONES CERÁMICAS}

Una vez explicitados los criterios técnicos y de interpretación utilizados en el estudio y clasificación de los materiales, éstos se han agrupado en diferentes producciones cerámicas aglutinadas en dos apartados: el primero, residual, correspondiente a las producciones de la antigüedad tardía (presente únicamente en Corao y Villanueva), y el segundo a las producciones de la Alta Edad Media.

\subsection{Yacimientos}

\subsubsection{Vega de Corao (Cangas de Onís)}

En el nivel más antiguo, correspondiente al suelo de ocupación de las estructuras (nivel IV), se registra un repertorio cerámico compuesto por un grupo mino-

35 La temperatura es un factor que influye decisivamente en el color puesto que en bajas temperaturas $\left(750^{\circ}-1080^{\circ}\right)$ se precisa mayor cantidad de óxidos que si se hornea a altas temperaturas $\left(+1100^{\circ}\right)$.

- Hasta los $1150^{\circ}$ el óxido ferroso se oxida y pasa a férrico, que tiñe intensamente las pastas de rosado, amarillento o rojizo, según el porcentaje.

- Por encima de los $1150^{\circ}$ el óxido férrico se descompone y las pastas se aclaran (también las aclara una cocción reductora a esa temperatura) (Fernández Chiti, J., 1980: 59 y 98). 
Tabla 2. Producciones cerámicas

\begin{tabular}{|r|l|}
\hline \multicolumn{2}{|c|}{ A. Producciones romano tardías (residuales) } \\
\hline A-1 & TSHT \\
\hline A-2 & Finas anaranjadas \\
\hline A-3 & Ollas borde plano inciso \\
\hline B. Producciones altomedievales \\
\hline B.1. Cerámicas con decoración incisa \\
\hline B-1-1 & Ondas incisas \\
\hline B-1-2 & Peine vertical \\
\hline B-1-3 & Líneas incisas entrecruzadas sin formar retícula \\
\hline \multicolumn{3}{|r|}{ B-1-4 } & Retícula \\
\hline B.2. Cerámicas con decoración pintada \\
\hline
\end{tabular}

ritario, residual, de cerámicas de tradición romano tardía ${ }^{36}$ (en la E1 se registró el hallazgo de un pequeño fragmento de TSHT y una pequeña muestra de cerámicas finas anaranjadas), y un lote mayoritario de materiales altomedievales. Se observa una clara evolución en la técnica y motivos decorativos de las cerámicas del nivel IV, en las que domina la incisión vertical a peine, y las del nivel III entre las que se impone la retícula incisa y la decoración pintada.

\begin{tabular}{|c|l|c|c|}
\hline \multicolumn{3}{|c|}{ FINCA DE SAN NICOLÁS, VEGA DE CORAO } \\
\hline \multicolumn{2}{|c|}{ Decoración } & Producciones altomedievales \\
\hline B-1 Incisa & Nivel IV & Nivel III \\
\hline b1-1 & Ondas incisas & $12,5 \%$ & $0 \%$ \\
\hline b1-2 & Peine vertical & $75 \%$ & $12,5 \%$ \\
\hline b1-3 & Líneas incisas entrecruzadas & $12,5 \%$ & $12,5 \%$ \\
\hline b1-4 & Retícula incisa & $0 \%$ & $25 \%$ \\
\hline B-2 & Pintada & $0 \%$ & $50 \%$ \\
\hline
\end{tabular}

\subsubsection{Monasterio de San Pedro de Villanueva (Cangas de Onís)}

En el caso del Monasterio de Villanueva, no se han registrado materiales de tradición romano tardía como en Corao. Únicamente se ha documentado una

${ }^{36}$ Es preciso hacer referencia al lote de cerámicas de la Edad del Hierro o, mejor, de Tradición del Hierro, localizadas al pie del yacimiento paleolítico de La Cavada, durante los trabajos de limpieza de uno de los cortes de la variante de Corao, a unos 150-200 al Oeste del yacimiento medieval (corte B: PK $6+020 / 40)$. Estas cerámicas hay que relacionarlas con las de los yacimientos castreños de Villaviciosa estudiados por J. Camino Mayor y datadas en la Edad del Hierro I y II, producciones cerámicas locales con una larga y añeja tradición y perduración en el tiempo (Camino Mayor, J. y Viniegra Pacheco, Y., 1996). 
muestra escasamente significativa de cerámicas finas anaranjadas. En los niveles de ocupación más antiguos (nivel XVI) se asocian las cerámicas incisas (verticales y entrecruzadas) con las reticuladas y pintadas sin que, como en el caso de Corao, se aprecie una clara evolución de la incisión vertical a la retícula y la decoración pintada. Este nivel de Villanueva se ha fechado radiométricamente entre la 2. ${ }^{a}$ mitad del siglo IX y principios del $\mathrm{X}^{37}$, y es posterior a las estructuras originarias del yacimiento ${ }^{38}$.

\begin{tabular}{|c|l|c|}
\hline \multicolumn{2}{|c|}{ MONASTERIO DE SAN PEDRO DE VILLANUEVA } \\
\hline \multicolumn{2}{|c|}{ Decoración } & Producciones altomedievales \\
\hline B-1 Incisa & $\%$ \\
\hline b1-1 & Ondas incisas & $18 \%$ \\
\hline b1-2 & Peine vertical & $35 \%$ \\
\hline b1-3 & Líneas incisas entrecruzadas & $20 \%$ \\
\hline b1-4 & Retícula incisa & $22 \%$ \\
\hline B-2 & Pintada & \\
\hline
\end{tabular}

\subsubsection{Fortaleza de Peñe Manil (Cebia, Cangas de Onis)}

Los materiales proceden de una prospección superficial de la zona sin que se puedan establecer, por tanto, conclusiones con criterio estratigráfico. Aun así, se puede inferir una aproximación cronológica en función de paralelismos técnicos y formales con los otros yacimientos estudiados.

\begin{tabular}{|r|l|c|}
\hline \multicolumn{2}{|c|}{ FORTALEZA DE PEÑE MANIL } \\
\hline \multicolumn{2}{|c|}{ Decoración } & Recogida superficial \\
\hline B-1 Incisa & $\%$ \\
\hline b1-1 & Ondas incisas & $33 \%$ \\
\hline b1-2 & Peine vertical & $33 \%$ \\
\hline b1-3 & Líneas incisas entrecruzadas & $33 \%$ \\
\hline b1-4 & Retícula & $0 \%$ \\
\hline B-2 & Pintada & $0 \%$ \\
\hline
\end{tabular}

37 M1: 894 - 1172 AD. CAL. 1 SIGMA. CSIC. Madrid.

${ }^{38}$ En algunos sectores (Sala E y Huerta del Cura) se documentó un nivel de limos y arcillas de color marrón claro (XVII), removilizado con restos constructivos, tejas y argamasas, y algunos fragmentos cerámicos (toscos, porosos, acastañados) fechado también radiométricamente (M4: 887 - 1012 CAL. 1 SIGMA). Estos materiales están en relación con los localizados junto al yacimiento de Corao (corte B) e identificados como de tradición de la Edad de Hierro (ver nota 49). 
3.1.4. Fortaleza de la Porra Portiella (Següenco, Cangas de Onís)

Como en el caso anterior, los materiales proceden de una prospección superficial y la aproximación cronológica se ha realizado también en base a paralelismos técnicos y formales con los otros yacimientos estudiados. Es el único yacimiento en el que se han identificado fragmentos con decoración estriada horizontal, en relación con la de los yacimientos cántabros y palentinos ${ }^{39}$.

\begin{tabular}{|c|l|c|}
\hline \multicolumn{2}{|c|}{ FORTALEZA DE PORRA PORTIELLA } \\
\hline \multicolumn{2}{|c|}{ Decoración } & Recogida superficial \\
\hline B-1 & Incisa & $\%$ \\
\hline b1-1 & Ondas incisas & $0 \%$ \\
\hline b1-2 & Peine vertical & $48 \%$ \\
\hline b1-3 & Líneas incisas entrecruzadas & $0 \%$ \\
\hline b1-4 & Retícula & $45 \%$ \\
\hline b1-5 & Estriada horizontal & $7 \%$ \\
\hline B-2 & Pintada (tardía) & 40 \\
\hline
\end{tabular}

\subsubsection{Necrópolis de la Ermita de Santa Cruz (Vega de Contranquil, Cangas de Onís)}

Los materiales cerámicos proceden del nivel más antiguo, Ilc, que se corresponde con el horizonte de la primera fase de enterramientos. Se observa un dominio absoluto de la decoración incisa vertical a peine y ausencia de pintadas y retícula incisa.

\begin{tabular}{|c|l|c|}
\hline \multicolumn{2}{|c|}{ NECRÓPOLIS ERMITA DE SANTA CRUZ } \\
\hline \multicolumn{2}{|c|}{ Decoración } & Fase I. Nivel Ilc \\
\hline B-1 & Incisa & $0 \%$ \\
\hline b1-1 & Ondas incisas & $0 \%$ \\
\hline b1-2 & Peine vertical & $80 \%$ \\
\hline b1-3 & Líneas incisas entrecruzadas & $20 \%$ \\
\hline b1-4 & Retícula incisa & $0 \%$ \\
\hline B-2 & Pintada & $0 \%$ \\
\hline
\end{tabular}

39 Porra Portiella es el único yacimiento en el que se ha identificado con claridad este tipo de decoración: estrías horizontales bien definidas con punzón fino de sección rectangular sobre pastas grises finas de buena calidad. La decoración estriada está escasamente representada en Asturias, donde se ha registrado en Gijón (Encinas Martínez, M. y Fernández Ochoa, C., 1986: ${ }^{347)}$; al igual que en León y es característica de los yacimientos cántabros y palentinos (siglos VIII-pios. XI) (Gutiérrez, J. A. y Benéitez, C., 1989: 230).

40 Ver nota 57. 


\subsection{Producciones cerámicas}

\section{A. Cerámicas de tradición romano tardía (cerámicas «residuales»)}

Hay que advertir que la muestra no es en absoluto significativa pero, aún así, tiene el valor de testimoniar la presencia de este tipo de producciones en una zona inédita hasta ahora y permite relacionarlas o vincularlas con otros testimonios de la cultura material de la zona como son las estelas vadinienses y los jarritos visigodos ${ }^{41}$.

\section{A-1 y A-2. Terra Sigillata Hispánica Tardía (TSHT) y Cerámicas Anaranjadas (ss. IV-V)}

Se han documentado únicamente en Corao y Villanueva. En Corao, en el nivel IV de la Estructura 1 se registró un pequeño fragmento de TSHT (muy pequeño, apenas $1 \mathrm{~cm}$, y muy rodado) así como una pequeña muestra de 3 fragmentos de cerámicas finas anaranjadas. En Villanueva, en el suelo de ocupación más antiguo se documentó también una pequeña muestra, aunque escasamente significativa, (SPV95-II1,59-211) de pasas finas anaranjadas. Son pastas bien cocidas a fuego oxidante y de tonalidades anaranjadas, asimilables a las producciones de cerámica común romana, bien documentadas en las villae del sector centro-oriental asturiano.

\section{A-3. Ollas de borde plano inciso (ss. V-VIII)}

Aunque se ha identificado un único fragmento recogido en superficie en Corao, la pieza tiene gran interés por las implicaciones cronológico culturales que supone.

Son producciones de cerámica común inspirada o derivada de los «cuencos de borde horizontal», Tipo 4 de M. Vegas (Vegas, M., 1973: 20, fig. 5): cuencos bastantes profundos y de fondo curvo. Su función es idéntica a la de las ollas, diferenciándose únicamente en que mientras en éstas el diámetro mayor es el de la panza, en aquellos el diámetro de la boda es similar al de las paredes. Se trata de un tipo de olla de base plana, cuerpo elipsoidal poco saliente, con tendencia a la forma cilíndrica y borde plano horizontal. La pasta es de regular calidad, porosa, rugosa y con abundantes desgrasantes cuarcíticos y micáceos de pequeño tamaño. Ejecutada a torneta y cocida a fuego reductor (Modo B). El elemento distintivo (aunque el ejemplar de Corao no lo conserva, probablemente por estar muy rodado) son las incisiones que decoran el borde y que definen motivos bastante varia-

41 No se han registrado en el sector oriental de Asturias producciones incisas y estampilladas —bien documentadas sin embargo en el sector central de la región-en relación con las definidas como grupo final o visigodo de las imitaciones/derivaciones de las sigillatas tardías galas y africanas (Terra Sigillata Hispánica Tardía Imitación Paleocristiana), datadas entre los siglos V y VII (Caballero, L., 1985: 118), que otros autores han denominado cerámicas estampilladas tardorromanas (Cerrillo, E., 1976: 459), y cerámica tardorromana visigoda con decoración estampada (Mañanes, T., 1980: 3). En Asturias parecen circunscribirse con exclusividad al sector central de la región (Encinas Martínez, M. y García Carrillo, A. 1992: 131-139; Requejo Pagés, O., 1992: 140-146; Fernández Ochoa, C. y Zarzalejos, M., 1997: n. ${ }^{\circ} 59$ y 60 , fig. 26). 
dos: trazos rectos, sinuosos u ondulantes aunque en las piezas más tardías, el motivo más común son las incisiones a peine, marcas incisas que han sido interpretadas como medidas de capacidad (Martínez Salcedo, A., 1998-99: 161-182; Aguarod, C., 1991: 99-102).

Es un tipo frecuente en Asturias en contextos arqueológicos variados de cronología romana y con una amplia dispersión geográfica en la región: se han localizado ejemplares en las Termas, fábrica de Salazones y muralla de Gijón; en las villae de Beloño (Gijón), Paraxuga (Oviedo), Puelles (Villaviciosa), Andallón (Las Regueras); también en yacimientos castreños: Campa Torres (Gijón), San Chuis (Pola de Allande) Arancedo (El Franco), y en cuevas: la Lloseta y les Pedroses (Ribadesella) $^{42}$ (Maya, J. L., 1977: 823-834; Fernández Ochoa, C., 1982: 160-161; 1994: 70-71, fig. 20,21). Su dispersión geográfica sobrepasa el ámbito costero cantábrico, al valle del Ebro y suroeste francés y se han interpretado como envases de productos para su comercialización (Fernández Ochoa, C. y Zarzalejos, M., 1997: 96-101). Cronológicamente se tata de un tipo con larga perduración en el tiempo puesto que ya se conoce en el siglo I. d.C. aunque abundan sobre todo en los niveles de cronología tardorromana ${ }^{43}$ y está en relación con la cerámica micácea basta de cronología visigoda de los siglos V-VIII (Caballero, L., 1985: 118).

\section{B. Cerámicas altomedievales (ss. Vill-X)}

Las producciones altomedievales son el resultado de la tradición precedente (en el caso de la incisión) y se insertan también en las tradiciones vigentes en la Meseta norte y Cantabria, aunque con matices. La técnica y motivos decorativos han sido el criterio utilizado para la discriminación de los diferentes grupos o producciones cerámicas; además de ser un criterio eficaz, se ha considerado una cuestión de orden práctico ya que de esta manera se pueden asociar o asimilar a otros grupos definidos en estudios precedentes y ampliamente aceptados en la bibliografía arqueológica.

\section{B-1. Cerámicas con decoración incisa}

\section{B1-1. Ondas}

Constituyen un grupo minoritario y se documenta únicamente en el nivel más antiguo de Corao, San Pedro de Villanueva y Peñe Manil en porcentajes muy

42 Un estudio en profundidad de este tipo ha sido realizado por Fernández Ochoa, C. y Zarzalejos, M., 1997: 96-101.

${ }^{43}$ Estas cerámicas se relacionan con las del tipo 7a de Monte Cildá (Olleros de Pisuerga, Palencia) estudiadas por García Guinea y otros: «cerámica oscura micácea», cronológicamente encuadrada entre los siglos V y VIII d.C. (García Guinea, M. A., González Echegaray, J. y Sanmiguel Ruíz, J. A., 1966), y también con los «tipos cerámicos con más arena y mica» que proliferan en la Meseta a partir de la $2 .^{a}$ mitad del s. V d.C., según el esquema propuesto por T. Mañanes (1980: 29) y que L. Caballero considera grupo terminal de la producción cerámica que él define como «Terra Sigillata Hispánica Tardía Imitación Paleocristiana» y cuya cronología es visigoda (Caballero, L. 1985: 97-127). 
bajos (apenas el 5\%) y asociada a peine vertical y líneas entrecruzadas. En los casos en que ha sido posible identificar la forma se trata de ollas de cuello corto vertical o ligeramente exvasado y labio redondeado. Son pastas de calidad media y buena, con desgrasantes cuarcíticos de pequeño tamaño y ocasionalmente partículas micáceas. Están ejecutadas a torneta y cocidas a fuego reductor (Modo B).

En el contexto asturiano, se ha registrado en Gijon en niveles tardoantiguos (Fernández Ochoa, C; García Díaz, P. y Uscatescu, A., 1992: fig. 16; Fernández Ochoa, C. y Zarzalejos, 1997: 105, fig. 20-12) y es el tipo más abundante entre las producciones de cerámica común de las villae de Murias de Beloño (Gijón), asociado a ollas y jarras ${ }^{44}$ y de Murias de Paraxuga (Oviedo), en cuencos y ollas (Requejo Pagés, O., 1992: 140-146). En ambos casos aparece en relación con producciones de TSIPIP (Terra Sigillata Hispánica Tardía Imitación Paleocristiana) y derivaciones, datadas entre los siglos V y VII.

Con ligeras variaciones formales, y también técnicas, hay que relacionarlo con las producciones altomedievales del nivel más antiguo de la catedral de Oviedo ${ }^{45}$ y las estudiadas por M. Encinas: Grupo 1 (s. VIII-X) de las cerámicas «prerrománicas» de Peñón de Raíces, Castillo de Tudela y y el Grupo A establecido por el mismo autor para las producciones del Monasterio de San Pelayo fechadas a mediados del siglo X (Encinas Martínez, M., 1986: 315, Grupo 1, lám. I-1,2 y 3; Encinas Martínez, M., 1987: 386-392). Se ha registrado también en el yacimiento de Solavilla (Sariego) (Estrada, R., García de Castro, C. y Villa, A., 1992: 246, lám. I12), en Peña Castiello (Villaviciosa) (Chao, F. J., Busto, M. y Fao, M., 1992: 200206) y en la fase más antigua del Castilo de Curiel (Peñaferruz, Gijón) (Gutiérrez, J. A., 2003: 196-197; 205-207), cronología que se confirma en paralelos extrarregionales como Monte Cildá y El Castellar (Palencia) ${ }^{46}$.

Por tanto, aunque tiene su origen y apogeo en época romano tardía, se trata de un tipo con una larga perduración en el tiempo, hasta por lo menos mediados del siglo $X$, y representan muy bien el periodo de transición de la Antigüedad tardía (siglos V-VII) a la Alta Edad Media (siglos VIII-IX).

\section{B1-2. Peine vertical}

La calidad de las pastas es similar a las del apartado anterior: son pastas de calidades regulares, toscas, duras, con abundantes desgrasantes cuarcíticos de tamaño pequeño y medio y ocasionalmente micáceos y chamota. Están ejecutadas

\footnotetext{
44 Encinas Martínez, M. y García Carrillo, A., 1992: 131-139. Un estudio detallado de estas cerámicas procedente de la villa de Beloño (localizadas en los fondos del Museo Arqueológico provincial sin ninguna referencia estratigráfica), nos ha permitido discriminar varios grupos dentro de esta producción cerámica, las más abundante y representativa de este yacimiento: MB1-MB-76. O. Requejo Pagés (inédito).

45 Nivel prerrománico, siglos VIII-X (Olávarri, E., 1970, inédito).

${ }^{46}$ García Guinea, M. A., González Echegaray, J. y Sanmiguel Ruiz, J. A., 1966: 134, fig. 7 y García Guinea, M. A., Iglesias, J. M. y Caloca, P., 1973; García Guinea, M. A., González Echegaray, J. y Sanmiguel Ruiz, J. A., 1963; Bohigas, R. y Ruiz, A., 1989: 3151.
} 
a torneta y las cocciones son mayoritariamente reductoras, reductoras deficientes y ocasionalmente oxidantes con postcocción reductora (Modos B y D). Las tonalidades son grisáceas y beige-blanquecinas ${ }^{47}$.

Formalmente se trata de ollas, mayoritariamente, y jarras (1 ejemplar en Villanueva), con cuellos cortos verticales o ligeramente exvasados y labios redondeados o ligeramente apuntados. Decoraciones con líneas incisas verticales trazadas a peine en el cuello y la panza. La decoración se obtiene aplicando sobre la pasta tierna un punzón, peine o cualquier otro instrumento que produce estrías o surcos según la sección del filo (en arista o romo). Estas cerámicas son las más abundantes en las fases más antiguas de Corao (N IV) - siendo minoritarias en la fase posterior-, y Santa Cruz (N IIc). Están presentes en Villanueva pero en minoría respecto a las pintadas y reticuladas, al igual que en Peñe Manil, y ausentes en Porra Portiella.

Estas son las cerámicas altomedievales por excelencia, con una dilatada vigencia cronológica: se documentan en la práctica totalidad de yacimientos de cronología medieval y en variados contextos y se trata de un tipo genuinamente asturiano (Gutiérrez, J. A. y Benéitez, C., 1989: 229). Las cerámicas con decoración incisa de líneas verticales fueron individualizadas como producciones cerámicas altomedievales por M. Encinas en su estudio sobre los materiales de las fortalezas de Raíces (Castrillón), Tudela (Oviedo) (Encinas Martínez, M., 1986: 307-328) y Monasterio de San Pelayo (Oviedo) (Encinas Martínez, M., 1987: 386-392).

Los grupos caracterizados por la decoración de líneas verticales incisas a peine, anchas y profundas se fechas en torno al siglo $X$ y son dos: el 3 de Raíces y C de San Pelayo, y el 5 de Raíces y D de San Pelayo. En San Salvador de Valdedios, en el repertorio formal del conjunto más antiguo (grupo 3), fechado en los siglos IX-X, dominan las incisiones verticales «a peine» $\mathrm{y}$, en menor medida, las entrecruzadas con líneas horizontales (Requejo, O., Martínez, A, y Jiménez, M., 1990: 187; Requejo, O., 1998: 19-26).

Se observan variaciones formales y técnicas entre las producciones del sector central y oriental (en el sector central, tendencia a la oxidación y el oriente a la reducción) y también en la calidad de las pastas (lo que se explicaría por la utilización de arcillas locales), pero no en las técnicas decorativas, incisión vertical a peine, que, en todos los casos, aparece asociadas a líneas incisas entrecruzadas.

\section{B1-3. Líneas incisas entrecruzadas}

Pastas de calidad media y regular, con abundantes desgrasantes cuarcíticos de pequeño y mediano tamaño. Ejecutadas a torneta y con acabado imperfecto. Cocciones mayoritariamente reductoras (Modo B) y tonalidades grisáceas; en el

47 Se han hecho ensayos de cocción de arcillas de la zona a distintas temperaturas y en distintas atmósferas y las tonalidades resultantes son en la totalidad de los casos entre el beige y el blanquecino. 
caso de Corao, beige-blanquecinas y engobe beige en la cara externa. Se relacionan con el grupo 3 de de Valdedios, fechado en los siglos IX-X, donde, al igual que en los yacimientos de Cangas y del sector central, aparece asociado a la incisión a peine.

Aunque resulta complicado definir los motivos decorativos con precisión debido al estado fragmentario de las piezas, éstos se concretan fundamentalmente en:

- Líneas verticales cortadas por líneas horizontales/oblicuas aisladas.

- Líneas verticales cortadas por líneas horizontales/oblicuas sin formar retícula.

B1-4. Retícula incisa

Pastas de buena calidad, con finos desgrasantes cuarcíticos. Duras y de sonido metálico. Ejecutadas a torneta y cocciones mayoritariamente reductoras y también reductoras con postcocción oxidante (Modos A y B); tonalidades grises y beige-grisáceas. Decoradas con líneas incisas entrecruzadas formando retícula:

- Líneas verticales cortadas por líneas horizontales/oblicuas formando retícula.

- Líneas verticales cortadas por series de bandas de líneas horizontales formando retícula/damero.

Se trata de una decoración con una amplia dispersión en la región Asturiana, Meseta Norte y Cantabria. La retícula incisa se considera un tipo de decoración genuinamente leonés, con momento de apogeo en el siglo XII, aunque se presuponía un origen anterior (Gutiérrez, J. A. y Beneitez, C., 1989: 229 y 237), y su presencia se constata en contextos asturianos altomedievales ${ }^{48}$.

En un primer momento, aunque en menor proporción, la retícula aparece asociada a la decoración incisa a peine, para pasar a ser dominante junto con las cerámicas pintadas en una fase posterior, a partir de los siglos IX-X: la retícula está ausente en los niveles más antiguos de Corao (IV) y Santa Cruz (IIc). En Corao se constata en el nivel siguiente (III), asociada a las pintadas al igual que ocurre en San Pedro de Villanueva. En Valdedios se documenta en el nivel más antiguo (Vb), pero pasa a ser dominante en el nivel superior (Va), fechado en los siglos X-XI, donde aparecen asociadas a un fondo de base con una cruz inscrita ${ }^{49}$, y aunque las incisiones verticales también se mantienen, están presentes en menor proporción.

48 Se documenta en el nivel más antiguo de la Catedral de Oviedo (VIII-X): Olávarri, E., 1970; en las producciones del grupo 2 de Raíces y B de San Pelayo definido por M. Encinas y que el autor sitúa en el siglo X (Encinas, M., 1986 y 1987); En Cantabria también se registra en contextos tempranos (siglos VIIIX) (García Guinea, M. A. et alii, 1966: fig. 7, lám. XV-XVI).

49 Paralelos en Cantabria, León, Zamora y Palencia (VV.AA., 1989: 309). 
Su registro en la zona de Cangas, con materiales en posición estratigráfica y dataciones radiométricas, confirma su cronología altomedieval.

\section{B-2. Cerámicas pintadas (ss. IX-X)}

Constituyen sin duda el lote más interesante, por lo novedoso y numeroso de la muestra y por su registro en posición estratigráfica. Están presentes en la segunda fase de Corao y en Villanueva y ausentes en Santa Cruz, Peñe Manil y Porra Portiella, lo que contribuye a aumentar el mapa de dispersión de estas producciones en el contexto regional, donde hasta ahora se habían registrado únicamente fragmentos escasos y de reducido tamaño ${ }^{50}$.

Las pastas presentan calidades medias, con abundantes desgrasantes cuarcíticos de pequeño y mediano tamaño; están ejecutadas a torneta y con acabado imperfecto. Formalmente se asocian a ollas/jarras de cuello largo vertical y labio estrecho, ligeramente apuntado ${ }^{51}$. Las tonalidades beige-blanquecinas de las pastas, de acuerdo con los ensayos de cocción realizados, se producen en las arcillas locales tanto en reducción como en oxidación ${ }^{52}$, aunque en las producciones pintadas estudiadas en yacimientos cántabros y palentinos se constata la tendencia a la oxidación (Modo C) ${ }^{53}$.

La decoración pintada es de tonalidad marrón rojiza. Se trata de pigmentos aplicados a pincel antes de la cocción y los colorantes son óxidos: rojo ${ }^{54}$ (Óxido férrico: $\mathrm{Fe} 2 \mathrm{O} 3$ ); negro (Óxido ferroso: $\mathrm{FeO}$ ) y marrones (Óxido de Manganeso) (Fernández. Chiti, J., 1980: 98). Los motivos decorativos son bastante homogéneos y están en clara relación con los de la decoración incisa: ondas y reticulados, localizándose preferentemente las ondas en el cuello y el enrejado/reticulado en la mitad superior del cuerpo.

50 Finca de Solavilla (Santianes, Sariego): pastas ocres, anaranjadas y blanquecino-amarillentas; motivos pintados en rojo y negro con puntos y líneas (Lám. II, 1,2 y 3); uno de los fragmentos (40: II,3) presenta la decoración sobre engobe grisáceo. Datadas entre los siglos VIII-X (Estrada, R., García de Castro, C. y Villa, A., 1992: 243-251, lám. II, 1,2 y 3).

Picu Torres (Ribadesella): 1 fragmento con motivo pintado en rojo, fechado entre los siglos XI-XIII (Álvarez Estrada, F. y Moure, J. A., 1985: 113 y Fernández. Conde, J., 1989: 187, fig. XI,1; el dibujo resulta poco preciso y expresivo). Quizá habría que retrasar las fechas y datarlas entre los siglos IX y X.

Cueva de El Soberau o Los Furacaos, Puertas (Cabrales). Referencias al hallazgo en superficie de un fragmento de pasta clara con motivo enrejado vinoso. Siglo VIII-X (paradero desconocido).

Santa María de Tina (Ribadedeva): dos fragmentos de formas globulares con pintura color castaño sobre engobe blanco, fechados en los siglos XI-XII (Fernández Conde, 1989: 184, fig. IX,1).

San Salvador de Valdedios (Villaviciosa): 1 fragmento pintado de pasta blanquecina pintada en negro sobre engobe blanco (grupo II, tipo V), datado entre los siglos XII y XIII (Argüello Suárez, A., 1992: 221, Foto II).

51 El estado fragmentario de la muestra impide la reconstrucción formal en la mayoría de los casos.

52 Sería interesante localizar el centro de producción para comprobar el comportamiento de la materia prima.

53 Bohígas, R. y G. ${ }^{\circ}$ Camino, I., 1987: 122-124; Bohígas, R. y Sarabia, P., 1987: 313-325, fig. II,1, 2 , $7,13,15,32-40$ y 44 y fig. II, 15).

54 En cocción oxidante, los óxidos de hierro provocan que, al elevar las temperaturas, el rojo se vuelve castaño, achocolatado e incluso negruzco. 
Tabla 3. Motivos decorativos pintados

\begin{tabular}{|c|l|c|}
\hline \multicolumn{1}{|c|}{ Motivos decorativos } & Yacimiento \\
\hline 1 & líneas verticales combinadas con líneas de puntos verticales & SPV y Co \\
\hline 2 & $\begin{array}{l}\text { líneas verticales cortadas por líneas horizontales formado un motivo de } \\
\text { enrejado o retícula }\end{array}$ & SPV y Co \\
\hline 4 & líneas onduladas enmarcadas entre líneas horizontales & SPV \\
\hline 5 & bandas de motivos horizontales en forma de Y invertida & SPV \\
\hline 6 & $\begin{array}{l}\text { líneas incisas horizontales y líneas pintadas oblicuas (novedoso por la } \\
\text { combinación de ambas técnicas) }\end{array}$ & L P55 \\
\hline
\end{tabular}

Los precedentes de estas producciones hay que buscarlos en época romana y visigoda. En Asturias las cerámicas pintadas de cronología romana más próximas a la zona de Cangas se localizan en el sector central, en Gijón y su entorno: se han documentado materiales fechados entre los siglos III y $V$ en la fábrica de salazones $^{56}$, la muralla (Fernández Ochoa, C. y Zarzalejos, M., 1997: n. ${ }^{\circ} 198,199$ y 200, fig. 41), Veranes ${ }^{57}$, Murias de Beloño y en Lugo de Llanera ${ }^{58}$. No se conocen hasta la fecha cerámicas pintadas de cronología visigoda cuyos yacimientos de referencia para su estudio son los palentinos y cántabros ${ }^{59}$. En esta área geográfica la tradición de la cerámica pintada de la 2. ${ }^{a}$ Edad del Hierro, "cantabro-vaccea», se mantiene en el Bajo Imperio y perdura hasta por lo menos el siglo VIII60. A partir de este momento se expande y alcanza gran desarrollo con el proceso repoblador,

55 La muestra de Porra Portiella, donde se ha registrado un único fragmento, plantea problemas de interpretación puesto que, técnica y decorativamente, es muy diferente a las piezas pintadas de Villanueva y Corao. La pasta es regular, cocción oxidante, color rosado y está ejecutado a torneta y decorado con técnica incisa y pintada (líneas incisas horizontales y líneas pintadas oblicuas de tonalidad grisácea azulada). La combinación de ambas técnicas es característica del yacimiento cántabro de El Torrrejón de las Henestrosas, donde las formas características son piezas globulares con decoración pintada (ondas y enrejados) y estriada (dominante), en menor proporción ondas incisas e importaciones esmaltadas. Se fechan en los siglos XIII-XIV. Además, Porra Portiella es el único de los yacimientos estudiados que ha proporcionado cerámicas estriadas (Bohígas, R. y Sarabia, P., 1987: 454; Bohígas, R., Andrio, J., Peñil, J. y García, M., 1989: 124).

56 Fernández Ochoa, C., 1994: 53 y fig. 10, n. $^{\circ} 48,49,50$. Se trata de un fragmento de olla y dos fuentes y otros fragmentos no identificados formalmente, con decoración oscura (pardo oscura, negra o vinosa) son motivos geométricos.

57 Olmo Enciso, L., 1984: 87, n. 122 y 123. Se trata de dos fragmentos de cerámica pintada que se sitúan en época bajo imperial (siglos IV-V) Son cocciones oxidantes y pastas ocres, decoradas con tonos pardos y anaranjados con trazos horizontales y motivos reticulados.

58 Requejo Pagés, O. (Inédito): Estudio cerámico de los yacimientos de Murias de Beloño y Lugo de Llanera: MB 138 (fragmento de jarra de pasta rosada y decoración pintada enrojo con puntos y líneas oblicuas); MB 208 (fragmento de jarra cocida a fuego reductor y pintada con motivos geométricos de tonalidad blanquecino-amarillenta) y LL66 (fragmento de pasta reductora, decorado con dos líneas pintadas de color amarillo).

59 El Castellar (V-VII) (García Guinea, M. A. et alii, 1963: fig. 25-35); Cueva de Suano (s. V-VII) (Bohigas, R. y Ruiz, A., 1989: 32, fig. 1, n. ${ }^{19-20)}$ y primera fase de Monte Cilda (s.VI-VIII) (García Guinea, M. A. et alii, 1966; García Guinea, M. A. et alii, 1973; Peñil, J., Bohigas, R. y Jimeno, R., 1986: 227.

60 Son producciones (cuencos, platos y ollas) pintadas con pigmentos de tonalidad rojiza u ocre y con motivos de trazos verticales paralelos y enrejados. Aparecen asociadas a cerámicas estriadas y decoración incisa de ondas. 
Tabla 4. Producciones cerámicas: contextos arqueológicos y cronología

\begin{tabular}{|l|c|c|c|c|c|c|c|c|}
\hline \multicolumn{1}{|c|}{ Yacimiento } & Siglos IV-V & \multicolumn{3}{|c|}{ Siglos VI-VIII } & \multicolumn{2}{c|}{ Siglos VIII-IX } & \multicolumn{2}{c|}{ Siglos IX-X } \\
\hline & A1 & A-2 & A-3 & B-1-1 & B-1-2 & B-1-3 & B-1-4 & B-2 \\
\hline 1. Corao & T.S.H.T. & $\begin{array}{c}\text { Plano } \\
\text { inciso }\end{array}$ & $\begin{array}{c}\text { Finas } \\
\text { anaran- } \\
\text { jadas }\end{array}$ & Ondas & $\begin{array}{c}\text { Peine } \\
\text { vertical }\end{array}$ & $\begin{array}{l}\text { Incisiones } \\
\text { cruzadas }\end{array}$ & Retícula & Pintadas \\
\hline 2. Villanueva & - & - & $\begin{array}{c}\text { Finas } \\
\text { anaran- } \\
\text { jadas }\end{array}$ & Ondas & $\begin{array}{c}\text { Peine } \\
\text { vertical }\end{array}$ & $\begin{array}{c}\text { Incisiones } \\
\text { cruzadas }\end{array}$ & Retícula & Pintadas \\
\hline 3. Peñe Manil & - & - & - & Ondas & $\begin{array}{c}\text { Peine } \\
\text { vertical }\end{array}$ & $\begin{array}{l}\text { Incisiones } \\
\text { cruzadas }\end{array}$ & Retícula & Pintadas \\
\hline 4. Porra Portiella & - & - & - & - & $\begin{array}{c}\text { Peine } \\
\text { vertical }\end{array}$ & $\begin{array}{l}\text { Incisiones } \\
\text { cruzadas }\end{array}$ & - & - \\
\hline 5. Santa Cruz & - & - & - & - & $\begin{array}{c}\text { Peine } \\
\text { vertical }\end{array}$ & $\begin{array}{l}\text { Incisiones } \\
\text { cruzadas }\end{array}$ & - & - \\
\hline
\end{tabular}

Tabla 5. Caracterización de las producciones cerámicas

\begin{tabular}{|l|l|l|l|l|}
\hline Producción & Pasta & Desgrasante & Factura & Cocción \\
\hline Finas anaranjadas & Buena-Fina & cuarcítico & Torno & Modo C \\
\hline Plano inciso & Regular-Porosa & $\begin{array}{l}\text { cuarcítico/micáceo } \\
\text { pequeño tamaño }\end{array}$ & Torneta & Modo B \\
\hline Ondas & Buena-Regular & $\begin{array}{l}\text { cuarcítico } \\
\text { pequeño tamaño }\end{array}$ & Torneta & Modo B \\
\hline Peine vertical & Regular-Tosca & $\begin{array}{l}\text { cuarcítico/micáceo// } \\
\text { chamota } \\
\text { pequeño tamaño }\end{array}$ & Torneta & Modos B - D \\
\hline Incisiones cruzadas & Regular & $\begin{array}{l}\text { cuarcítico } \\
\text { pequeño tamaño }\end{array}$ & Torneta & Modo B \\
\hline Retícula & Buena-Dura & cuarcítico finos & Torneta & Modos B - D \\
\hline Pintadas & Buena & $\begin{array}{l}\text { cuarcítico } \\
\text { pequeño tamaño }\end{array}$ & Torneta & Modo C \\
\hline
\end{tabular}

con apogeo en el siglo XI (Peñil, J., Bohigas, R. y Jimeno, R., 1986: 227-229). Las cerámicas del área de Cangas están en relación con las producciones altomedievales del núcleo cántabro-castellano, fechadas entre los siglos VIII-X y tradicionalmente denominadas Cerámicas de Repoblación ${ }^{61}$. El yacimiento tipo de este periodo es el Castillo de Camargo ${ }^{62}$, datado entre el siglo VIII y principios del XI; las

61 Para una síntesis y relación bibliográfica sobre las producciones pintadas de este periodo: Bohígas, R., Andrio, J., Peñil, J. y García, M., 1989: 126-127.

62 Bohígas, R. y G. ${ }^{\circ}$ Camino, I., 1987: 122-124; Bohígas, R. y Sarabia, P., 1987: 313-325, fig. II, 1, 2, $7,13,15,32-40$ y 44 y fig. II, 15. 
características de las producciones cerámicas son torno bajo, cocciones oxidantes y reductoras con dominio de las primeras y formas globulares; las técnicas decorativas son la incisión (ondas), el estriado (horizontal) y la pintura (con óxidos de hierro y motivos de ondas, haces de trazos paralelos y enrejados). Una fecha de C14 remite al reinado de Alfonso I (siglo VIII) y las primeras repoblaciones, por lo que la torre se vincula con el proceso repoblador de la costa cantábrica por este monarca ${ }^{63}$. En este contexto cronológico cultural se encuadrarían los yacimientos asturianos de la Vega de Corao y San Pedro de Villanueva.

\section{CONCLUSIONES Y REFLEXIONES}

Es preciso considerar en primer lugar las limitaciones del estudio de los materiales: hay que aludir a su estado fragmentario que dificulta, por un lado, el análisis formal pero, sobre todo, el análisis del repertorio decorativo (motivos, orientación...). En muchos casos resulta problemático determinar con precisión los motivos decorativos debido al tamaño y estado de los fragmentos y piezas consideradas con decoración a peine vertical u horizontal pudieran corresponder a piezas decoradas con líneas entrecruzadas o reticuladas. Esta dificultad se ha puesto de manifiesto en los estudios realizados sobre otras producciones cerámicas medievales (Gutiérrez, J. A. y Benéitez, C., 1989: 228).

Ello incide igualmente en las limitaciones del análisis porcentual realizado que se refiere a una pequeña muestra selecta de los materiales. Aún reconociendo y asumiendo tales limitaciones, ha resultado lo suficientemente expresivo y pone de manifiesto una constante en la evolución técnica en las producciones cerámicas de los yacimientos estudiados lo que permite inferir conclusiones generales.

Las limitaciones son también extensibles a los análisis técnicos, condicionados por la disponibilidad de medios técnicos y de financiación.

\subsection{Materia prima y ensayos de cocción en muestras de arcilla ${ }^{64}$}

Las cerámicas estudiadas son producciones locales elaboradas con arcillas calcáreas, ricas en carbonato cálcico $(\mathrm{CaO} 3)^{65}$. De manera genérica se clasifican como Cerámicas Calcáreas en referencia a la materia prima utilizada. Poseen cuarzo como componente, nunca mica, y pueden tener contenidos de hierro variables. En Asturias, las formaciones geológicas calizas se concentran mayoritariamente en el extremo oriental de la región, en terrenos cretácicos y, fundamen-

63 Bohígas, R. y Sarabia, P., 1987: 324. Como ya señalamos anteriormente (ver nota 84), la cerámica pintada de la Torre riosellana de Picu Torres podría encuadrarse en este momento.

64 Los análisis fueron realizados por Blanco, M., Sánchez, I. y Asperilla, H. R., 1996. También se realizaron nuevos ensayos de cocción en el año 2000 en el taller de Maximino Blanco del Dago en La Riera, Covadonga, a quien agradecemos su desinteresada colaboración.

65 Picon, M., 1984: 103 y nota 1. 
talmente, terciarios. La tradición alfarera se concentra, precisamente, en la franja de Oviedo a Cangas de Onís, en terrenos del Terciario y Cretácico, donde las prospecciones de los estudios Geológicos constatan el mayor número de explotaciones y los terrenos ofrecen materia prima más óptima ${ }^{66}$.

Con la finalidad de solventar la problemática de la interpretación de la coloración de las pastas y las técnicas de cocción, se realizaron una serie de ensayos de cocción de muestras de arcillas locales, en concreto de la zona de Pandesiertos, en Corao (Fig. 5).

La arcilla presentaba muchas impurezas y una coloración muy oscura, de color rojizo-ferruginoso por lo que a simple vista y en crudo la pasta parecía contener una elevada cantidad de hierro. Se trata de una arcilla muy plástica, imposible de trabajar sin la adicción de elementos desgrasantes.

Las muestras se cocieron a diferentes temperaturas en atmósfera tanto oxidante como reductora. Se cocieron un total de seis muestras: tres en ambiente reductor y tres en atmósfera oxidante, y a tres temperaturas distintas: $750^{\circ}, 1000^{\circ}$ y $1200^{\circ}$ para comprobar las características físicas de las arcillas cocidas en distintas atmósferas y a diferentes temperaturas. Las observaciones postcocción resultaron muy interesantes y clarificadoras:

- Cocción a $750^{\circ}$ : En oxidación la coloración de la pasta es de un ocre oscuro y en reducción de color ocre claro lo que desmiente que la pasta posea hierro y hace suponer que el color oscuro que se observa en la arcilla cruda sea materia orgánica. En esta temperatura la pasta es frágil y no ha llegado a vitrificar.

- Cocción a $1000^{\circ}$ : La coloración es, tanto en oxidación como en reducción, muy pálida, de color ocre. Esto certifica la ausencia de hierro y la existencia en la arcilla en crudo de materia orgánica. A la arcilla no le afecta una u otra atmósfera de cocción (así se comprueba cómo es básicamente la presencia de hierro la que posibilita los cambios de coloración según las atmósferas a las que se someten las arcillas). En esta temperatura la pasta aún no se observa vitrificada.

- Cocción a $1200^{\circ}$ : En oxidación se observan unas pequeñas motas que no aparecen en reducción (posiblemente estén provocadas por la reacción de algún mineral). El color sigue siendo muy claro en ambas atmósferas, ocre, ligeramente más oscuro en reducción.

Se constata que los tonos de la pasta, tanto en cocción reductora como en oxidante, son prácticamente idénticos, ligeramente más oscuros en reducción, pero siempre en tonalidades beige y blanquecinas-amarillentas. Estas tonalidades claras y uniformes se deben a la presencia de carbonato cálcico y al bajo contenido de hierro. Si contienen hierro, éste reacciona con otros componentes de la pasta

66 IMINSA, 1987. 


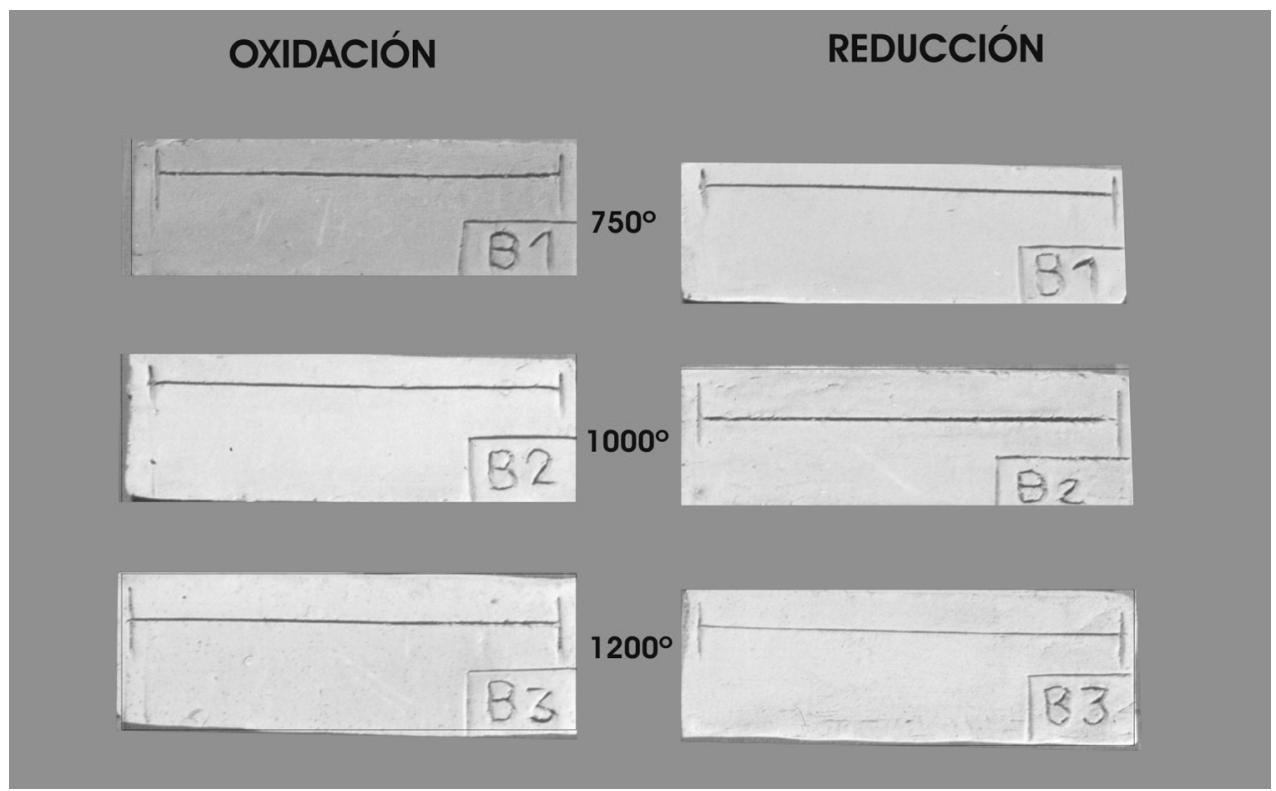

Fig. 8. Ensayos de cocción de muestras de arcillas.

(carbonato de cal) que suprimen el color (esto ocurre cuando el contenido de cal es superior al de hierro). También se puede concluir que son arcillas refractarias ya que a la máxima temperatura de cocción $\left(1200^{\circ}\right)$ no da muestras de fundirse.

\subsection{Características físicas y mineralógicas de las cerámicas ${ }^{67}$}

Estas producciones presentan unas características muy determinadas, diferentes a las estudiadas en otras zonas de la región: las texturas son más finas y los tonos, una vez cocidas, son claros, tanto en oxidación como en reducción.

Las limitaciones analíticas son evidentes puesto que solo se ha realizado un análisis mineralógico de una muestra cerámica ${ }^{68}$ pintada de San Pedro de Villanueva los minerales identificados proporcionan valiosa información sobre la composición y comportamiento de las arcillas y las temperaturas de cocción:

- Cuarzo: Es una de las variedades cristalinas de la sílice. Ejerce una acción fundamental en las pastas puesto que es el mejor y más poderoso antiplástico y aumenta la consistencia de la pieza horneada. Componente mineral de rocas graníticas y sedimentarias (pizarras, areniscas, calizas) por lo que puede estar presente en formaciones arcillosas en toda la región.

67 Con motivo de nuestra Tesis Doctoral se realizó la caracterización mineralógica de un conjunto de materiales cerámicos procedentes de distintos yacimientos de la región (Brime, C., 1999). Entre las muestras analizadas, dos procedían de San Pedro de Villanueva y de la vega de Corao.

${ }_{68}$ M21: fragmento con decoración pintada de San Pedro de Villanueva (V95-IV-1-28). 
- Feldespatos: Aluminosilicatos con contenido variable en sodio, potasio. Pueden mantenerse estables hasta temperaturas elevadas $\left(1200^{\circ}\right)$. Son minerales característicos de rocas graníticas y sedimentarias, por lo que, como el cuarzo, pueden estar presentes en formaciones arcillosas de toda la región.

- Hematites: Oxido de Hierro. Pueden existir en la pasta antes de la cocción y pueden ser también resultado de la transformación de la Goethita a partir de los $250-280^{\circ}$. Se añade a la pasta como fundente para que ésta se cueza a temperatura más baja.

- Mullita: Como mineral natural es raro. Es más frecuente como mineral de neoformación, es decir, formado artificialmente a determinada temperatura: se forma de manera artificial a partir de los $1000^{\circ}$ estando plenamente formada a los $1200^{\circ}$.

La caracterización mineralógica de las pastas cerámicas proporciona datos de interés sobre la temperatura de cocción de los materiales cerámicos ya que la presencia de mullita y feldespato indican unas temperatura entre $1000^{\circ}$ y $1200^{\circ}$. También permite concretar el área fuente de la materia prima utilizada en base a la presencia de determinados componentes y, por tanto, diferenciar producciones cerámicas locales y foráneas, aunque es preciso ampliar las muestras para confeccionar unas tablas de referencia sobre los yacimientos de la zona.

\subsection{Secuencia cronológico-cultural}

Una vez descritas y caracterizadas las producciones cerámicas se ha establecido un modelo de evolución de la secuencia cerámica basado en criterios estratigráficos y apoyado en dataciones radiométricas y en paralelos extrarregionales. La secuencia abarca desde la romanidad tardía (con evidencias testimoniales y residuales), hasta la Alta Edad Media.

El espacio geográfico de estudio es la comarca de Cangas de Onís, en concreto las vegas fluviales de los ríos Sella y Güeña, y afluentes tributarios, antiguo solar de los cántabros vadinienses en época romana; denominado Asturias en el siglo VIII y territorio premoriense o Primorias en las Crónicas de finales del siglo IX.

La secuencia cronológico-cultural se ha estructurado en cuatro fases caracterizadas cada una de ellas por distintas producciones cerámicas:

Fase 1 (s.IV-V): TSHT y cerámicas finas anaranjadas (residual)

Fase 2 (s.VI-VIII): plano inciso-ondas (residual)

Fase 3 (s.VIII-IX): peine vertical (dominante) y líneas incisas entrecruzadas-retícula (minoritaria)

Fase 4 (s.IX-X): peine vertical (minoritaria) y retícula - pintada (dominante) 


\section{- Fase 1 (siglos IV-V): TSHT -anaranjadas}

Las cerámicas de la fase 1 son residuales y poco significativas. Cronológicamente están en relación con las estelas vadinienses.

El solar de Cangas pertenecía en época romana al territorio de los cántabros que abarcaba el oeste del actual Principado de Asturias y Cantabria -excepto el extremo oriental-, el norte de Palencia y Burgos. Los grupos humanos que habitaban estas tierras pertenecían al ámbito los vadinienses, pueblo en expansión a ambos lados de la cordillera, a lo largo de los ríos Esla y Sella cuyo centro ha sido identificado tradicionalmente con el territorio de Cangas de Onís debido a la elevada concentración de estelas vadinienses funerarias en este territorio, fechadas entre los siglos II y IV d. C. Vadinia es citada en el siglo II d. C. por Ptolomeo (2.6.50) como ciudad cántabra, capital de los vadinienses, de localización imprecisa ${ }^{69}$. Más que a una ciudad o a un asentamiento, haría alusión a una población, dedicada a la agricultura nómada o seminómada y al pastoreo que acaba asentándose en un territorio al que dan su nombre ${ }^{70}$.

La presencia romana ha dejado vestigios en los testimonios epigráficos y en antiguos viales fundamentalmente, llamando la atención la falta de repertorios cerámicos y numerario de este periodo y también la ausencia de hábitats, en llano o en altura, lo que no se puede simplificar y explicar únicamente a partir del carácter nómada o seminómada de estas poblaciones ${ }^{71}$.

En época romana el paso sobre el Sella en Cangas era un punto estratégico de primer orden al ser nudo y cruce de comunicaciones con el eje trasversal norte-sur, que permitía el tránsito a las tierras leonesas. El territorio de Cangas también estaba vertebrado en su eje Oeste-Este por el tramo de la vía que desde Lucus Asturum (Llanera) se dirigía al Oeste a través del valle del río Güeña: Cangas de Onís-Celorio- Corao-La Estrada-por la margen izquierda del Güeña hacia Onís. Este antiguo viario romano será posteriormente el itinerario del Camino Real de Oviedo a Santander, conocido como Camino Antiguo. Fue recorrido por Ambrosio de Morales en el siglo XVI y Tirso de Avilés habla de «una columna de las que solían señalar millas», a la entrada del valle de $\mathrm{Corao}^{72}$ de donde salía un ramal en dirección a LLanes por la Sierra de Piedrahita. De esta calzada, que conserva tramos empedrados, da noticia Jovellanos ${ }^{73}$ y estaría en relación con los hallazgos epigráficos de LLenín y Villaverde y topónimos como La Estrada, entre Corao y Abamia, que también conserva tramos empedrados ${ }^{74}$.

69 Tabula imperii Romani. Hoja K-30: 230-233, voces: Vadinia, Vadinienses

70 El criterio de repartición de los territorios por Roma se realiza en función de las etnias (Tranoy, A., 1981: 153).

71 Los dos castros catalogados en la zona se localizan en Margolles, alejados de la zona de Corao: castros de El Cuetu, en El Llanu, (Martínez Villa, A., 1986) y El Cuetu, en Villa, (González y Fernández Vallés, J. M., 1966, 252-291). Al no haber sido excavados no se puede afirmar su filiación, aunque es probable que se trate de torres medievales.

72 Avilés, T., 1956: 160; Morales A. de, 1791: 203, cit. en: Diego Santos, F., 1985: 240).

73 Jovellanos, G. M. de, 1954: 129.

74 Tuvimos ocasión de recorrerlos con ocasión de nuestra colaboración en los trabajos de prospección arqueológica para la Memoria de Licenciatura de A. Martínez Villa (1986). 
Corao, por tanto, en la confluencia de los ríos Güeña y Chico, se perfila como un importante nudo de comunicaciones en la antigüedad y un espacio con una dilatado diacronía desde época prehistórica ${ }^{75}$.

El yacimiento en llano de la finca de San Nicolás, en la Vega de Corao, junto al río Chico, afluente del Güeña, constituye hasta el presente el único hábitat donde se han documentado evidencias de ocupación de cronología romano tardía (marginal y escasamente significativa pero testimonial), aunque la fase mejor representada corresponde al periodo de la corte de Cangas (siglo VIII) y a los siglos IX y X.

Es significativo el hiato que parecen evidenciar las producciones cerámicas (que no tiene refrendo en el registro epigráfico ya que de la veintena de lápidas vadinienses registradas en el concejo, 11 se han localizado en Corao) y que no puede interpretarse con el recurso al «vacío ocupacional», de difícil justificación en una zona con una dilatadísima secuencia diacrónica. Además, el interesantísimo lote de cerámicas localizadas en las proximidades de las estructuras en clara relación con las de la Edad del Hierro o, mejor, tradición del hierro, podría interpretarse como una tradición arcaizante mantenida en el seno de una sociedad tradicional. Cerámicas, por cierto, identificadas también —aunque de modo residual y escasamente significativas- en la fase constructiva más antigua de San Pedro de Villanueva. La dinámica fluvial y la proximidad de las estructuras de Corao al cauce del río pudieran explicar que sucesivas crecidas hubieran arrasado el registro arqueológico de los depósitos más antiguos como ha puesto de manifiesto el estudio geoarqueológico realizado en Villanueva. Ello no descarta que las lagunas o hiatos de determinados registros arqueológicos puedan ser consecuencia de vacíos en la investigación arqueológica y por la existencia de yacimientos aún inéditos.

\section{— Fase 2 (siglos VI-principios VIII): plano inciso-ondas}

Como en la fase anterior, el repertorio cerámico de este periodo es muy limitado y testimonial y se documenta nuevamente únicamente en Corao y Villanueva, en los niveles de ocupación más antiguos, y también en la torre de Peñe Manil.

Se relacionan con los materiales de origen visigodo documentados en la zona: los jarrillos de carácter ritual aparecidos en Covadonga y en la mina de El Milagro (Onís), cuya versión cerámica se interpreta en el ejemplar localizado en la Cueva de Avín, en Onís (fig. 9) ${ }^{76}$.

En el siglo $V$ nuevos acontecimientos afectan los territorios norteños cuando los bárbaros entran en la península en 409 y a mediados de siglo devastan Vasconia y saquean las costas cántabras. Desde finales de esta centuria y durante el siglo $\mathrm{VI}$ las fuentes silencian a cántabros y vascones lo que ha sido interpretado como signo de su independencia (Barbero, A. y Vigil, M., 1984: 51). A lo largo del siglo VII

\footnotetext{
75 Ver nota 1

76 La pieza, localizada en superficie en el interior de La Cueva el Molin, (Avín, Onís), ya había sido dada a conocer (Martínez, A. y Requejo, O., 1986: 335, ám. III, n. ${ }^{\circ} 1$ y 2); ahora se presenta su reconstrucción formal y dibujo más preciso.
} 

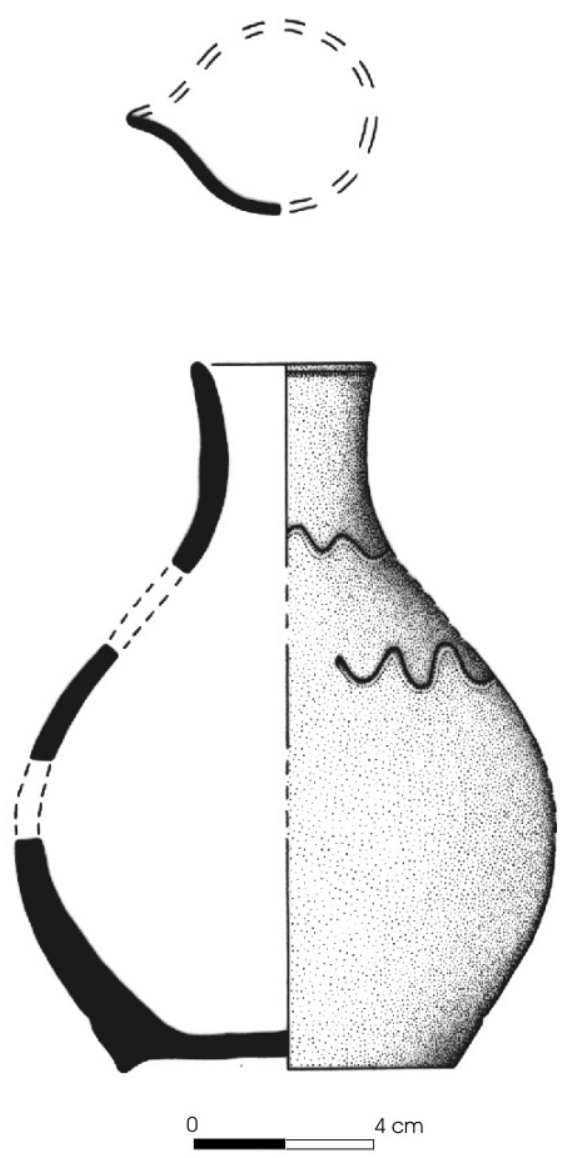

Fig. 9. Jarrita de Cueva el Molín, Onís.

las guerras de los visigodos con los pueblos del norte son frecuentes y se crea la provincia visigoda de Cantabria desde la que se combatirá a Astures y Vascones. Otros autores, sin embargo, defienden en el siglo VII la conquista de Asturias y Cantabria y su articulación en las estructuras político administrativas del reino visigodo lo que no habría sido incompatible con rebeliones contra el poder central ${ }^{77}$.

Lo cierto es que los cántabros desaparecen como pueblo independiente: los territorios de la antigua Cantabria romana pierden su nombre y sus habitantes serán llamados Astures a partir de entonces. Pelayo (718) es elegido, por tanto, en asamblea de Astures pero en territorio cántabro y el primitivo reino de Alfonso I (739), Asturias, coincidirá con los límites de la antigua provincia cantabra romana. No se puede precisar cuando se produce el desplazamiento (de Oeste a Este) de la denominación étnica - toponímica astur al occidente cántabro pues en época an-

77 Diversas opiniones al respecto son recogidas por J. I. Ruiz de la Peña (1995: 31 y nota 88). 
tigua los límites de los territorios son imprecisos y los nombres geográficos tienen un valor aproximado lo que da lugar a confusiones y desplazamientos ${ }^{78}$. Quizá pudiera explicarse por movimientos o desplazamientos de grupos de población (en este caso de Astures) durante el convulso periodo visigodo (siglo VII) o tras el episodio de 711, pues en época antigua son las poblaciones las que dan o fijan el nombre a los territorios (fenómeno constatado en el caso de los Vadinienses).

\section{- Fase 3 (siglos VIII-IX): - peine vertical - líneas incisas entrecruzadas (ma- yoritarias)$$
\text { - retícula - pintada (minoritarias) }
$$

Esta fase se caracteriza por el predominio de la cerámica decorada con incisiones verticales a peine, asociada a incisiones de líneas entrecruzadas, que se documentan en todos los yacimientos estudiados. Estas cerámicas son las más abundantes en las fases más antiguas de Corao (N IV) —siendo minoritarias en la fase posterior-, y Santa Cruz (N IIc). Están presentes en Villanueva pero en minoría respecto a las pintadas y reticuladas; también en Peñe Manil y ausentes en Porra Portiella, donde predomina la decoración estriada horizontal.

El siglo VIII es el periodo peor conocido, momento de transición y de cambio: en el momento de la insumisión de los Astures, es probable que en la zona de Cangas existiera un centro de poder político vinculado a Pelayo y quizá en relación con la estructura administrativa goda ${ }^{79}$. Las estructuras y depósitos arqueológicos más antiguos del asentamiento de San Pedro de Villanueva avalarían esta hipótesis. Cuando Alfonso I (739), hijo de Pedro, duque de Cantabria, viene a Asturias (como se denomina en el siglo VIII al espacio donde se localiza el núcleo de resistencia de Pelayo en Cangas), su reino coincidirá con los límites de la antigua provincia cantabra romana. La Influencia cántabra en la cultura material es incuestionable como pone de manifiesto la presencia de cerámicas pintadas - junto con las reticuladas- a partir del siglo VIII y con apogeo en los siglos IX-X. Esta influencia cántabra es el reflejo del peso político cántabro que supone el acceso de Alfonso I al trono de Cangas de Onís, primera corte del Reino de Asturias. Con este monarca el nuevo reino se expande a occidente y oriente $y$, a fines del siglo VIII, a pesar del traslado de la corte a Pravia por Silo (774), Cangas seguirá teniendo un protagonismo importante que mantendrá a lo largo de todo el periodo de la monarquía asturiana, durante los siglos IX y X.

- Fase 4 (siglos IX-X): - retícula - pintada (mayoritarias)

- peine vertical (minoritaria)

A partir de los siglos IX y $\mathrm{X}$ se impone claramente la decoración incisa reticulada y la pintada, como evidencian los registros de Corao y Villanueva, ausentes en Santa Cruz. La decoración incisa a peine se mantiene aunque en menor proporción.

${ }^{78}$ Ruiz de la Peña, J. I., 1995: 33-34 y notas 93 y 94). 
En el siglo IX, con el traslado definitivo de la Corte a Oviedo a partir de Alfonso II (791-842) y hasta Alfonso III (866-910), no se observan variaciones en la cultura material que sigue bajo la órbita cántabra. Durante los siglos IX-X Cangas seguirá siendo un importante referente a través del monasterio de San Pedro de Villanueva, solar de la primera corte del Reino de Asturias y centro de poder de la comarca durante siglos. La arqueología, por tanto, ha validado la tradición que remontaba su origen a los primeros años de la Reconquista y atribuía su fundación a Alfonso I.

Los resultados del estudio realizado a partir de los materiales de los yacimientos de Cangas de Onís ponen de relieve la importancia de realizar estudios de detalle en zonas geográficas concretas, con especial atención al medio físico, y el recurso a la arqueometría para ir elaborando unas tablas de referencia basadas en criterios estratigráficos, radiométricos y mineralógicos que permitan definir y caracterizar con precisión las producciones cerámicas e inferir secuencias sincrónicas y diacrónicas.

\section{BIBLIOGRAFÍA}

AGuAROD, C. (1991): Cerámica romana importada de cocina en la Tarraconense, Zaragoza.

ALARÇAO, J. DE (1975): «La cerámique commune locale et régionale», Fouilles de Conimbriga V. París. AlARÇAO, J. DE y EtIENNE, R. (1976) : «Cerámiques diverses et verres», Fouilles de Conimbriga VI, París. AldecoA, E. (1987): Cerámica tradicional de Faro, Consejería de Industria y Comercio. Principado de Asturias. Oviedo.

AldecoA, E. y Arias, J. (1995): Faro. Mil años de Historia. CAMCO. Centro de Arte Moderno Ciudad de Oviedo. Oviedo

Alonso, M., Sarabia, P. y Bohigas, R. (1987): «La cerámica de El Torrejón de Las Henestrosas, Valdeolea (Cantabria)», I/ Congreso de Arqueología Medieval, Madrid, Vol. V, pp. 445-458.

Álvarez Estrada, F. y Moure, J. A. (1986): «Torres de vigilancia en la costa oriental asturiana», I Congreso de Arqueología Medieval, Huesca 1985, Vol. V, pp.111-122.

ArgüEllo, J. y SuÁReZ SARo, A. (1992): “Conjunto cerámico medieval de San Salvador de Valdedios», III Congreso de Arqueología Medieval, Oviedo 1989, Vol. II, pp. 219-226.

ARnold, D. E. (1985): Ceramic theory and cultural process, New Studies in Archaeology. Cambrigde University Press.

AvILÉs, T. de (1956): Armas y Linajes de Asturias y Antigüedades del Principado (1590). Ed. Oviedo.

BAlfet, H., FAuvet, M. F. y Monzón, S. (1989): Lexique et typologie des poteries, Editions du CNRS, Paris.

BARBERO, A. y VigiL, M. (1984): Sobre los orígenes sociales de la Reconquista, Ed. Ariel. Barcelona.

Bellmunt, O. y Canella, F. (1897): Asturias, Vol. II., Ed. Oviedo.

BlANCO, M., SÁNCHEZ, I. y AsPeRILlA, H. R. (1996): Ensayos de cocción de muestras de arcillas (Inédito).

BoHigas, R. (1986): Los yacimientos Arqueológicos Altomedievales del Sector Central de los Montes Cantábricos, Santander.

Bohigas, R. y G. ${ }^{\circ}$ CAmino, I. (1987): «Las cerámicas medievales del N y NO de la P.I. Rasgos comunes y diferencias regionales», IV Congreso de Cerámica Medieval del Mediterráneo Occidental, Lisboa, pp. 122-124.

Bohigas, R. y SARABIA, P. (1987): «El Castillo de Camargo y los castros altomedievales de Cantabria», II Congreso de Arqueología Medieval, Madrid, Vol. III, pp. 313-325.

BoHIGAS, R. y RuIz, A. (1989): «Las cerámicas visigodas de poblado en Cantabria y Palencia», Boletín de Arqueología Medieval, n. ${ }^{\circ}$ 3, Madrid, pp. 31-51.

Bohigas, R., Andrio, J., PeÑIL, J. y Alonso, M. (1989): «Las cerámicas medievales no esmaltadas en las provincias de Cantabria, Palencia y Burgos», La cerámica medieval en el N y NO de la Península Ibérica, Universidad de León, pp. 113-153. 
Bolado Rebolledo, J. (1987): Los últimos alfares de Cantabria, Diputación Regional de Cantabria. Consejería de Turismo, transporte, Comunicaciones e Industria de Cantabria.

Brime, C. (1999): Caracterización mineralógica de muestras cerámicas, Departamento de Geología, Universidad de Oviedo 1999 (inédito).

CABAL, S. y VilLAmIL, G. (1891): «Excursión escolar universitaria a Faro. 20 de Febrero de 1891», Estudio sobre las pequeñas industrias asturianas, Luarca.

CABAlLERO, L. (1985): «Hallazgo de un conjunto tardorromano en la calle Sur de Getafe (Madrid)», Boletín del Museo Arqueológico Nacional, T. III, n. ${ }^{1}$, pp. 97-127.

Calvo Gálvez, M.(1992): «Experimentando con la arcilla y el fuego como en la Antigüedad». Tecnología de la cocción de la cerámica desde la Antigüedad a nuestros días. Asociación de Ceramología, Alicante, pp.41-50.

Camino Mayor, J. y Viniegra Pacheco, Y. (1996): «El horizonte cronológico y cultural de la Edad del Hierro en Asturias. El caso de la ría de Villaviciosa», II Congreso Peninsular de Arqueología, Zamora.

CAMPS, G. (1980): Manuel de recherche préhistorique, Ed. Doin, París.

Canella y Secades, F. (1871): Resumen de las Actas y Tareas de la Comisión de Monumentos Históricos y Artísticos de la Provincia de Oviedo desde el 11 de Febrero de 1868 hasta la fecha (1871). Apéndice 4.

Canella y Secades, F. (1872): Resumen de las Actas y Tareas de la Comisión de Monumentos Históricos y Artísticos de la Provincia de Oviedo desde 1848 hasta 1866.

Cerrillo, E. (1976): «Cerámicas estampilladas de Salvatierra de Tormes (Salamanca). Contribución al estudio de las cerámicas tardorromanas del valle del Duero», Zephyrus XXXVII-XXXVIII, Salamanca, pp.457-466.

ChAO, F. J., Busto, M. y FAO, M. (1992): «Estudio de los materiales cerámicos de la Peña Castillo (Villaviciosa)», III Congreso de Arqueología Medieval, T. II, Oviedo 1989, pp.200-206.

Diego Somoano, C. (1960): «La Colección Soto Cortés de Labra, Cangas de Onís», Boletín del Instituto de Estudios Asturianos, XL, Oviedo, pp.288-290.

Diego Santos, F. (1985): Epigrafía Romana de Asturias, Instituto de Estudios Asturianos, Oviedo.

DiEgo SANTOS (1994): Inscripciones medievales en Asturias, Consejería de Educación, Cultura y Deportes del Principado de Asturias, Oviedo.

ECHALIER, J. C. (1984): Eléments de technologie céramique et d'analyse des terres cuites archéologiques, Documents d'Archéologie Méridional. Méthodes et Techniques 3. Association pour la Diffusion de l'Archéologie Méridionale. París.

EiroA, J. J., Lomba, J., MartíneZ, C. y Ponce, J. (1989): Apuntes de Tipología Prehistórica, Universidad de Murcia, cap. IV: Tipología Cerámica, pp.105-122.

Encinas MARTíneZ, M. y FeRnÁndez OCHOA, C. (1986): «Precisiones en torno a las cerámicas medievales de la muralla romana de Gijón», I Congreso de Arqueología Medieval, Huesca 1985, Vol. V, pp. 347-361.

Encinas MARTíneZ, M. (1986): «La cerámica medieval en fortalezas y castillos asturianos Peñón de Raíces y Castillo de Tudela)», Boletín del Instituto de Estudios Asturianos, n. ${ }^{\circ} 119$, Oviedo, pp. 307-328.

Encinas MartíneZ, M. (1987): «Cerámicas medievales del monasterio de San Pelayo (Oviedo)», // Congreso de Arqueología Medieval, Madrid 1986, Vol. III., pp.386-392.

Encinas Martínez, M. y García CarRiLlo, A. (1992): «Aportaciones al conocimiento de la transición de mundo romano medieval en Asturias: las cerámicas de Murias de Beloño y Paraxuga», III Congreso de Arqueología Medieval, T. II, Oviedo 1989, pp.131-139.

Estrada, R., García de CAstro, C. y VilLA, A. (1992): «Hallazgo de cerámicas medievales en el concejo de Sariego (Asturias)», III Congreso de Arqueología Medieval, Oviedo 1989, Vol. II, pp. $243-251$.

FEITO, J. M. (1985): Cerámica tradicional Asturiana, Gráficas OGGI, Madrid.

Fernández Buelta, J. M. (1985 reed.): Ruinas del Oviedo Primitivo, Instituto de Estudios Asturianos. Oviedo, 1948.

FERnÁNDEZ CONDE, J. (1989): «Secuencias de la producción de la cerámica en Asturias durante la Edad Media», La cerámica medieval en el N y NO de la Península Ibérica, Universidad de León, pp. 173-210.

Fernández ChItI, J. (1980): Curso Práctico de Cerámica. Vol. I, II y III, Ed. Condorhuasi, 30 Buenos Aires.

FERnÁndez OchoA, C. (1982): Asturias en la época romana, Monografías Arqueológicas, n. ${ }^{\circ}$ 1. Dpto. Prehistoria y Arqueología. Universidad Autónoma de Madrid.

FERNÁNDEZ OCHOA, C. et alii (1992): «Gijón en el periodo tardoantiguo: las cerámicas importadas de las excavaciones de Cimadevilla», Archivo Español de Arqueología, 65, Madrid.

FERnÁNDEZ OCHOA, C. (1994): Una industria de salazones de época romana en la Plaza del Marqués. Ayuntamiento de Gijón.

FERNÁNDEZ OCHOA, C. y ZARZALEJOS, M. (1997): «El registro arqueológico II. Estudio de materiales», en FERNÁNDEZ OCHOA, C.: La muralla romana de Gijón (Asturias), Ayuntamiento de Gijón. 
Gabinete Arqueológico: G. Adán, C. Cabo, R. Estrada, A. Martínez, O. Requejo y A. Villa: Informe sobre los trabajos de Seguimiento Arqueológico en la variante de Corao, Cangas de Onís (Principado de Asturias), Consejería de Obras Públicas del Principado, 1988 (Inédito).

García de CASTRo, C. (1995): Arqueología cristiana de la Alta Edad Media en Asturias, Real Instituto de Estudios Asturianos, Oviedo.

García Guinea, M. A. (1979): El Románico en Santander, Santander.

García Guinea, M. A., GonzÁlez, J. y Madariaga, B. (1963): El Castellar (Villajimena, Palencia), Excavaciones Arqueológicas en España n. ${ }^{\circ} 22$, Madrid.

García Guinea, M. A., González Echegaray, J. y Sanmiguel, J. A. (1966): Excavaciones en Monte Cildá, Olleros de Pisuerga (Palencia), Excavaciones Arqueológicas en España n. ${ }^{\circ} 61$, Madrid.

García Guinea, M. A., Iglesias, J. M. y Caloca, P. (1973): Excavaciones en Monte Cildá, Olleros de Pisuerga (Palencia), Excavaciones Arqueológicas en España n. ${ }^{\circ} 82$.

GonZÁLEZ Y FDEZ.-VALLÉS, J. M. (1966): «Catalogación de los castros asturianos», Archivum, T. XVI, Oviedo, pp.252-291.

GonzÁleZ, J. M. (1976): «Vestigios de siete castillos medievales en Asturias», Miscelánea Histórica Asturiana, Oviedo, pp. 336-339.

GutiéRREZ, J. A. y Beneitez, C. (1989): «La cerámica medieval en León», La cerámica medieval en el N y NO de la Península Ibérica, Universidad de León, pp. 211-260.

GutiérRez, J. A. (2003): Peñaferruz (Gijón). El Castillo de Curiel y su territorio, Ayuntamiento de Gijón, pp. 196-197, 205-207.

HALD, P. (1977): Técnica de la cerámica, Ed. Omega S.A. Barcelona.

IMINSA (1987): Aplicación de materias primas minerales a nuevas tecnologías, Consejería de Industria, Comercio y Turismo. Principado de Asturias (inédito).

Jovellanos, G. M. de (1954 ed.): Diarios, tomo I. Ed. Julio Somoza. Oviedo.

Krauser \& Plaul \& Zöllner (1973): Principes de technique de cuisson et de construction de fours céramiques. Ed. Septima, París.

ManzanaRes Rodríguez, J. (1955): La Iglesia románica de San Pedro de Villanueva. Oviedo, 1955.

MAÑANES, T. (1980): «Las cerámicas tardorromana-visigoda anaranjada y gris con decoración estampada en España noroccidental», Studia Archaeologica, n. ${ }^{\circ} 65$. Valladolid, pp. 215-250.

Martínez Villa, A. (1986): Carta Arqueológica de Cangas de Onís y Onís. Universidad de Oviedo (Inédito)

MARTíneZ, A. y REQUEJO, O.: (1986): «Aproximación cronológica de una serie de hallazgos cerámicos medievales en Asturias», I Congreso de Arqueología Medieval, Huesca 1985 pp. 333-345.

Martínez, A. y Requejo, O. (1995): «1. a Fase de Excavaciones Arqueológicas en el Monasterio de San Pedro de Villanueva, Cangas de Onís, Asturias)», Excavaciones Arqueológicas en Asturias n. 3 (1991-1994), Consejería de Educación, Cultura y Deportes. Principado de Asturias, p. 298.

Martínez Salcedo, A.: «Apunte para el estudio de las cerámicas comunes no torneadas de época romana en el País Vasco Peninsular: el caso de las ollas peinadas de borde de borde vuelto plano», KOBIE, Serie Paleoantropología. Diputación Foral de Bizkaia. Bilbao n. ${ }^{\circ}$ XXV, 1998-1999, pp. 161-182.

Matesanz Vera, P. (1987): «La Cerámica Medieval Cristiana en el Norte (siglos IX-XIII): nuevos datos para su estudio», Il Congreso de Arqueología Medieval, Madrid, Vol. I Ponencias, pp.245-269.

MatThys, A. (1973): «La Céramique», Typologie des sources du Moyen Age Occidental. Fasc. 7. Université Catholique de Louvain.

MAYA, J. L. (1977): «Precisiones cronológicas en torno a las Termas de Campo Valdés, Gijón (Asturias)», B.I.D.E.A., n. ${ }^{\circ} 92$, Oviedo, pp.823-834.

MAyet, F. (1984): Les Céramiques Sigillées Hispaniques, Vol. I y II. Publication du Centre Pierre Paris, 12. París.

Monte Carreño, V. (1980): Cincuenta años de Alfarería Popular en Gijón, Los «Tarreros» de Gijón. Gijón.

Morales, A. de (1791): Crónica General de España. Ed. Acalá 1574,

OlÁvARRI, E. (1970): Memoria de la excavación realizada en la Plaza de la Corrada del Obispo y en el tránsito de Santa Bárbara de la ciudad de Oviedo, Informe preliminar (inédito).

Olmo Enciso, L. (1984): «Excavaciones arqueológicas en Veranes», Gijón Romano, Madrid, pp. 91-93.

Orton, C., Tyers, P. y Vince, A. (1993): Pottery in archaeology. Cambridge University Press.

PAstor Moreno, A. (1992): «La cocción de los materiales cerámicos», Tecnología de la cocción de la cerámica desde la Antigüedad a nuestros días. Asociación de Ceramología. Alicante, pp. 21-38.

PeÑIL, J., BohIgAS, R. y Jimeno, R. (1986): «La cerámica en la región cántabra desde el inicio de la Repoblación hasta la aparición del vidriado», Actas del II Coloquio de Cerámica Medieval del Mediterráneo Occidental, Toledo 1981, pp. 227-232.

Pıcón, M. (1973): Introduction à l'étude technique des céramiques sigillées de Lezoux. Publication du Centre de Recherches sur les techniques Gréco-Romaines n. 2 . Paris. 
PIcón, M. (1984): «Recherches sur les compositions des sigillées hispaniques. Techniques de fabrication et groupes de production», en MAYET, F.(1984): Les Céramiques Sigillées Hispaniques I, Appendice II. Publication du Centre Pierre Paris 12. París.

Requejo, O., Martínez, A. y JimÉnez, M. (1990): «Excavaciones Arqueológicas en el Conjunto Monumental de Valdedios (Villaviciosa) 1988-1989 ", Excavaciones Arqueológicas en Asturias n. 2 (19871990), Consejería de Educación, Cultura y Deportes, Principado de Asturias, pp.179-188.

Requejo PAgés, O. (1990): Estudio de los materiales cerámicos de la Vega de Corao (Cangas de Onís, Principado de Asturias (Inédito).

Requejo PAgés, O. (1992): «Cerámicas tardorromanas de la villa de Murias de Paraxuga (Oviedo)», III Congreso de Arqueología Medieval, Oviedo 1989, pp.140-146.

REQUeJo PAgÉs, O. (1995): «ll Fase de restauración en la iglesia de San Vicente de Serrapio, Aller (19911992): Resultados Arqueológicos», E.A.A., // 1991-94. Oviedo, pp.1293-296.

REQUEJO, O.(1998): «Materiales cerámicos procedentes de San Salvador de Valdedios», Boletín Anual del Museo Arqueológico de Asturias, n. ${ }^{\circ}$ 2, Oviedo, pp.19-26.

Requejo PAgÉs, O. (1999): «Intervención arqueológica en el Monasterio de San Pedro de Villanueva (Cangas de Onís, Asturias): ¿primer asentamiento de la monarquía asturiana?», Intervención restauradora en la arquitectura asturiana, Románico, Gótico, Renacimiento y Barroco. Universidad de Oviedo, pp. 99-110.

Requejo Pagés, O. (1999): Los Hornos Romanos de Cayés, Llanera. Consejería de Infraestructuras Principado de Asturias (Inédito).

RequeJo PAgÉs, O. (Inédito) Estudio cerámico de los yacimientos de Murias de Beloño y Lugo de Llanera.

REQUeJo PAgÉs, O. (2000): Memoria de las Excavaciones Arqueológicas realizadas en el Monasterio de San Pedro de Villanueva (Cangas de Onís, Principado de Asturias), Secretaría de Turismo, Turespaña. Ministerio de Comercio y Turismo (inédita).

Requejo Pagés, O. et alii (1998): El Reinado de los sentidos. Monasterio de San Pedro de Villanueva. Parador de Cangas de Onís, Ed. Paradores de Turismo S.A. Madrid.

Requejo PAgÉs, O. y JimÉnEZ-SÁnchez, M. (2004): «Reconstrucción histórico-arqueológica de un Monasterio medieval utilizando criterios paleohidrológicos: el ejemplo de San Pedro de Villanueva (Asturias)», Actas de la XI Reunión Nacional de Cuaternario, Oviedo 2003. Germán Flor Ed., pp.287-292.

Ruiz de LA PeÑA, J. I., (1995): La Monarquía Asturiana (718-910). Separata de El Reino de León en la Alta Edad Media. Vol. III. León.

SAZ, J. del: Manuscrito de San Pedro de Villanueva. Real Instituto de Estudios Asturianos, Oviedo.

SEMPERE FERRÁNDIZ, E.(1992): «Catalogación de los hornos de España y Portugal», Tecnología de la cocción de la cerámica desde la Antigüedad a nuestros días, Asociación de Ceramología, Alicante, pp.185-236.

ShaW, K. (1974): Ciencia para ceramistas y esmaltadores, Cuadernos del Seminario de Estudios Cerámicos de Sargadelos, n. ${ }^{\circ} 16$. Ed. del Castro.

Sheppard, A. O. (1954): Ceramics for the Archaeologist, Carnegie Institution of Washington. Washington DC. Publication 609. 1985 reprinted.

SinOPOLI, C. M. (1991): Approaches to Archaeological Ceramics, Plenum Press.New York and London.

THIRIOT, J. (1979) : «Notes sur les origines de la vaiselle des cuisines avignonnaises au Royev Age», Revue Annualle d'information, Maine d'Avignon.

THIRIOT, J. (1986): «Les ateliers médievaux de poterie grise.En Uzège et dans le Bas-Rhône. Premières recherches de terrain", Documents d'Archéologie Française, n. ${ }^{\circ}$ 7. Editions de la Maison des Sciences de l'Homme, París.

Tranoy, A. (1981): La Galice Romaine. Recherches sur le nord-ouest de la Peninsule Iberique dans I'Antiquité, Publications du Centre Pierre Paris (ERA 522), Collection de la Maison des Pays Ibériques. G.I.S. 15 Paris.

VeGAS, M. (1973): Cerámica común romana del Mediterráneo Occidental, Instituto de Arqueología y Prehistoria. Barcelona.

VV.AA. (1989): La Cerámica Medieval en el Norte y Noroeste de la Península Ibérica. Aproximación a su estudio, Universidad de León.

VV.AA (1993): Tabula imperii Romani, Hoja K-30: Madrid. Caesaraugusta, Clunia. Instituto Geográfico Nacional. 
El Registro Arqueológico en el territorio de Cangas de Onís (Principado de Asturias)...

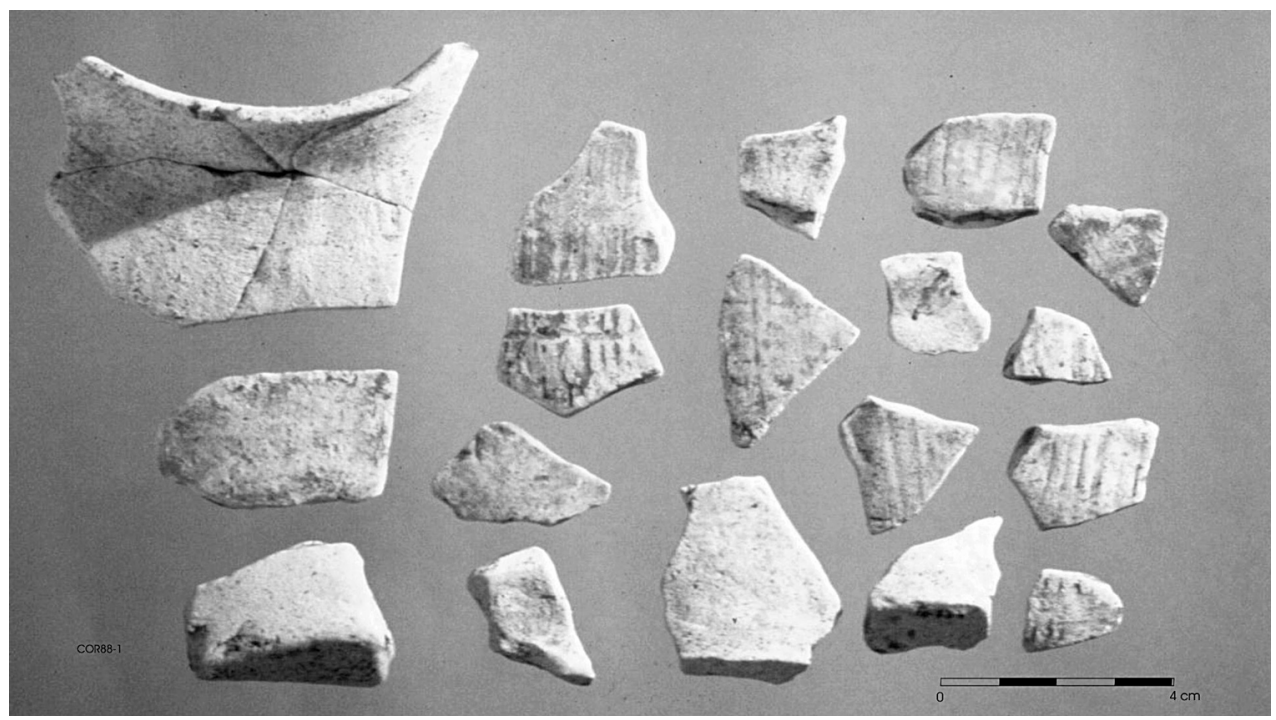

Lámina I. Cerámicas incisas de la finca de San Nicolás, Vega de Corao. 


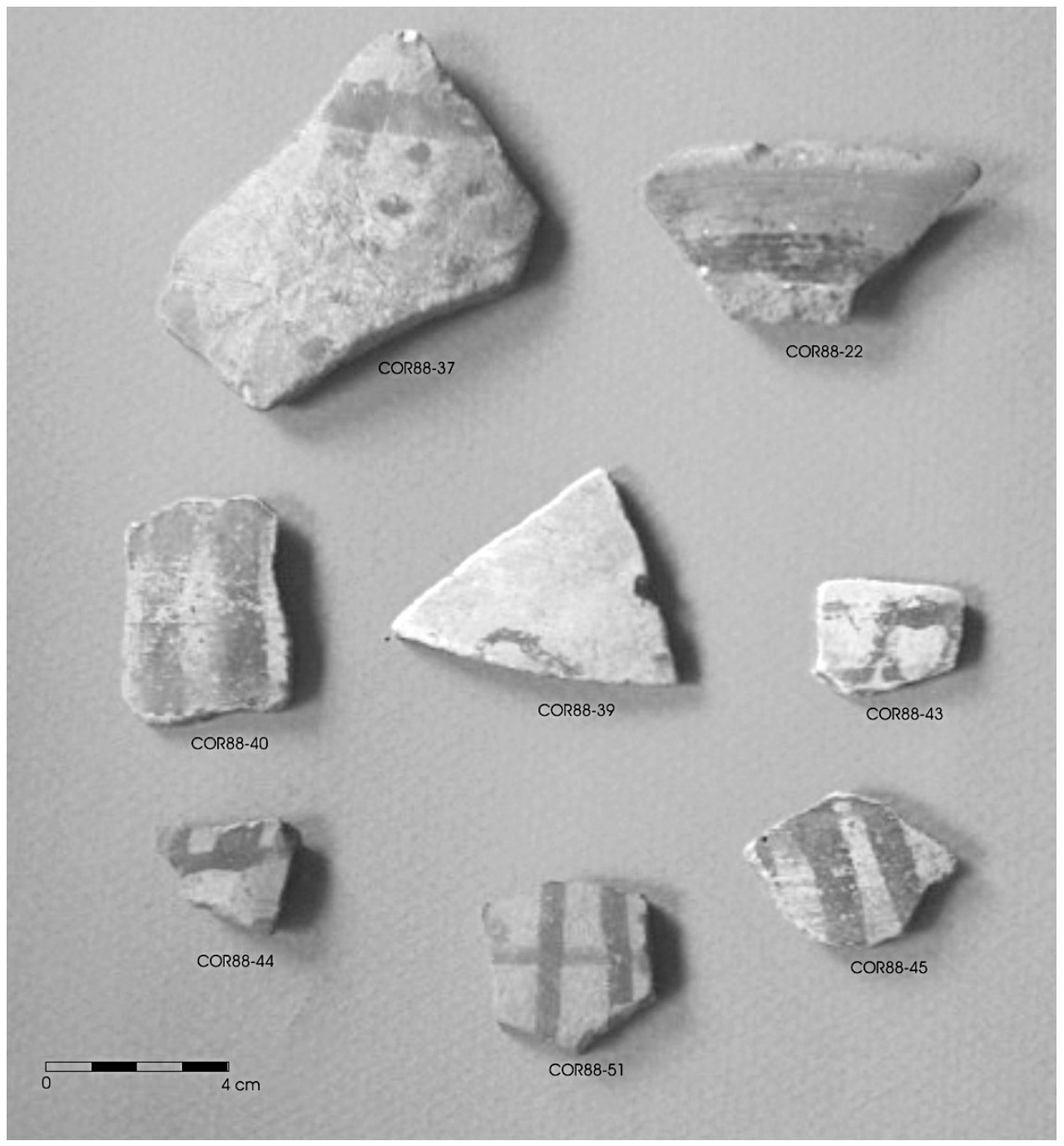

Lámina II. Cerámicas pintadas de la finca de San Nicolás, Vega de Corao. 
El Registro Arqueológico en el territorio de Cangas de Onís (Principado de Asturias)...
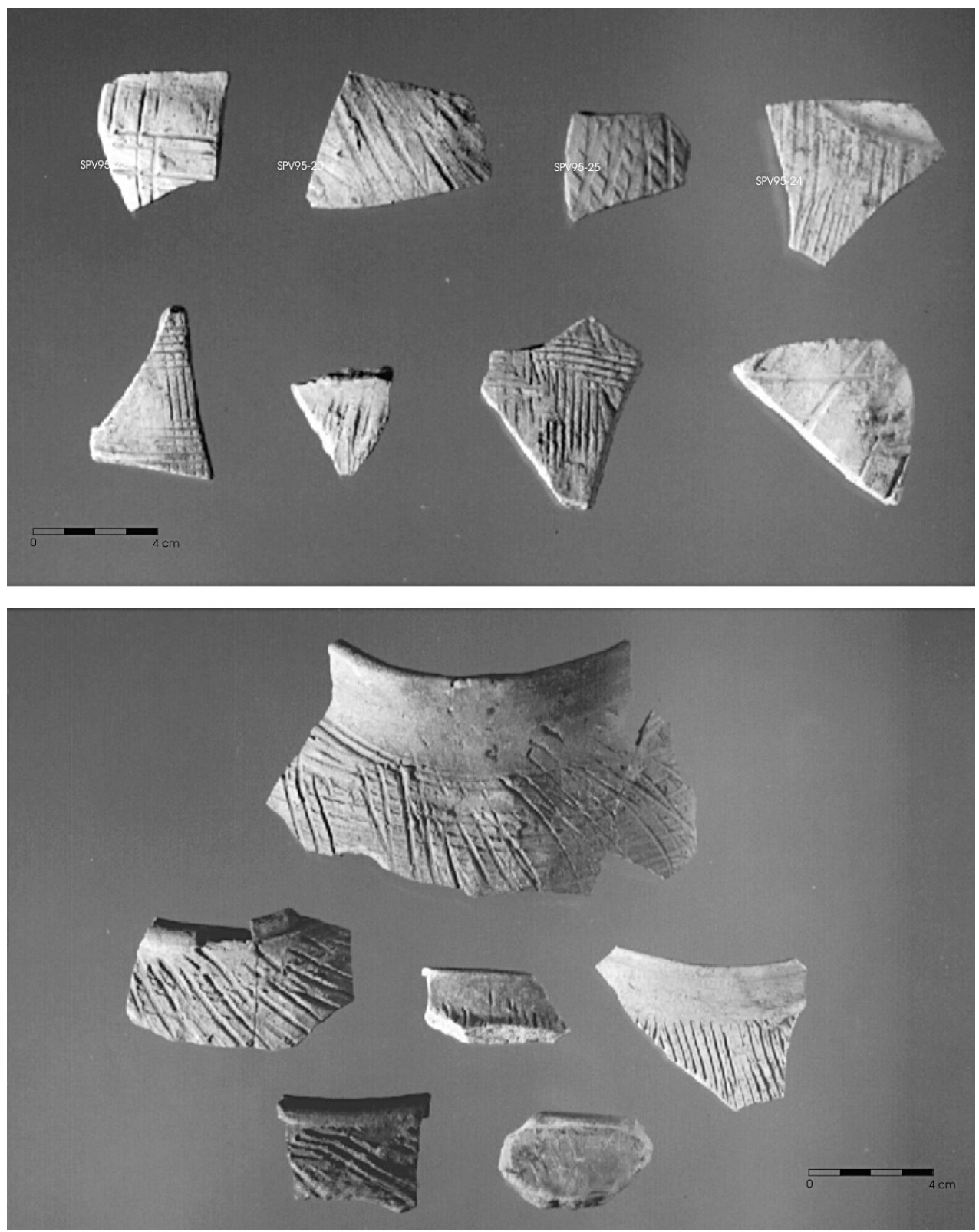

Lámina III. Cerámicas incisas de San Pedro de Villanueva. 


\section{O. REQUEJO PAGÉS}
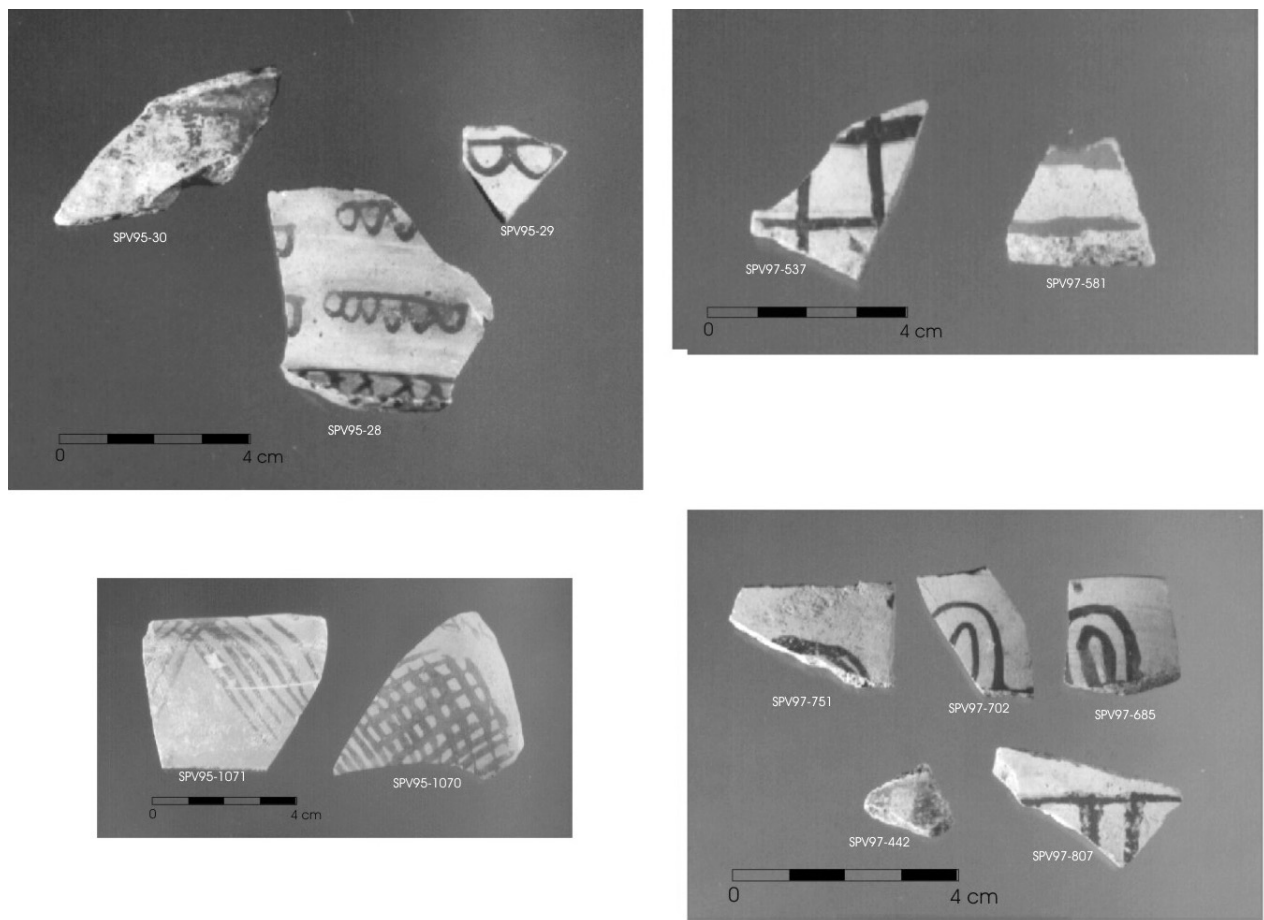

Lámina IV. Cerámicas pintadas de San Pedro de Villanueva.

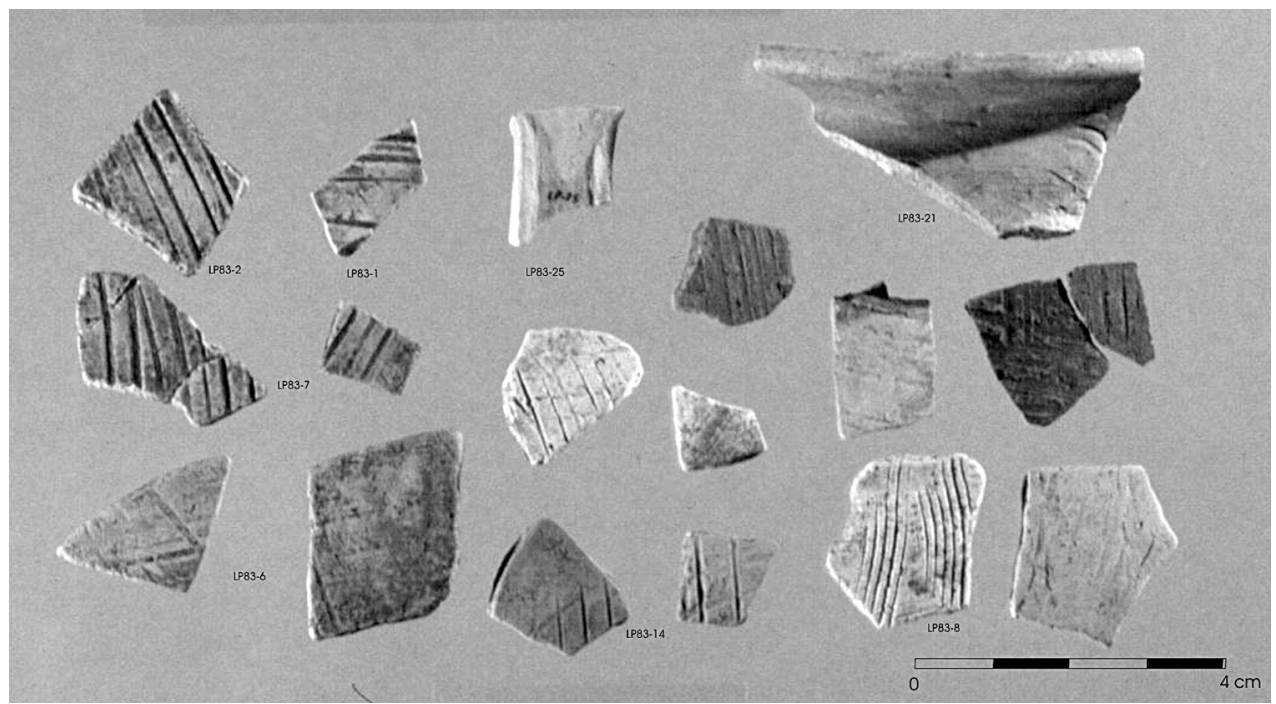

Lámina V. Cerámicas incisas y estriadas de la Fortaleza de la Porra. 


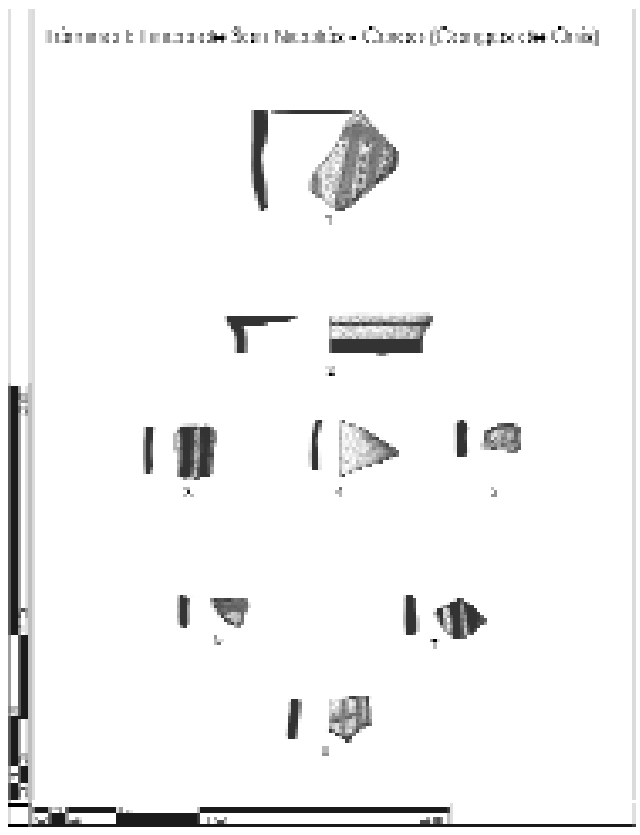

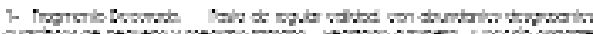

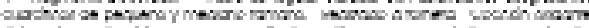

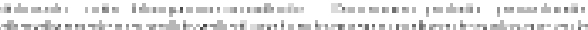

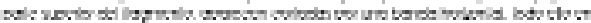
onomeinstas ich

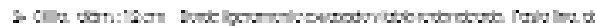

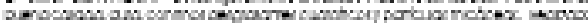

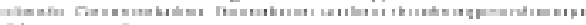

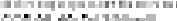

cotedosures

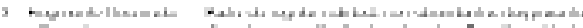

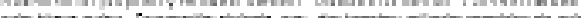

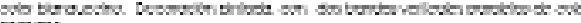
toga:

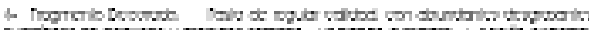

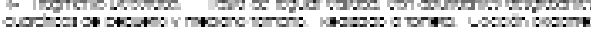

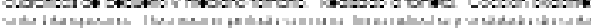
arsinglats

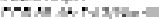

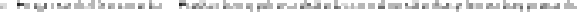

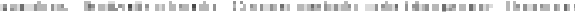

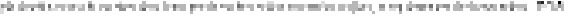
wowetrutave

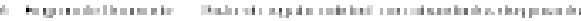

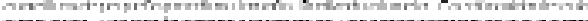

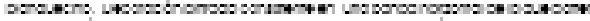

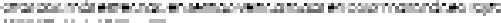

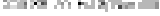

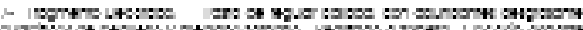

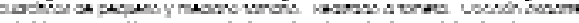

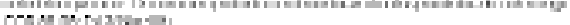

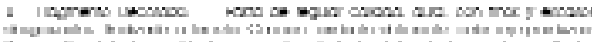

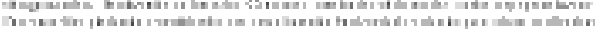

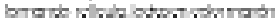

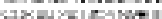

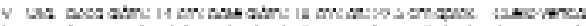

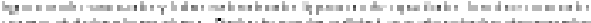

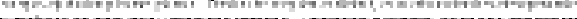

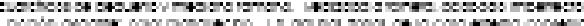

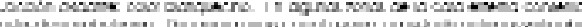

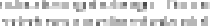

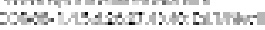

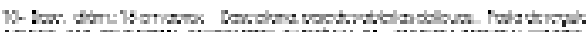

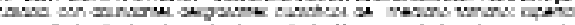
cove mitaven

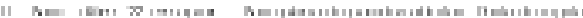

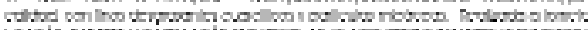

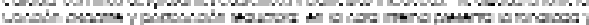

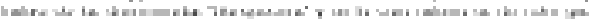
octoris:

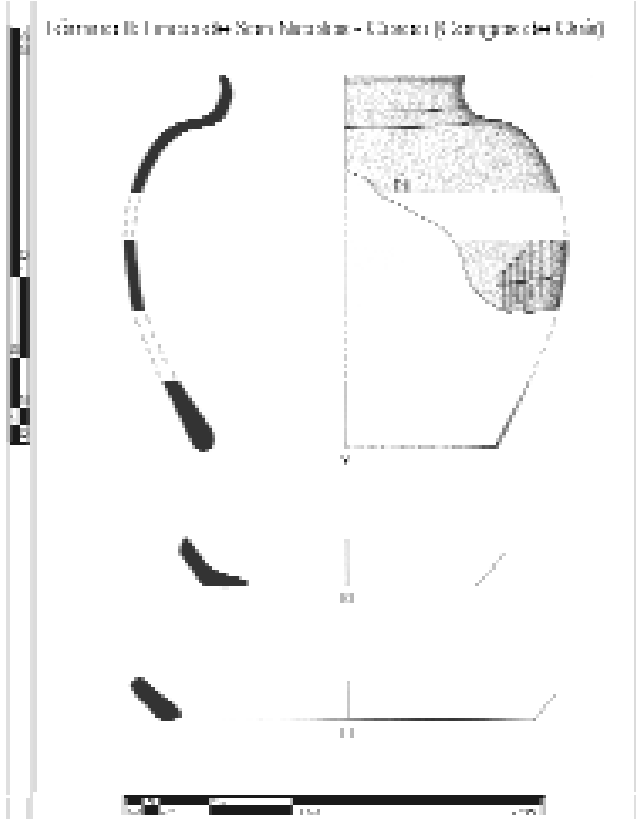




\section{O. REQUEJO PAGÉS}

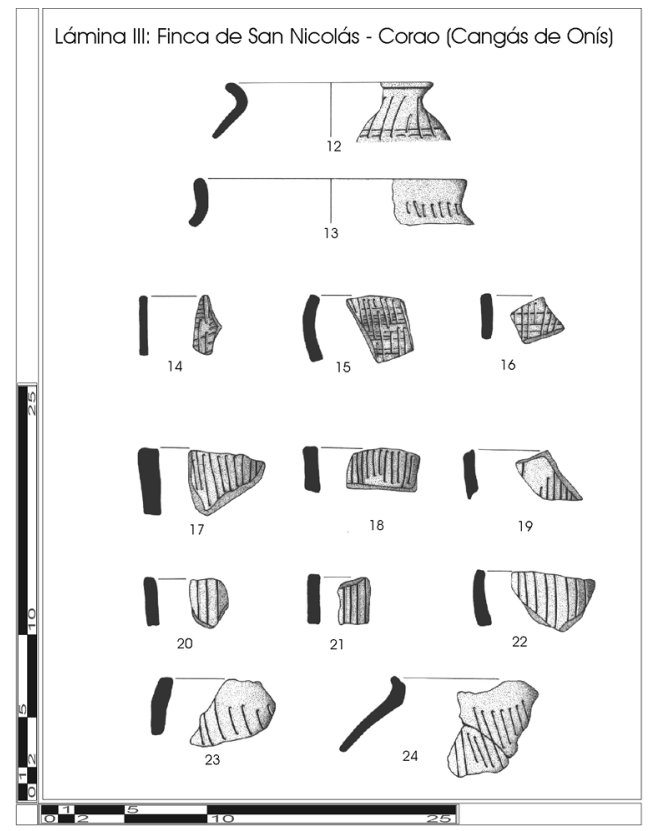

12- Olla. dím: $12 \mathrm{~cm}$ Borde exvasado, lablo redondeado y arranque de cuerpo globular. Pasta de buena calidad, dura y de sonido metálico, con finos desgrasantes cuarćticos. Realizada a tometa, acabado imperfecto, $\circledast$ observa la huella de la espátula en la cara interna. Cocción reductora; color gris. Decoración incisa consistente en línecis verticales que arrancan del borde y son contadas por otras horizontales en el cuerpo. COR-88-80: Est.3/ NivelIV

13- Olla. diám.: $16 \mathrm{~cm}$ Borde vertical y labio redondeado, con arranque de cuerpo globular. Pasta de regular calidad, dura y de sonido metálico, con desgrasantes cuarćíticos de mediano tamaño. Realizada a torneta. Cocción reductora: color gris Decoración incisa, en el cuello, consistente en líneas verticales, toscamente trazodas con

COR-88-75: Est. 7/ Nive| III

14- Fragmento Decorado. Pasta de buena calidad, dura, con finos desgrasantes cuarcíticos. Realizado a torno. Cocción reductora y postcocción oxidante:: color gris en el interiory anaranjado en el exenor. Decoracion incisa consistente en rrazos discontinuos

COR-88-10: Est.1/Nivellil

15- Fragmento Decorado. Pasta de buena callidad, duray de sonido metálico, con finos desgrasantes cuarćticos. Realizado a tomo Cocción reductora color gris Decoración inclsa consistente en trazos discontinuos verticales y horizontales, bien marcados, que se

entrecruzan formando refícula.
COR-88-26: Est.2/NivelIII

16- Fragmento Decorcado. Pasta de buena calidad, duray de sonido metálico, con finos desgrasantes cuarcíticos. Realizado a torno, Cocción reductora: color gris Decoración incisa consistente en trazos discontinuos verticales y horizontales que se entrecruzan formando retículo.

COR-88-30: Est.3/ NivellI

17. Fragmento Decorado. Pasta de regular calidad, dura, con groseros desgrasantes cuarcíticos. Realizado a torneta. Cocción oxidante postcocción reauctora. color anaranjado en la cara internay gisclaro en la cara exiema. Decoración incisa consist trazadas con peine. 18- Fragmento Decorado. Pasta de regular callidad, dura y de sonido metálico, con abundantes desgrasantes cuarcíticos de pequeno y mediano tamaño. Reclizado a verticales anchosy toscamente trazados con peine.

COR-88-37: Est.3/Nivelll

19- Fragmento Decorado. Pasta de regular calidad, con desgrasantes cuarcíficos de mediano tamaño, superficie granulosa. Realizado a tometa. Cocción reductora: color gris oscuro. Decoración incisa consistente en estrías verticales, anchas y profundas, trazadas con peine.

COR-88-11: Est. 1/NivellII

20- Fragmento Decorado. Pasta de regular calidad, tosca, granulosa, con abundantes desgrasantes cuarcíticos Realizado a torneta. Cocción reductora: color gris claro Decoraciónincisaconsistente en estrías verticales anchasy profundas.

COR-88-44: Est.3/ NivellII 21- Fragmento Decorado. Pasta de regular calidad, con abundantes desgrasantes
cuarcíticos de pequeño y mediano tamaño y prículas micáceas. Realizado a torneta cuacciticos de pequeno y mediano tamano y priculas micaceas Realizado a torneta la externa. Decoración incisa consistente en estrías verticales, anchas y profundas toscamente trazadas con peine.

toscamente trazadas con
COR-88-38: Est.3/ Nivel III

22- Fragmento Deccrado. Pasta de regular callidad, tosca, con abundantes y groseros descrasantes cuarcíticos. Realizado a tometa. Cocción oxidante, postcocción reductora deficiente: color anaranjado, gris-marión en la cara externa. Decoración incisa consistente en estrias verticales, anchasy profundas, toscamente trazadas con peine. COR-88-32: Est. 3/ Nivel III

23- Fragmento Decorado. Pasta de mala calidad, con abundantes desgrasantes cuarcíticos. Realizado a torneta. Cocción reductora: color gris. Decoración incisa consistente en estrias verticales, ligeramente oblicuas, anchas y profundas, toscamente

trazadas conpene. 24- Olla. diám. indeterminado. Pasta de mala calidad, tosca, dura y de sonido
metálico, con abundantes desgrasantes cuarcíticos. Realizada a torneta. Cocclón reductor con abundantes desgrasantes cuarchlicos. Realzada a tonse. Cocclón verticales, ligeramente oblicuas toscamente trazadas con peine. COR-88-09: Est 1/NivelliI 
25- Borde de Olla diám: $20 \mathrm{~cm}$ Borde verticaly lable redondeado con arranque de asade desarrollo vertical y sección rectangular. Pasta de buena calidad, duray de sonido metálico con finos cescrasantescuarćitios. Realizada a torno. cocción oxdante: color ocre.

COR-88-23: Est.2/ NivellII

26- Borde de Olita diám: $10 \mathrm{~cm}$ Borde vertical y labio recto.. Pasta de buena calidad dura y de sonido metálico, con abundantes y finos desgrasantes cuarcíticos. Realizada torneta. Coccion oxidanie: color amarillo-claro-ocre.

COR-88-35: Est.3/ NivellII

27. Asa. Sección rectangular. Pasta de buena calidad, duray de sonido metálico, con finos y abundantes desgrasantes cuarćlicos. Cocción oxidante: color amarilo claroOCre..

28. Asa. Sección rectangular. Pasta de buena calidad, dura y de sonido metólico, con finos desgrasantes cuarcíticos. Cocción oxidante: color ocre. Decoración consistente en una largaincisión vertical una larga incisión vertical.
COR-88-45: Est.3/ Nivel III

29. Asa. Sección rectangular. Pasta de buena calidad, dura y de sonido metálico, con finos desgrasantes cuarcíticos Cocción oxidante: color ocre Decoración incisa consistente en puntos, trazadoscon punzón.

COR-88-03: Est.1/ Nivellil

30- Fragmento de Olla: cuello y arranque de cuerpo. Pasta fina, de buena callidad con escasosy finos desgrasantes cuarcíticos. Realizado a tomo. Cocción oxidante: color ocre. Decoración incisa, en el arranque del cuerpo, consistente en estrías verticales

trazadas con peine.
COR-88-47: Est.3/ Nivel III

31- Fragmento Decorado, Pasta de regular calidad, duray de sonido metálico, con finos desgrasantes cuarciticos. Realizado a torno. Coccion reductora deficiente: color grismarronáceo. Decoración incisa consistente en estrias verticales y horizontcles, anchas profundas, tiazadasconpent

32. Fragmento decorado. Pasta fina de buena calidad, dura y de sonido metólico, con 32- Fragmento decorado. Pasta fina, de buena calidad, dura y desonido metalico, con
finos desgrasantes cuarcíticos. Realizada a torno. Cocclón oxidante: color amarillento finos deggrasantes cuarciticos Realizada a torno. Cocclon oxidante: color ama.
ocre. Decoración incisa consistente en una linea ondulada bastante marcada. COR-88-70: Est.3/ Nivel III

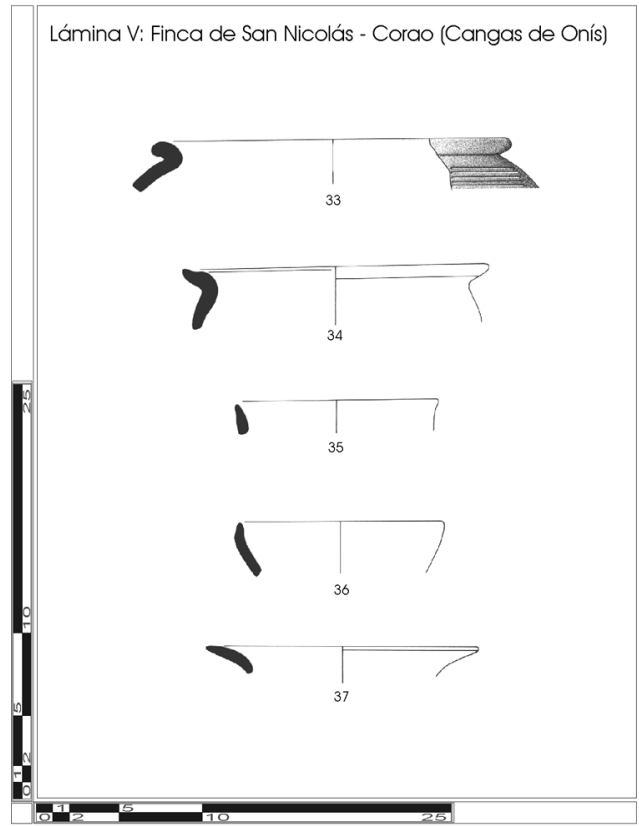

Lámina IV: Finca de San Nicolás - Corao (Cangas de Onís)
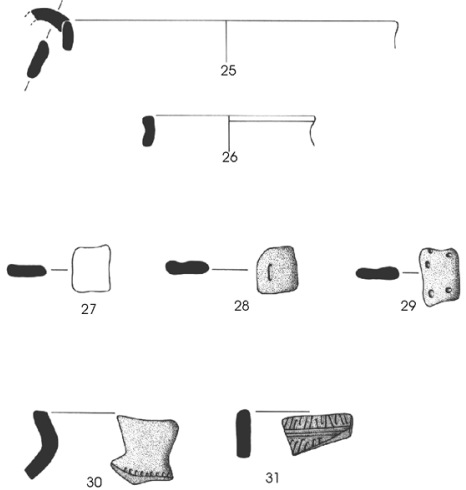

31

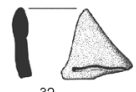

33- Olla diám: $20 \mathrm{~cm}$ Borde exvasado, labio redondeado, sin cuello y cuerpo globular. Pasta de buena calidad, dura, con finos desgrasantes cuarcíticos Realizada a torno. Cocción oxidante: color anaranjado. Decoración incisa, consistente en estría horizontales, estrechas, trazadas con peine. COR-88-66: Est.3/ Nivelll

34- Olla diám: $18 \mathrm{~cm}$ aprox Borde exvasado, ligeramente escalonado y arranque de cuerpo vertical. Pasta de buena calidad, con finos desgrasantes cuarcíticos. Realizada a

tomo. Coccion oxidante: Coloranaranjado.
COR-88-65: Est.3/ Nivelll

35- Olla. diám.: $12 \mathrm{~cm}$ Borde vertical y labio redondeado, ligeramente apuntado Pasta fina, de buena calidad, con escasos y finos desgrasantes cuarcíticos. Realizada a tomo. Cocción oxidante: colornaranie.

COR-88-67: Est.3/ NivellI

36- Cuenco. diám: $12 \mathrm{~cm}$ aprox. Borde envasado, labio redondeado, ligeramente apuntado y cuerpo curvo convexo. Pasta de buena calidad, dura, con escasos y finos desgrasantes cuarciticos. Realizada atorno. Cocción reductora: color gris oscuro.
COR-88-02: Est. 1/ Nivelll

37- Olla. diám: $16 \mathrm{~cm}$ Borde exvasado, y lablo redondeado apuntado. Pasta de buena calidad, dura y de sonido metalico, con abundantes desgrasantes cuorcíticos de pequeño y mediano tamaño. Realizada a torno; acabado imperfecto. Cocción reductora: Colorgris oscun 


\section{O. REQUEJO PAGÉS}

Lámina Vl: Finca de San Nicolás - Corao (Cangas de Onís)
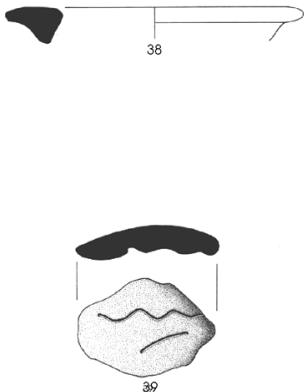

ámina VII Monasterio de San Pedro de Villanueva (Cangas de Onís)
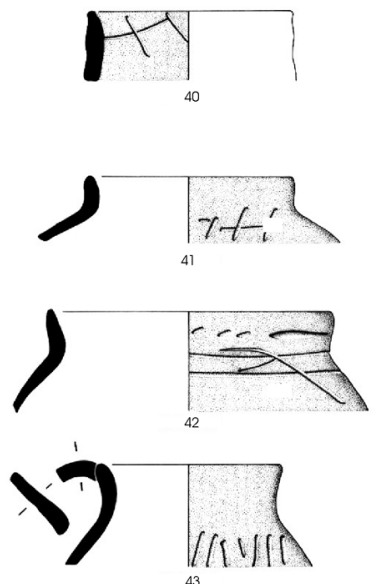

43
38. Olla. diám: $18 \mathrm{~cm}$ Borde exvasado, horizontal y labio redondeado.. Pasta de regular calidad, porosa, borde horizontal plano, con finos y abundantes desgrasantes
cuarćíticos y partículas micáceas. Realzada a tometa. Cocción reductora color grisćcceo.. Recogida superficial. grisáceo.. Re

39- Fragmento de Teja. Pasta de regular calidad, con tinos desgrasantes cuarcíticosy partículas micácéas. Cocción oxidante: color anaranjado. Decoración incisa consistente enuna línea onduladay otra ligeramente curva.

COR-88-81: Cata Y, Nivel llb
40- Olla. diám: $10 \mathrm{~cm}$ Borde recto, labio redondeado y cuello largo, ligerisimamete exvasado. Pasta de calidad regular, con finos desgrasantes cuarcíficos. Realizado a torneta. Cocción reductora: color gris claro en sección y cara interna y negruzco en la cara externa. E el intericr presenta una incisión oblicua cortada por otras dos incisiones en SPV95-V1-8 41- Olla. diám: $10 \mathrm{~cm}$ Borde recto, labio redondeado y cuello recto y arranque de cuerpo con tendencia globular. Pasta de calidad regular, con finos desgrasantes blanquecino en la sección y gris más oscuro en ambas caras Decoración incisa giv arranque de las panza consistente en una estría horizontal cortada por otras verticales aislada

SPV95-V1-15

42- Olla. diám: $14 \mathrm{~cm}$ Borde ligeramente exvasado, labio redondeado, cuello lcortoy arranque de cuerpo curvo. Pasta de bastante buena calidad, dura y de sonido metálico. con escasos desgrasantes cuarcilicos y particulas micaceas. Realzado a tometo cocción reductora deficiente: seccion tipo sandwich, color gris claro-rosado-gris claro Decoración tosca con incisiones en forma de ojal en el cuello y líneas horizontales y curvas enel arranque del cuerpo.

SPV95-IVI-1

43- Jarra. diám: $9 \mathrm{~cm}$ Borde ligeramente exvasado, labio redondeado y cuelo largo, con arranque de cuerpo globular. Asa de cinta de sección triangulary desarrollo curvo que arranca del labio. pasta de callad regular, dula $y$ de sonido melálco, con finos

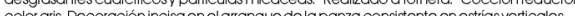
colorgris. Decor
SPV95-V1-9 
Lámina VIII Monasterio de San Pedro de Villanueva (Cangas de Onís)
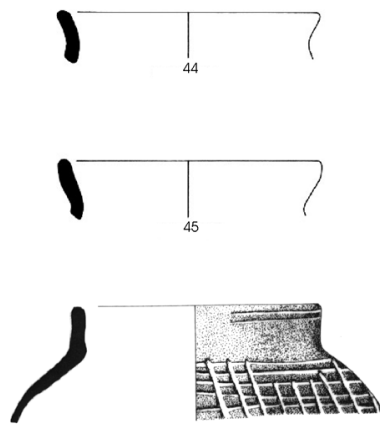

46

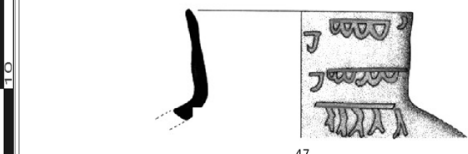

Lámina IX: Monasterio de San Pedro de Villanueva (Cangas de Onís)
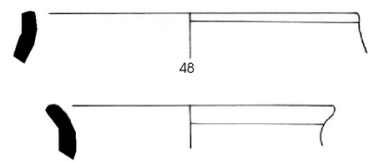

49

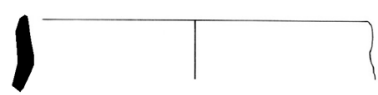

50

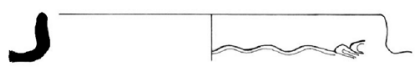

51

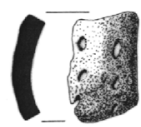

52
44.- Olla. diám: $12 \mathrm{~cm}$. Borde exvasado y lablo redondeado y cuello cóncavo. Pasta de regular calidad, dura, con finos desgrasantes cuarćíticos. Realizada a torneta. Cocción regular reductora: color grisen la sección y gris mivy claro en ambas caras SPV95-111-16

45- Olla aiám: $12 \mathrm{~cm}$. Borde exvasado y labio redondeado y cuello corto. Pasta de regular calidad, dura, con finos desgrasantes cuarcíticos y particulas micáceas. Realizada a tometa. Cocción regular reductora: color gris.

SPV95-111-16

46.- Olla. diám: $11 \mathrm{~cm}$. Borde vertical, labio redondeado y arranque de paredes curvas. Fasta de regular calidad, dura, con abundantes y finos desgrasantes cuarcíticos y partículas micóceas. Realizada a tometa. Cocción reductora: color gris. Decorada con lineas horizontales cortadas por otras verticales, inclinadas a la derecha, toscamente trazadas.
SPV97-667

47.- Jarra. Diám: $12 \mathrm{~cm}$ Cuello vertical, labio ligeramente apuntado y amanque de cuerpo globular. Pasta de regular calidad, dura, con finos desgrasantes cuarciticos y particulas micaceas. Realizada a iometa. cocción recuctora delicente, postcocción oxidante: sección liposanawich. colorbeige-grs-beige. Decoracion pintada en el cuello consistente en dos series horizontales de arcos invertidos y otra banda de motivos lineales verticales en el arranque de la panza de tonalidad marrón rojizo.

SPV95-IV-1-28
48.- Jarra diám: $14 \mathrm{~cm}$ Cuello vertical ligeramente envasado y labio recto. Pasta de reductora postcocción oxidante: color gris en la sección yanaranjado en ambas caras. SPV97-1026

49- Olla diám: $12 \mathrm{~cm}$ Borde exvasado y labio redondeado. Pasta de regular calidad, con finos y abundantes desgrasantes cuarcíticos. Realizada a tometa. Cocción reductora: color gris claro.

SPV97-987

50. Jarra. diám.: $18 \mathrm{~cm}$ Cuello vertical y labio redondeado, ligeramente apuntado. Pasta de regular calidad dura, con finos desgrasantes cuaríticos y parículas micáceas Realizado a torneta. Cocción reductora: colorgris

SPV97-997

51.- Olla. diám: $18 \mathrm{~cm}$ Borde vertical, labio redondeado, hombro marcado y arranque de paredes globulares. Pasta de regular calidad, con finos y abundantes desgrasantes cuarcíticos y micáceos. Realizada a torneta. cocción reauctora: color gris claro. Decorcda con una linec ondulada incisa en el arranque de la panza SPV97-941

52.-Asa. Asa de cinta, de desamollo vertical. Pasta fina, de bastante buena calidad con finos desgr en la seccion y beige-anaranjado en ambas caras. Decorada con motivos incisos en forma de ojal trazadosa punzón.

SPV97-652

53.- Fragmento Decorado. Pasta fina, de bastante buena calidad, dura y de sonido metálico, con finos desgrasantes cuarcíticos. Realizado a torneta. Cocción reductora:

color grisáceo. Decorado con una línea ondulada incisa 


\section{O. REQUEJO PAGÉS}

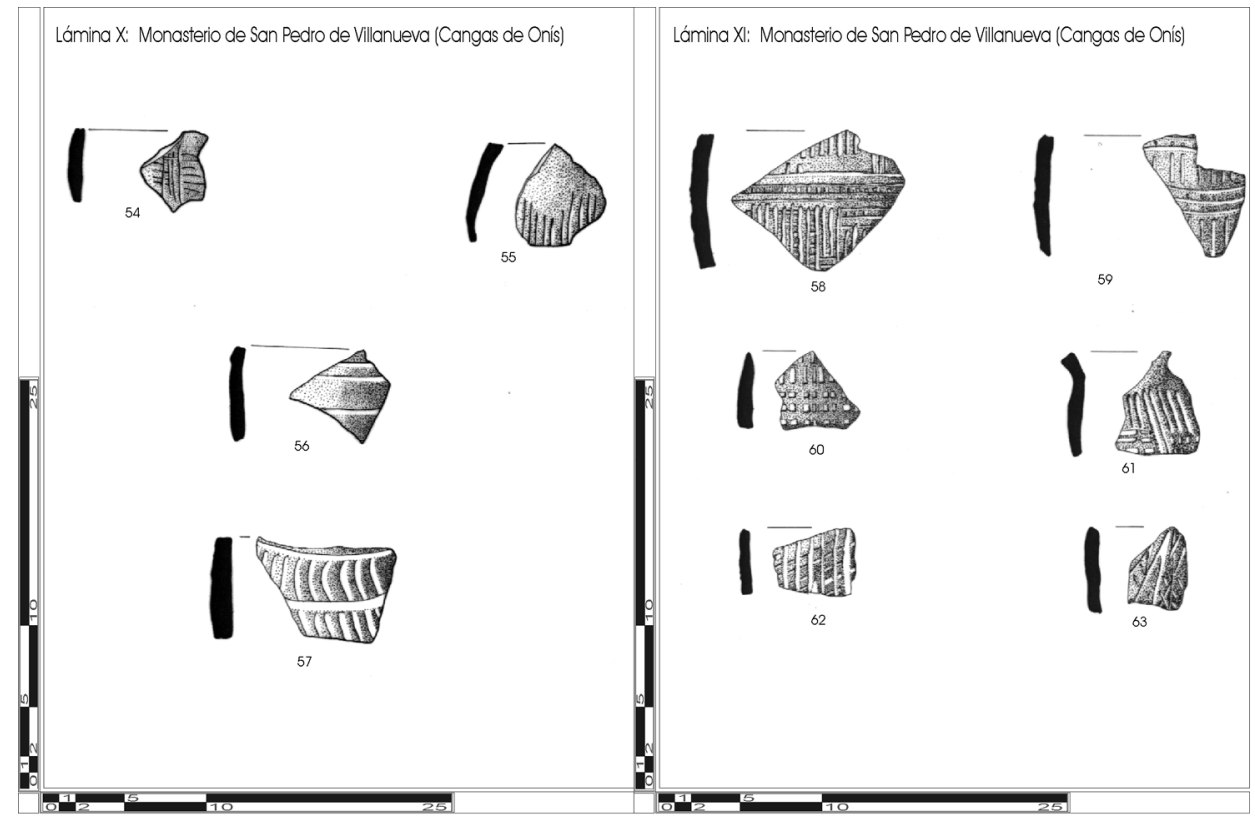

54- Fragmento Decorado. Pasta de bastante buena calidad. Blanda. Escasos y finos
desgrasantes. Cocción oxidante: color beige claro, casi amarillento. Tometa. Cepillado interior. Decorado con lineas horizontales incisas toscamente trozadas, contadas por bandas de líneas verticales

SPV-90-E4-VI-2

55- Fragmento Decorado. Pasta basta, dura y de sonido metálico. Tometa. Acabado defectuoso. Desgrasantes cuarciticos groseros. Cocción regular, reductora: color gris oscuro extericr, violáceo interior. Decorado con líneas incisas verticales anchas y

SPV-90-E4-YYl-1

56- Fragmento Decorado. Pasta fina, de bastante buena calidad, con finos desgrasantes cuarcíticos. Realizado a torneta. Cocción reductora: color gris. Decorado con líneas horizontales incisas.

horizontales
SPV $97-735$

57- Fragmento Decorado. Pasta de regular calidad, duray de sonido metólico, con finos desgrasantes cuarćticos y partículas micáceas. Reallzado a torneta. Cocción reductora deficiente: color gris en la sección y beige-grisáceo en ambas caras. Decorado con lineas verticales incisas cortadas por líneas horizontales aisladas.

SPV $97-393$ 58- Fragmento Decorado. Pasta tina, de bastante buena callidad, dura y de sonido
metálico, con finos desgrasantes cuarcíticos Realizado a torneta. Cocción reductora, postcocción oxidante: color gris en la sección y beige-amarillento en ambas caras. Decorada con líneas verticales incisas cortodas porbandas de líneas horizontales SPV97-870

59- Fragmento Decorado. Pasta de regular calidad, con finos desgrasantes cuarcíticos. Realizado a tometa. Cocción reductora: color gris claro. Decorado con líneas verticales incisas cortadas por bandas de lineas horizontales

SPV97-363

60- Fragmento decorado. Pasta de regular calidad, blanda, con abundantes y finos desgrasantes cuarćticos; superficie rugosa. Realizada a tometa. Cocción reductora: color blanquecino en la sección, gris claro en la cara inienna y glis oscuro en la cara horizontales. SPV97-428

61- Fragmento Decorado. Pasta de regular callidad, dura y de sonido metálico, con finos desgrasantes cuarcíticos y partículas micáceas. Realizado a torneta. Cocción reductora: color gris. Decoración incisa, en el arranque del cuerpo, consistente en líneas verticales, inclinadas a la derecha, cortadas por bandas de líneas hoizontales. SPV97-504

62- Fragmento Decorado. Pasta de regular calidad, con finos desgrasantes cuarcíticos $y$ partículas micaceas. Realizada a torneta. Cocción reductora: color grisclaro en seccióny cara interna y gris algo mas oscuro en la cara exlena. Decorado con lineas oblicuas, PPV $97-769$

63- Fragmento Decorado. Pasta de regular calidad, dura, con finos desgrasantes

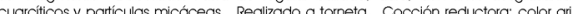
cuarciticos y particulas micáceas. Realizado a torneta. Cocción reductora: color gris entrecruzodas tomando reticula SPV97-513 
Lámina XII Monasterio de San Pedro de Villanueva (Cangas de Onis')

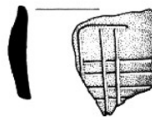

64

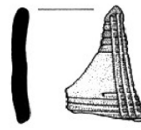

70
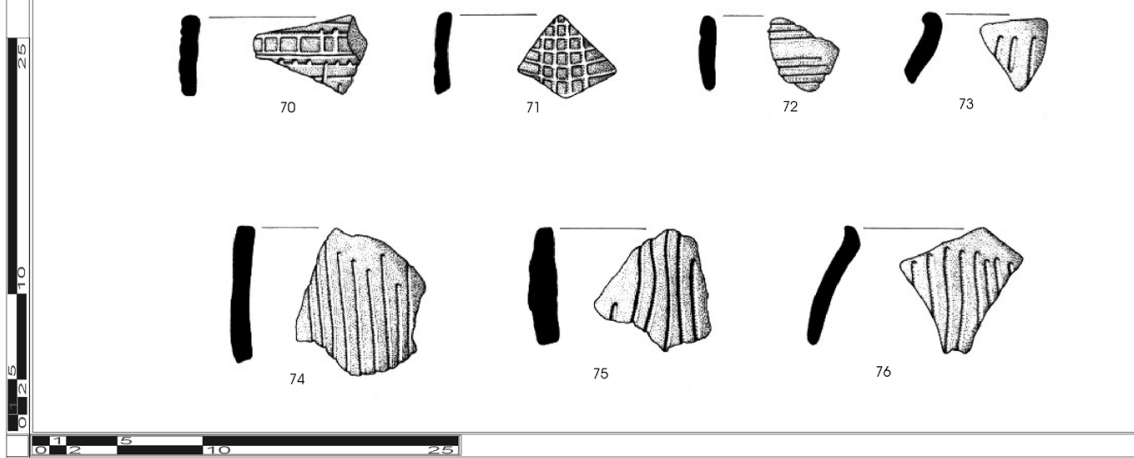
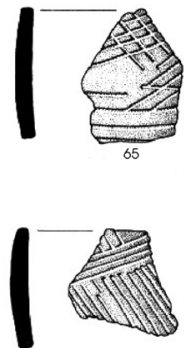

68
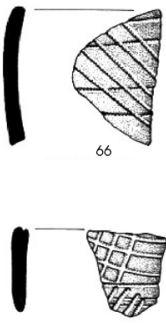

69

64- Fragmento Decorado. Pasta fina de regular calidad, con escasos y finos desgrasantes cuarcíticos. Realizado a tometa. Cocción reductora: color gris-blanquecino. Decorado con líneas incisas horizontales cortadas por líneasverticales. SPV-95-III1-34

65- Fragmento Decorado. Pasta de calidad regular, dura, con finos desgrasantes cuarcíticos. Realizada a torneta. Cocción reductora: color gris-blanquecino en la car interna y seccion y mas oscuro en la cara externa. Decorcdo con linec SPV-95- $-1 \mid 1-33$

66- Fragmento Decorado. Pasta de regular calidad, duray de sonido metálico, con finos desgrasantes cuarcíticos Realizado a tometa. Cocción reductora: color grisblanquecino. Decorado con líneas horizontales incisas cortadas por líneas incisas oblicuas formandoreticula.

SPV-95-117-24

67- Fragmento Decorado. Pasta de regular calidad, dura y de sonido metálico, con finos desgrasantes cuarcíticos; superficie rugosa. Realzado a tometa. Cocción reductora: color gris. Decorado con bandas de finas líneas horizontales incisas cortadas por líneas verticales

SPV-95-111-22

68- Fragmento Decorado. Pasta de regular calidad, dura, con finos desgrasantes cuarcíticos. Realizado a tometa. Cocción reductora: color gris-blanquecino en la sección y gris en ambas caras. Decorado con finas lineas oblicuas incisas cortadas por bandas de líneashorizontales.

SPV-95-111-25

69- Fragmento Decorado. Pasta de regular calidad, con finos desgrasantes cuarcíticos Realizado a tometa. Coccionfoxidante, postcocción reductora: : color gris en la sección y cara externa y rosáceo en la cara interna. Decorado con líneas horizontales incisas cortadas líneas verticales oblicuas formando refícula

SPV-95-117-3

70- Fragmento decorado. Pasta de bastante buena calidad, con abundantes y fino desgrasantes cuarciticos y particulas micaceas. Realizado a torneta. Cocción reductora deficiente: color gris-beige en sección y beige en ambas caras. Decorado con líneas incisas verticales cortadas por líneas horizontales formando reticula. SPV-95-IVI-7

71- Fragmento decorado, Pasta de bastante buena callidad, con abundantes y finos desgrasantes cuarcíticos y parfículas micáceas. Realizado a torneta. Cocción reductora deficiente: color gris-beige en seccion y beige en ambas caras. Decorado con líneas 72- Fragmento Decorado. Pasta de regular calidad, dura, con abundantes y finos
desgrasantes cuarcíticos; superficie rugosa. Realizada a torneta. Cocción reductora: desgrasantes cuarciticos; superficie rugosa. Realizada a torneta. Cocción reductora: Decorado con finas líneas horizontalesincisas. Decorado con
SPV95- $111-27$

73- Fragmento Decorado. Pasta de regular calidad, dura, con finos desgrasantes carcíticos. Realizado a tometa. Cocción reductora: color gris-blanquecino. Decorado conlíneas verticales incisas.

SPV95-111-20

74- Fragmento Decorado. Pasta de regular calidad, dura, con abundantes desgrasantes cuarciticos; superficie rugosa.. Realizado a tometa. Cocción deficiente, oxidante con postcocción reductora: color ris anaranjado onla sección anaraniado en la cara interna y grisoscuro en la carc externa. Decorado con líneas verticalesincisas. SPV $95-111-32$

75- Fragmento Decorado. Pasta de regular calidad, basta, dura, con abundante descrasantes cuarcíticos de to dos bstomaños, chamotay particulas micaceas' superticie rugosa. Realizado a tometa. Cocción deficiente oxidante, con postcocción reductor color rojizo y grisáceo en la sección, beige en la cara internay negruzco y beige en la cara externa.Decorado con líneas verticalesincisas. SPV95-111-26

76- Fragmento Decorado. Pasta de regular caldad, dura, con abundantes y finos desgrasantes cuarcíticos y particulas micáceas; superficie nugosa. Realizado a tometo Cocción oxidante: color beige claro-blanquecino. Decorado con líneas verticales incisas. SPV95-111-23 


\section{O. REQUEJO PAGÉS}

77. Olla. diám: $18 \mathrm{~cm}$ Borde exvasado, labio redondeado, cuello corto y arranque de cuerpo globular. Pasta de regular calidad, con abundantes particulas cuarcíticas y chamota como desgrasantes. Realizada a torneta. Cocciónr oxidante y postcocción reductora deficiente: color beige muy claro, algunas zonas del cuello presentan tono ligeramente oblicuas, inclinadasa laderecha.

PM-1-84

78- Fragmento Decorado. Pasta fina, con finos desgrasantes cuarcíticos y partículas micáceas. Realizado a torneta. Cocción reductora: color grisáceo. Decoración incisa consistente en unaonda.

$\mathrm{PM}-2-84$

79. Fragmento Decorado. Pasta de regular calidad, con abundantes y finos desgrasantes cuarciticos y partículas micaceas. Realizado a torneta. Cocción reductora color blanquecino. Decoración incisa consistente en líneas oblicuas, inclinadas a la izquierda, , anchasy profundas, cortadas por líneas horizontoles

PM-5-84

80- Olla. diám. indeterminado. Borde vertical y labio redondeado. Pasta de regular calidad, con finos desgrasantes cuarcíticos y particulas micáceas. Realizado a torneto

coocion

81- Olla. diám: $18 \mathrm{~cm}$ Borde exvasado, labio redondeado y arranque de cuerpo globular. Pasta de bastante buena calidad, blanda, con finos desgrasantes cuarciticos Realizada a tometa. Cocción reductora: color grisćceo. Decoración en el arranque de cuerpo, consistente en trazos incisos horizontales yoblicuostoscamente trazados. P20

LP-21-83

82- Borde de Jarra. diám.: $13 \mathrm{~cm}$ Borde vertical, ligeramente exvasado y, labio recto. Pasta de regular colidad fina con desgrasantes cuarcíticos y micáceos Realizada a torneta cocción neductora deficiente: colorgrisenla seccióny rojzo en ambas caras. LP-39-83

83- Borde. diám. indeterminado. Borde vertical y labio recto. Pasta de mala calidad, con abundantes y groseros desgrasantes cuarciticos y partículas micćceas; superficie rugosa. Realizado atorneta. Cocción oxidante: color rojizo.

LP-40-83

84- Fragmento Decorado. Pasta de regular calidad, granulosa, con abundantes V micáceas Reclizado a torneta. Cocción reductora: color banquecino. Decoración incisa consistente en líneas verticales cortadas por líneas horizontales, formando reticula. LP-10-83

85- Fragmento Decorado. Pasta de regular calidad, granulosa, con abundantes desgrasantes cuarćlicos de pequeño y mediano tamaño y particulas micáceas Realizado a torneta. Coccion oxidante: color blanquecino. Decoración incisa consistente LP-9-83

86- Fragmento Decorado. Pasta de regular calidad, granulosa, con abundantes desgrasantes cuarć́ticos de pequeño y mediano tamaño y particulas micáceas Realizado a torneta. cocción oxidante: color blanquecino. Decoración incisa consistente en líneas verticales que cortan otras trozadas en sentido horizontal. LP-8-83

87. Fragmento Decorado. Pasta de regular callidad, blanda, con desgrasantes cuarcíticos y micáceos Realizado a torneta. Cocción reductora: color grisáceo Decoración incisa, consistente en líneas horizontales cortadas por otras oblicuas, inclinadasa la izquierda

LP-13-83

88- Fragmento Decorado. Pasta de regular calidad, dura y de sonido metálico, con escasos desgrasantes. Realizado a torneta. Cocción reductora: color gris. Decoración incisa consistente en líneas verticales cortadas por trazos horizontales. LP.14-83

89- Fragmento Decorado. Pasta de regular calidad, con escasos desgrasante Realizado a tometa. Cocción oxidante: color rosado. Decoración incisa consistente en trazosy lineas horizontales. Conserva restos de pintura azulada en la cara externa LP-36-8

90- Asa. Asa de cinta, con depresión central. Pasta de regular calidad, blanda, con desgrasantes cuarcíticosy micáceos. Cocción reductora: color grisáceo.
Lámina XIII: Peña Manil (Cebia - Cangas de Onís)
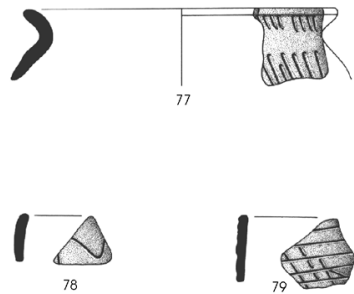

78

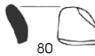

Lámina XIV: La Porra (Següenco - Cangas de Onís)

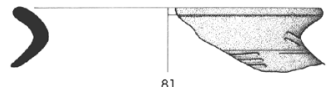

1

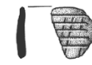

84
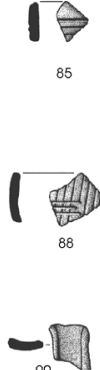

87 $\square \square$

83

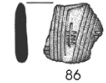

$\sqrt{5}$
90 


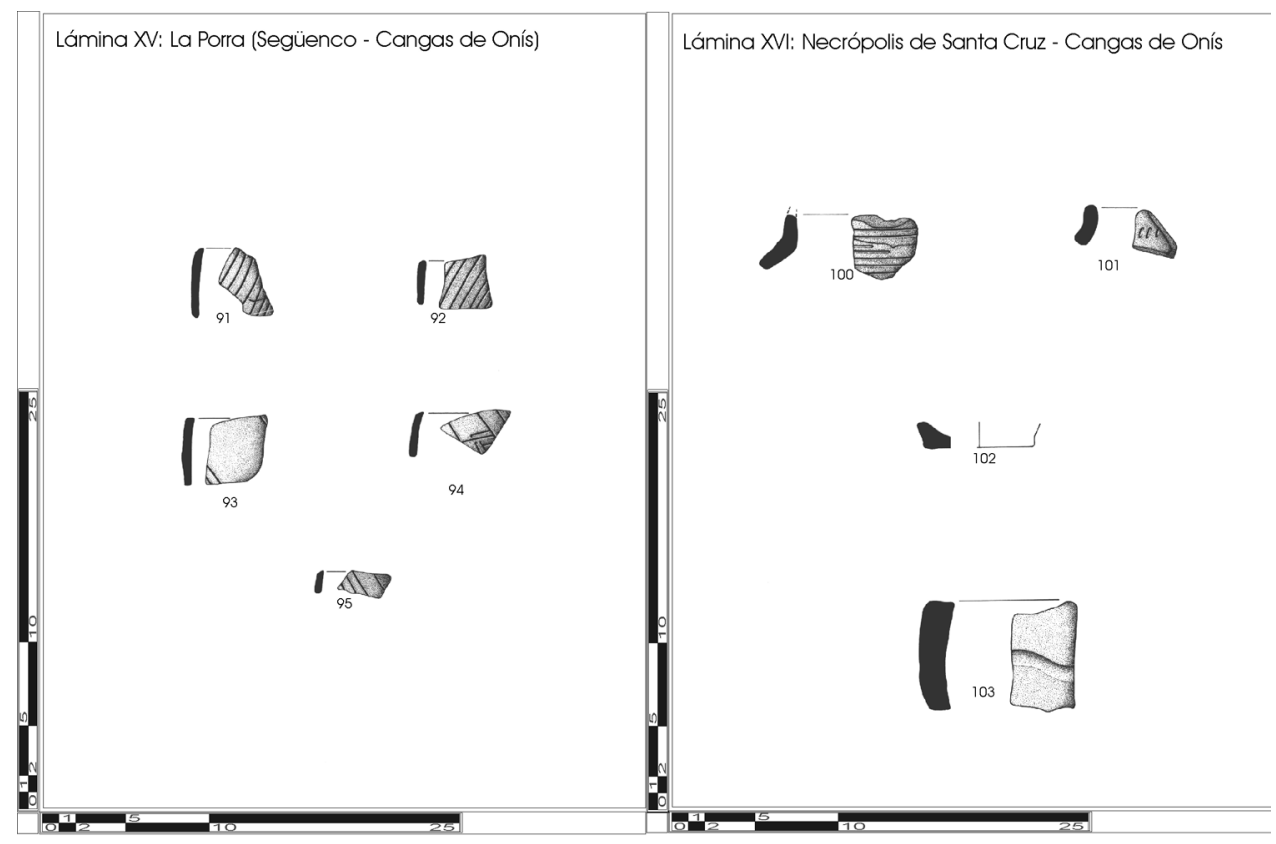

91. Fragmento Decorado. Pasta de bastante buena calidad, con escasos desgrasantes. Realizado a torneta. Cocción reductora: color grisáceo. Decorado con estrias horizontales

92. Fragmento Decorado. Pasta de buena calidad, con escasos desgrasantes. Realizado a tometa. Cocción reductora: color gris. Decorado con estrías horizontales (el Realizado a tometa. Cocción reduct
dibuj estáeróneamente horientado)

LP-2-83 93. Fragmento Decorado. Pasta de bastante buena calidad, con escasos
desgrasantes, Realizado a tometa. Cocción recuctora: colbr grisáceo. Decoración incisa consistente en dos líneas oblicuas, inclinadas a la derecha.

LP-3-83

94- Fragmento Decorado. Pasta de bastante buena calidad, fina, con escasos desgrasantes. Realizado a fometa. Cocción reductora: color grisáceo. Decoración incisa consistente en líneas horizontales cortadas por otras oblicuas, inclinadas a la derecha
LP-6-83

95- Fragmento Decorado. Pasta de regular calidad, fina, con escasos desgrasantes. Realizado a tometa. Cocción reductora: color grisáceo. Decorado con estrías horizontales (el dibuj está erróneamente horientado)

LP-7-83
100- Fragmento de Olla: cuello y arranque de cuerpo. Pasta de regular calidad dura, con abundantes desgrasantes cuarcíticos. Realizado a torneta; acabado defectuoso, presenta señales de espatulado. Cocción reductora: color grisáceo. Decoración incisa enel arranque del cuerpo, consistente en lineas horizontales, poco marcadas.

107. Olla diám. indeterminado. Borde ligeramente exvasado y Labio redondeado. Pasta de regular calldad, dura, con finos desgrasantes cuarciticos; superficie rugosa Realizada a torneta. Coccion oxidante, postcocción reductora: color beige en sección y cara interna y grisáceo en la cara extema. Decoración incisa, en el cuello, consistente en estrías verticales trazadas con peine. Restos de pinturanegra en el borde. SC-2-88: Catay, Nivel llo

102- Base. diám: $6 \mathrm{~cm}$ Base plana y paredes oblicuas abiertas. Pasta de regular caldad, blanda, ligera y algo porosa, con abundantes desgrasantes cuarcíticos partículas micaceas; superficie nugosa. Realizada a tometo. Coccion reductora: color gris claro, más oscuro en la sección. Presenta huellas evidentes de contacto con el fuego

103. Fragmento de Teja Decorada con motivo de onda realizado con la yema de los dedos. Pasta de calidad regular con desgrasantes cuarcíticos de pequeño tamaño. Cocción reductora: color grisáceo

SC-35-88: Catay, Nivel Ilc 


\section{O. REQUEJO PAGÉS}

Lámina XVII: Necrópolis de Santa Cruz - Cangas de Onís
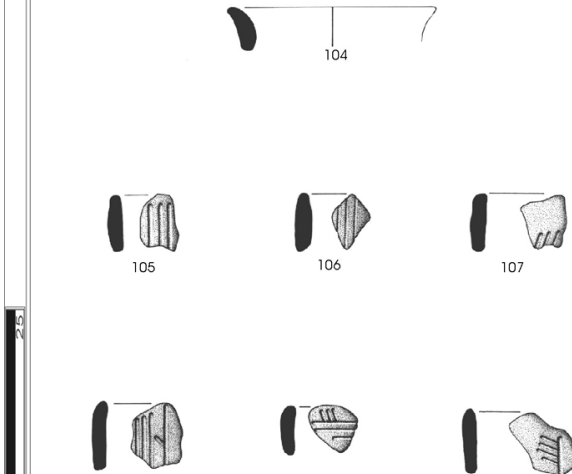

108

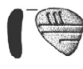

109

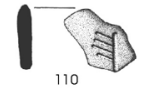

110
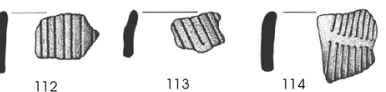

113
104- Olla. Diam: $12 \mathrm{~cm}$ Borde ligeramente exvasado y labio redondeado. Fasta de regular calidad, blanda, ligera, con abundantes desgrasantes cuarć́ticos de pequeño y mediano tamaño: superficie rugosa. Realizada a tometa. Cocción reductora: color gris SClaro. 105- Fragmento Decorado. Fasta de regular calidad, dura y de sonido metálico, con abundantes desgrasantes cuarcificos de pequeño y mediano tamaño; superficie rugosa. SC-30-88: Catay, Nivellle

106- Fragmento Decorado. Pasta de regular calidad, blanda, con abundantes desgrasantes cuarcíticos; superficie rugosa. Realizado a torneta. Cocción reductora: color gris claro en la sección y más oscuro en ambas caras, casi negruzco en el exterior. Decoración incisa consistente en estrías verticales, trazadas con peine. SC-21-88: Catay, Nivelllo

107- Fragmento Decorado. Pasta de regular calidad, dura y de sonido metálico, con abundantes desgrasantes cuarcíticos; superficie rugosa. Realizado a torneta. Cocción reductora deficiente: color gnisaceo-blanquecino. Decoración incisa consistente en estrías, ligeramente inclinadas a la derecha, trazadas superficialmente con peine.
SC-15-88: Catay, Nivel lic

108- Fragmento Decorado. Pasta de regular calidad, dura, con abundantes desgrasantes cuarćlícos de pequeño y mediano tamaño. Realizado a torneta; presenta huelas destil la

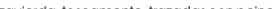
izquierda, toscamente traz 109- Fragmento Decorado. Pasta de regular calidad, blanda, ligera y algo porosa, con
desgrasantes cuarcíicos de pequeño y mediano tamaño y particulas micaceas. Realizado a torneta. Cocción reductora: color grisáceo. Decoración incisa consistenteen estrías horizontales que cortan a trazos incisos inclinados a la izquierda, trazados a peine. SC-10-88: Catay, Nivellic

110- Fragmento Decorado. Pasta de regular calldad, porosa, blanda, ligeray arenosa, con finos desgrasantes cuarcíticos y escasas partículas micáceas. intema. Conserva restos de lo que parece engobe en la cara extema. Decoración incisa consistente en estrías horizontales, oblicuas, inclinadas a la izquierda, contadas por una

SC-3-88: Catay, Nivel lle

111- Fragmento Decorado. Pasta de regular calidad, blanda, ligera y algo porosa, con desgrasantes cuarcíficos de pequeño y mediano tamaño y partículas micáceas. (Teashorizoniclestrazadas con peir

112- Fragmento Decorado. Pasta de regular calidad, dura, con abundantes desgrasantes cuarćíticos de pequeño y mediano tamaño; superficie nugosa. Realizado a tometa. exterior debido probablemente al contacto con el fuego. Decoración incisa consistente enestrias verticalestrazadas con peine.

SC-22-88: Catay, Nivelllc

113- Fragmento Decorado. Pasta de regular calidad, con abundantes desgrasantes cuarćíticos de pequeño y mediano tamaño: superficie rugosa. Realizado a tometa. Cocción oxidante: color anaranjado-rosáceo. Decoracion incisa consistente en estrias oblicuas, inclinadas a la izquierda, trazadas con peine. P16

SC-19-88: Catay, Nivelllo

114- Fragmento Decorado. Pasta de regular calidad, ligera y algo porosa, con desgrasantes cuarcíticos de pequeño y mediano tamaño y finas particulas micáceas. Realizado a torneła. Cocción reductora: color grisáceo. Decoración incisa consistente en

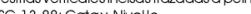




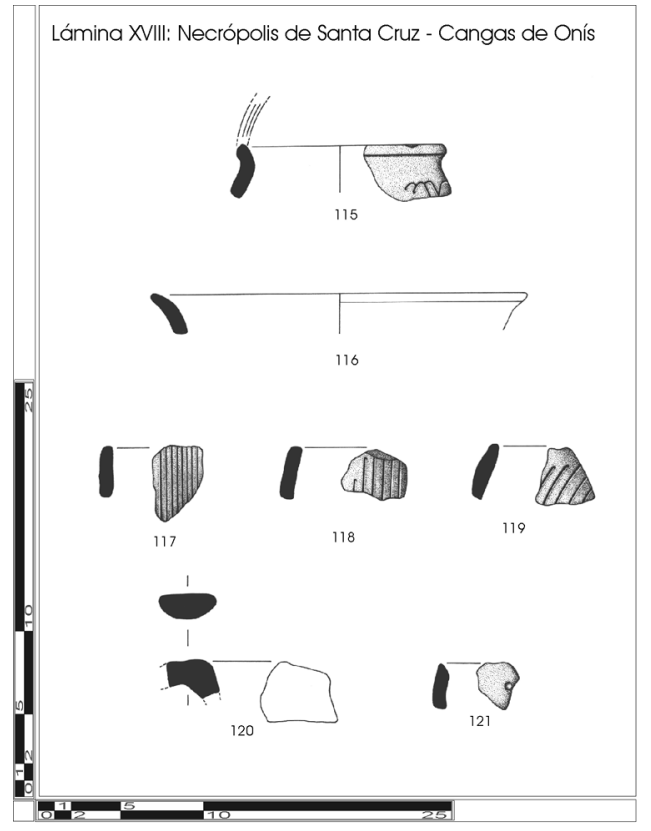

115- Olla. diám: $12 \mathrm{~cm}$. Borde ligeramente exvasado, labio redondeado. Pasta fina de buena calidad, ligera, porosa, con abundantes y finos desgrasantes cuarcíticos: superficie rugosa. Realizada a tometa. Cocción reductora: color gris. Decoración incisa. enel arranque del cuerpo, consistente en líneas onduladas entrecruzadas.

SC-13-88: Catay, Interior Tumbas

116- Olla diám: $22 \mathrm{~cm}$. Borde exvasado, curvo y labio redondeado, ligeramente apuntado.. Pasta de regular calidad, ligera y algo porosa, con desgrasantes cuarcíticos de pequeno y mediano tamaño y partículas micáceas. Realizada a torneta. Cocción reductora: color grisaceo.

SC-14-88: Catay, Interior Tumbas

117. Fragmento Decorado.. Pasta de regular colidad, blanda, ligera y algo porosa, con abundantes deggrasantes cuarcíticos de todos los tamaños y partículas micáceas superficie rugosa. Realizado a tometa. Coccion reductora: color gris claro, mas oscuro en la sección. Decoracionincisa consistenteenestrias verticales trazadas con peine.

118- Fragmento Decorado. Pasta de regular colidad, blanda, con abundantes desgrasantes cuarcílicos de todos los tamanos, superlicle lugosa. Realzado a torneta negruzco en el exterior. Decorción incisa consistente enestrís verticales. trazadas con peine.

119- Fragmento Decorado. Pasta de regular calidad, dura y de sonido metálico, con abundantes desgrasantes cuarcíticos de pequeño y mediano tamaño y alguna intrusión más grosera: superticie rugosa. Realizado a torneta. Cocción reductora: color grisáceo. Decoración incisa consistente en lineas oblicuas, inclinadas a la derecha, trazadas a

SC-17-88: Catay, Interior Tumbas

120- Borde. de jarra: diám, indeterminado.. Presenta arranque de asa en el labio Desarrollo vertical y sección semicircular. Pasta de mala calidad, algo porosa, con abundantes desgrasantes cuarciticos de todos los tamaños; superficie rugosa. Realizado a torneta. Coccion reductora de iliciente: color gris-beige en la cara externay negruzco en lainterna

121. Fragmento Decorado. Pasta de regular calidad, blanda, con abundantes 121- Fragmento Decorado. Pasta de regular calidad, blanda, con abundantes
desgrasantes cuarcíticos de todos los tamaños; superficie rugosa. Realizado a torneta cosgrasantes cuarciticos de todos los tamaños; superficié rugosa. Realizado a torneta. negruzco en el exterior. Decorado con un punto inciso trozado a punzón. SC-25-88: Cota y. Interior Tumbo 